\title{
WestVirginiaUniversity
}

THE RESEARCH REPOSITORY @ WVU

Graduate Theses, Dissertations, and Problem Reports

2011

\section{From Canal Boats to Canoes: The Transformation of the C\&O Canal, 1938--1942}

Angela Sirna

West Virginia University

Follow this and additional works at: https://researchrepository.wvu.edu/etd

\section{Recommended Citation}

Sirna, Angela, "From Canal Boats to Canoes: The Transformation of the C\&O Canal, 1938--1942" (2011). Graduate Theses, Dissertations, and Problem Reports. 808.

https://researchrepository.wvu.edu/etd/808

This Thesis is protected by copyright and/or related rights. It has been brought to you by the The Research Repository @ WVU with permission from the rights-holder(s). You are free to use this Thesis in any way that is permitted by the copyright and related rights legislation that applies to your use. For other uses you must obtain permission from the rights-holder(s) directly, unless additional rights are indicated by a Creative Commons license in the record and/ or on the work itself. This Thesis has been accepted for inclusion in WVU Graduate Theses, Dissertations, and Problem Reports collection by an authorized administrator of The Research Repository @ WVU. For more information, please contact researchrepository@mail.wvu.edu. 


\title{
From Canal Boats to Canoes: The Transformation of the C\&O Canal, 1938-1942
}

\section{Angela Sirna}

\author{
Thesis submitted to the \\ Eberly College of Arts and Sciences \\ at West Virginia University \\ in partial fulfillment of the requirements \\ for the degree of \\ Master of Arts \\ in \\ History \\ with an emphasis in Public History \\ Melissa Bingmann, Ph.D., Chair \\ Ken Fones-Wolf, Ph.D. \\ Larry Sypolt, M.A. and M.L.I.S \\ Department of History \\ Morgantown, West Virginia \\ 2011
}

Keywords: Chesapeake \& Ohio Canal, National Park Service, Historic American Buildings Survey, Civilian Conservation Corps,

Public Works Administration, Historic Preservation 


\section{ABSTRACT \\ From Canal Boats to Canoes: The Transformation of the C\&O Canal, 1938-1942}

\section{Angela Sirna}

I have come to understand the Chesapeake \& Ohio Canal as two different entities, both of which occupy the same geographic space. The first is a nineteenth century transportation system that impacted thousands of people in the Potomac River Valley. The second is the reincarnation of the first as a National Historical Park. The first is a busy, messy, and noisy landscape. The second serves as a refuge for the urban masses, and only faintly resembles its predecessor. This thesis seeks to understand how one evolved into the other.

Upon further inspection, one discovers that C\&O Canal National Historical Park balances a precarious equilibrium of three competing efforts: historic preservation, natural preservation, and recreational development. The challenge is to understand how these visions emerged, transformed the landscape, and reflect changing social, political, and cultural forces.

The transformation of the C\&O Canal did not occur overnight, but over the course of several decades. I focus on the period 1938 to 1942, when the federal government initially purchased the canal and New Deal relief workers focused on rewatering the first 22 miles of the canal. I approach the preservation of the canal as mode of cultural production to gain a deeper understanding of how the park looks and functions today.

During the New Deal era, the federal government became involved in the historic preservation field and emerged as its leader under the auspices of the National Park Service. The C\&O Canal offers a useful case study for early federal historic preservation efforts, and shows how social, cultural, and political movements of the time transformed the canal into a park. 


\section{ACKNOWLEDGEMENTS}

Just as the C\&O Canal was shaped by many hands, I feel this thesis, too, was shaped by several individuals who deserve a note of gratitude. First, I must thank Sam Tamburro, Cultural Resource Program Manager at C\&O Canal National Historical Park, who stole me from the ranks of seasonal interpretive rangers and put me to work in the park's cultural resource program. He encouraged me to pursue this topic as a thesis and willingly served as a sounding board for my ideas. I also thank my advisor and committee chair, Dr. Melissa Bingmann, who has been incredibly supportive through the entire process and helped improve the final draft considerably. Dr. Ken Fones-Wolf and Larry Sypolt also graciously read my work, and provided useful insight. I am indebted to Larry, who generously opened his own personal Civilian Conservation Corps library to me.

I specially thank my parents, David and Dot Sirna. Their support for my pursuit in a career in history has never flagged. They patiently listened when I debated the different Social Studies Fair project ideas in grade school, and on through when I weighed my options for graduate school. They never blinked an eye when I told them I was going to spend my summer interning for the National Park Service on a canal boat, or that I had decided to write a master's thesis when it was not required for my program. Perhaps I need to find new ways to shock them. I also thank my siblings, friends, and colleagues for keeping me sane throughout the process by providing much needed mental breaks and keeping me smiling. 


\section{Table of Contents}

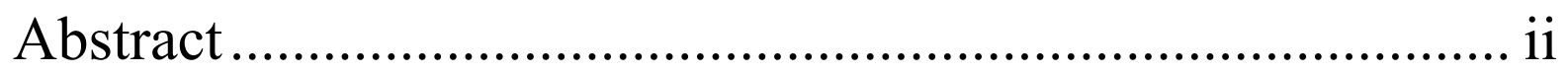

Acknowledgements ...................................................... iii

Chapter One: Introduction .............................................. 1

Chapter Two: A Perfect Storm …..................................... 8

Chapter Three: C\&O Canal—A Case Study ........................25

Chapter Four: The Men in Green.......................................61

Chapter Five: Conclusion ............................................... 83

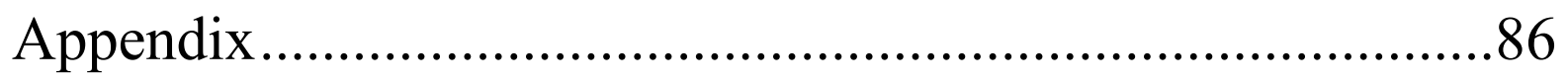

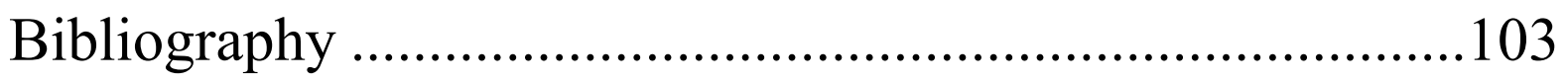




\section{CHAPTER ONE}

\section{Introduction}

The federal government became increasingly involved in the preservation of historic sites during the New Deal era, marking a significant turning point in the historic preservation field. Before, historic preservation was mostly a community movement advocated by elite women, but the Roosevelt administration found utility in preservation for forging an American identity. During this period, the National Park Service (NPS) expanded east of the Mississippi River and turned its focus to include historic sites rather than just wilderness areas. By the end of the decade, the federal government emerged as the leader in historic preservation under the auspices of the NPS. The preservation of the Chesapeake \& Ohio Canal between 1938 and 1942 serves as a useful case study for this early period in federal historic preservation efforts. The challenge to preserve the defunct transportation system as a recreational park shows tension between three competing visions: the preservation of cultural resources, the preservation of the canal's natural qualities, and development of recreational potential. During its operation, the canal was a busy, messy place that provided the livelihood of thousands of people. The NPS took the C\&O Canal away from its historic appearance and function to create a refuge for the urban masses.

Construction of the C\&O Canal began in 1828, during the height of the American canal era, and ended in 1850. It follows the Potomac River from Georgetown to Cumberland, Maryland. The C\&O Canal Towage Company abandoned the canal after a flood in 1924 . The National Capital Park and Planning Commission used the Great Depression and the New Deal as an opportunity to create a new identity for the 96 -year old canal. The B\&O Railroad was pressured to sell the canal because of the deteriorating economy, and President Franklin Delano 
Roosevelt's New Deal programs provided the necessary manpower and funds to transform the abandoned transportation system into a recreational waterway. The initial preservation efforts from 1938 to 1942 focused on rewatering the first 22 miles of the canal. New Deal relief workers rehabilitated the canal prism, towpath, and locks, and repaired several lockhouses and Great Falls Tavern. The choices of what to change, what to preserve, how to change it, and how to preserve it, were crucial decisions made during this period, and constructed a vision for the C\&O Canal National Historical Park that was fundamentally different from C\&O Canal the transportation system.

NPS Historians Harlan Unrau and G. Frank Willis examine this particular period of NPS expansion and development of the historic preservation field in Expansion of the National Park Service in the 1930s: An Administrative History, and in “To Preserve the Nation's Past: The Growth of Historic Preservation in the National Park Service during the 1930s." ${ }^{.1}$ Their work provides an essential administrative history of the growth of the NPS and its entry into historic preservation during the New Deal. They assert that the $\mathrm{C} \& \mathrm{O}$ Canal was one of the first historical park programs where research was tied closely to its development. My case study builds directly upon their assertion, expands the historical context, and links historic preservation to the efforts of the Civilian Conservation Corps.

NPS Historian Barry Mackintosh wrote $C \& O$ Canal: The Making of a Park, which serves as an invaluable administrative history of the park. His work begins with the federal government's acquisition of the canal in 1938, and moves through the establishment of the C\&O

\footnotetext{
${ }^{1}$ Harlan Unrau and G. Frank Willis, Expansion of the National Park Service in the 1930s: An Administrative History (Denver: Department of Interior, National Park Service, 1983), accessed September 17, 2010, http://www.cr.nps.gov/history/online books/unrau-willis/adhi.htm, and Harlan Unrau and Frank Willis, "To Preserve the Nation's Past: The Growth of Historic Preservation in the National Park Service During the 1930s," The Public Historian 9, 1987.
} 
Canal National Historical National Park in 1971. He discusses subsequent management decisions prior to the 1990s, when his book was published. This thesis seeks to contribute to Mackintosh's work by analyzing the first preservation efforts and how they reflected larger cultural forces of the period. It also outlines the struggle of park planners to strike a balance between historic preservation, natural conservation, and recreation potential. By doing so, we gain a much richer understanding of why the canal as a park looks and functions as it does today. ${ }^{2}$

This thesis is derived from my understanding of public history as a mode of cultural production. My methodology has been informed by Domesticating History: The Political Origins of America's House Museums by Patricia West, The Lowell Experiment: Public History in a Postindustrial City by Cathy Stanton, and Politics of Public Memory: Tourism, History, and Ethnicity in Monterey, California by Martha Norkunas. All three monographs look at historic sites and landscapes as cultural texts. They view preservationists and interpreters as cultural performers, whose decisions are influenced by their time period and sensibilities. Patricia West charts the historic house museum movement and historic preservation in her work through a series of case studies. She argues that when a house becomes a museum, its function fundamentally changes. The purpose of which a building is preserved and interpreted is significantly shaped by political and cultural forces. Cathy Stanton takes an anthropological approach to examining preservation decisions and interpretation practices at Lowell National Historical Park. She asserts that the National Park Service created the park in the 1970s to use heritage tourism and urban renewal to stimulate Lowell's declining economy. She fears, however, that the park's story of continuing progress masks the ugly realities of economic

\footnotetext{
${ }^{2}$ Barry Mackintosh remains the authority of the administrative history of the C\&O Canal, since he gives a long term projection of the making of the park. See Barry Mackintosh, C\&O Canal: The Making of a Park (Washington, D.C.: National Park Service/Department of the Interior, 1991).
} 
changes, particularly the process of deindustrialization. Martha Norkunas examines the politics

of heritage tourism in her case study on historical attractions in Monterey, California. She discovers that the interpretation of the city's historic sites is distorted to appeal to the upper class population, who constitute most of the tourist audience. ${ }^{3}$

The second chapter is largely a contextual piece that attempts to reconcile several different cultural movements, including historic preservation, natural conservation, tourism, and recreation. All of these forces intersected within the context of the Great Depression and an expanding federal government through New Deal legislation. At first glance, these movements may seem incredibly disparate and unrelated but they overlapped and ultimately shaped the C\&O Canal as a park. This chapter discusses the urgency to create relief programs during the Great Depression and a general uncertainty in America's progress. It explores Franklin Delano Roosevelt's conservation ethic, and how it shaped significant New Deal programs. ${ }^{4}$ I also discuss the concurrent expansion of the NPS east of the Mississippi River, and the emerging NPS History Program. ${ }^{5}$ This expansion of both the NPS and its History Program resulted in the federal government (through the NPS) becoming the leading authority in the historic preservation movement. The expansion of the NPS during this time reflects a desire to create

\footnotetext{
${ }^{3}$ Patricia West, Domesticating History: The Political Origins of America's House Museums (Washington, D.C.: Smithsonian Institution Press, 1999); Cathy Stanton, The Lowell Experiment: Public History in a Postindustrial City (Amherst: University of Massachusetts Press, 2006); Martha Norkunas, The Politics of Public Memory: Tourism, History, and Ethnicity in Monterey, California (Albany: State University of New York Press, 1993).

${ }^{4}$ I consult Anne Riesch Owen and Neil Maher heavily for grasping this aspect of conservation history. See A.L. Riesch Owen, Conservation Under F.D.R. (New York: Praeger, 1983), and Neil Maher, Nature's New Deal: The Civilian Conservation Corps and the Roots of the American Environmental Movement (Oxford: Oxford University Press, 2008).

${ }^{5}$ See Harlan Unrau and G. Frank Williss, Expansion of the National Park Service in the 1930s: An Administrative History and "To Preserve the Nation's Past: The Growth of Historic Preservation in the National Park Service During the 1930s." Also, Denise Meringolo's work on the professionalization of public history in the Park Service during this period has been extremely valuable in understanding changing historical thought in the field. See Denise D. Meringolo, "Turning Nature into History: The Professionalization of Public History in the National Park Service During the 1930s," Dissertation-George Washington University, 2005.
} 
recreational opportunities for an increasingly urban public. It also reflects trends in American tourism, which fostered American nationalism. From 1880 to 1940, the tourist industry in the United States promoted the experience of seeing certain sites as being distinctly "American.,"6

The third chapter approaches the $\mathrm{C} \& \mathrm{O}$ Canal as a case study in historic preservation for this early period of federal historic preservation efforts. I describe the state of the canal as it sat abandoned after the 1924 and 1936 floods, when it was acquired by the federal government at a bargain price of $\$ 2.5$ million. ${ }^{7}$ I further relate the formalization of the canal as a recreational entity. This large-scale implementation of adaptive reuse transformed the historical landscape of the $\mathrm{C} \& \mathrm{O}$ Canal into a radically different vision to meet society's needs and sensibilities. I describe the contributions of Historic American Building Survey architects, historians, and landscape architects at the canal, which reflect the general maturation and professionalization of the historic preservation field in the NPS. I also discuss the contributions of New Deal workers, particularly the Civilian Conservation Corps, which provided unskilled labor, and the Public Works Administration, which provided skilled labor.

The fourth chapter details the contributions of the two African American Civilian Conservation Corps companies that provided the necessary manpower for the preservation projects. ${ }^{8}$ Very few CCC scholars acknowledge the contributions of the corps to the historic preservation field, mostly because enrollees are fondly recalled as "Soil Soldiers" in

\footnotetext{
${ }^{6}$ Marguerite Shaffer, See America First: Tourism and National Identity, 1880-1940 (Washington, D.C.: Smithsonian Institution, 2001).

${ }^{7}$ Legally, the canal was not "abandoned" during this period. To avoid foreclosure after the 1924 flood, the company had to prove that the canal was not abandoned and the courts accepted the position that the canal "was merely suspended temporarily in the absence of remunerative business." Mackintosh calls this "ludicrous," because the canal was in such a condition that it could not easily be put back in working order, and in all reality, the canal was indeed abandoned. See Mackintosh, 2; Walter Sanderlin, The Great National Project: A History of the Chesapeake and Ohio Canal (Baltimore: John Hopkins Press, 1946), 254-67.

${ }^{8}$ Camps were MD-NP-1 and MD-NP-2 and were occupied by CCC companies 325 and 333.
} 
"Roosevelt's Tree Army" for their significant accomplishments in environmental conservation. ${ }^{9}$ I argue against Denise Meringolo's assertion that CCC enrollees were only a test audience for new NPS public historians, but that they were integral in bringing the canal to life for visitors. This chapter is significant, too, for detailing two little known African American CCC companies. ${ }^{10}$ Without oral histories or memoirs, it is virtually impossible to provide a near complete picture of the two camps. However, material found at the National Archives and the fortunate find of two surviving copies of the camp newspapers reveal a partial view. This material combined with secondary source material provides a larger understanding of these two camps, especially in understanding the issues of desertion in the $\mathrm{CCC}$ and education. ${ }^{11}$

This thesis contributes to various fields including public history, historic preservation, environmental history, and twentieth century United States history. First, it contributes to the understanding of the $\mathrm{C} \& \mathrm{O}$ Canal National Historical Park, and why it looks and functions the way it does, by treating its preservation as a cultural production. Second, it is a case study in

\footnotetext{
${ }^{9}$ For a general history of the CCC, I often turn to Neil Maher, but he does not acknowledge the CCC's contributions for historic preservation work. I borrow the terms "Soil Soldiers" and "Roosevelt's Forest Army" from titles to other CCC histories. See Leslie Alexander Lacy, The Soil Solders: The Civilian Conservation Corps in the Great Depression (Radnor, Pennsylvania: Chilton Book Company, 1976), and Perry Merrill, Roosevelt's Forest Army: A History of the Civilian Conservation Corps (Montpelier: Perry H. Merrill, 1981).

${ }^{10}$ Little is known about these two particular African American companies, and little has been done to look at them critically. While Barry Mackintosh acknowledges the physical work carried out by the enrollees, he barely acknowledges that they were African American and they were segregated. To be fair, to do so would have been beyond Mackintosh's scope. Additionally, a recent National Capital Region study researched the various camps in the region to discern if there were any cultural resources left that should be considered for preservation. This study included the two camps at the C\&O Canal, and gives brief descriptions of the camp building, work undertaken, and a little about camp life. Being a cultural resource study, it hardly suffices to fulfill the desire for a longer narrative, but gives a useful starting point. See L. P. Davidson and J. A. Jacobs. "Civilian Conservation Corps Activities in the National Capital Region of the National Park Service". (Washington, D.C.: Department of the Interior, National Park Service, 2005).

${ }^{11}$ In general, scholarship on African Americans in the Civilian Conservation Corps is limited. Olen Cole provides the sole monograph on the subject. His contributions are limited because his research is focused on camps in California performing environmental conservation work. See Olen Cole, Jr., The African-American Experience in the Civilian Conservation Corps (Gainesville: University Press of Florida, 1999). Also, Alfred Cornebise provides a useful chapter to African Americans in his book about the CCC newspapers. See Alfred Emile Cornebise, The CCC Chronicles: Camp Newspapers of the Civilian Conservation Corps, 1933-1942, (Jefferson, North Carolina: McFarland \& Company, 2004). Neil Maher, too, discusses African Americans in his work.
} 
early federal government involvement in historic preservation through the National Park Service during the Great Depression. Third, it credits the Civilian Conservation Corps as an integral contributor to the historic preservation movement, while showing how it differed from present notions of preservation. Finally, it details two little known African American CCC companies and how their experiences fit into wider stories about the $\mathrm{C} \& \mathrm{O}$ Canal, the $\mathrm{CCC}$, and historic preservation. 


\section{CHAPTER TWO}

\section{A Perfect Storm}

Landscapes are not shaped purely through ecological or geologic forces, but social, political, and cultural forces as well. Looking at the transformation of the C\&O Canal into a National Historical Park requires an examination of greater historical changes occurring within the cultures that altered the landscape. ${ }^{12}$ Therefore, this chapter explores the larger context of the Great Depression era, where the country was thrown into a whirlwind of anxiety, uncertainty, and desperation that lasted for a decade. Americans looked for change and hope when they elected Franklin Delano Roosevelt as President in November 1932. FDR brought with him not only a range of experience and a cadre of ideas, but a distinct progressive conservation philosophy, which shaped some of his key New Deal programs, such as the Civilian Conservation Corps, Public Works Administration, Works Progress Administration, and Historic American Building Survey. During FDR's administration, the National Park Service expanded west of the Mississippi River and broadened its mission from natural preservation to include historic preservation. FDR and NPS sponsored a concerted effort to create recreational facilities in rural settings for an increasingly urban public. The desire to preserve historic sites reveals the government's desire to create a nostalgic American identity—one in which Americans could look towards the past to find hope for the future.

\footnotetext{
${ }^{12}$ Neil Maher discusses in depth how the cultural forces of the New Deal and CCC transformed public landscapes. Phoebe Cutler also examines these cultural forces and their impacts on a variety of public works projects. See Neil Maher, Nature's New Deal: The Civilian Conservation Corps and the Roots of the American Environmental Movement (Oxford: Oxford University Press, 2008), 6-7. See also Phoebe Cutler, The Public Landscape of the New Deal (New Haven: Yale University Press, 1985).
} 
The debilitating effects of the Great Depression on the American psyche made it ripe for political change. The country elected Democrat Franklin Delano Roosevelt on November 8, 1932, ushering in a new era for the Democratic Party that took effect upon FDR's presidential inauguration in March 1933. Roosevelt's First Hundred Days proved critical as he immediately called for legislation to stop the bleeding economy, although historian Anthony Badger believes Roosevelt and his administration were vastly underprepared to handle the crisis. ${ }^{13}$ Congress passed sixteen pieces of legislation, including the Agricultural Adjustment Act, which regulated what farmers could and could not plant; the National Recovery Administration, which set minimum prices and wages; the Public Works Administration, the largest public works program; and the Federal Emergency Relief Administration, which provided emergency relief for thousands of people.

On March 31, 1933, only seventeen days after FDR took office, congress passed the Emergency Conservation Work Act (ECW), which effectively created the Civilian Conservation Corps (CCC). This new program initially provided employment to 275,000 young men in 1,468 camps all across the country to work on over 62 different types of conservation projects. ${ }^{14}$ This program was administered by the Army and the departments of Labor, Agriculture, and Interior. Young men enrolled in camps for six month periods to undertake conservation work in parks and forests all over the country. When enrollees were not working, they had the opportunity to further their education and build new skills through classes offered at the camps. The program continued until 1942 and nearly 2.5 million men participated. This program reflected FDR's

\footnotetext{
${ }^{13}$ Anthony Badger, "The First Hundred Days and Beyond: What did the New Deal Accomplish?," The Historian's Perspective 19 (March 2009): accessed September 16, 2010, http://www.gilderlehrman.org/historynow/03 2009/historian3.php.

${ }^{14}$ Figures are from first six month enrollment period (April 1, 1933 to September 30, 1933). Maher, 45, 48, 82.
} 
strong conservationist sensibility that had developed over his career and ultimately affected his New Deal policies. ${ }^{15}$

Historian A.L. Riesche Owen asserts that FDR was a second generation progressive conservationist. He was not a spectacular conservationist like Theodore Roosevelt, but had a much broader technical knowledge and could tap into a cadre of well-trained specialists. He also had the support of established conservation organizations. This background gave him the ability to launch a large-scale federal program. FDR implemented conservation programs mostly to address the unemployment crisis, but it left a permanent legacy of the American peoples' responsibility for conserving the country's natural resources and managing public lands. ${ }^{16}$

FDR's background in conservation naturally stemmed from his association with Theodore Roosevelt and other prominent first generation conservationists like Gifford Pinchot and John Muir, who made conservation popular. This initial generation laid the foundations for modern environmentalism, by promoting the conservation of public lands, instituting new forestry practices, and conserving natural resources. John Muir later broke from other conservationists by promoting strictly preservationist ideas, which desired virtually no human intervention in the natural landscape. ${ }^{17}$ FDR identified more closely with the progressive conservationist ethic, where the dollar and cents aspect, coupled with environmental responsibility, appealed to his progressive sensibilities. He experimented with forestry practices at his home at Hyde Park and was anxious to share his discoveries with others to improve

\footnotetext{
${ }^{15}$ A.L. Riesche Owen, Conservation Under FDR (New York: Prager Publishers, 1983).

${ }^{16}$ Owen, vii and 3.

${ }^{17}$ According to Neil Maher, the Hetch Hetchy Valley incident in Yosemite National Park in 1913 describes the conservationist ideology of the early twentieth century and demonstrates two competing ideas. There was a controversy of whether or not to dam the valley to supply water to San Francisco. Gifford Pinchot supported the dam as an efficient use of the region's natural resources, while John Muir campaigned for the preservation of the valley as an "aesthetic and spiritual resource" for the public. Congress decided to dam the valley. See Maher, 4-6.
} 
surrounding lands. He instituted good silvacultural practices on his own 1,250 acre farm, including fire prevention, planting cut-over and poor farmland, and removing mature and undesirable trees. His 450 acre woodland tract consistently produced wood products, such as cordwood and cross ties, and he even sold Christmas trees. ${ }^{18}$

As a politician, FDR advocated conservation policies both in public speaking and in action. As a New York State Senator (1911-1913), he served as chairman of the New York Commission on Forests, Fish, and Game and worked with T.M. Obsborne, the state commissioner of forests. While Assistant Secretary of the Navy (1913-1920), FDR served as the New York delegate to the Conservation Congress and served as vice-president of the New York State Forestry Association. It was not until he was the governor of New York (1928-1932) that FDR was able to initiate statewide conservation legislation. It was during this time that FDR instituted policies that he later applied on the national scale, including state reforestation, land utilization, water power protection and development, and pollution control. He also initiated a program that used the unemployed for conservation work, which later proved valuable experience in formulating some of his New Deal programs. ${ }^{19}$

Although FDR believed in conservation to ultimately turn a profit in a responsible manner, he certainly exhibited a measure of sentimentality towards nature and recognized its recreational potential. This mostly stems for his love of nature that developed during childhood as he spent hours exploring the woods, horseback riding, and sailing. Owen relates a particular anecdote in which FDR instructed employees to repair and stabilize a badly damaged oak in front of the Roosevelt Library, because it was old and he used to play under it as a young boy.

\footnotetext{
${ }^{18}$ Owen, 5.

${ }^{19}$ Owen, 8-10.
} 
Here FDR acted upon sentimental memories and recognized the tree's contributions as a landmark. Additionally, after contracting polio, he had roads built in the woodlands around Hyde Park where he used to walk. ${ }^{20}$ In this instance, FDR acted upon his childhood sentimentality to alter nature to meet his changing needs. This similar ethic was replicated in national and state parks, forests, and Recreational Demonstration Areas (RDA) across the country in an effort to bring visitors closer to nature and beauty while inevitably altering the landscape.

FDR's sentimentalities towards nature are not especially remarkable, unless considered as part of a much longer western cultural tradition. Historian Simon Schama argues that western culture has deep ties and traditions associated with nature. His work, Landscape and Memory, offers a different viewpoint from many environmental historians who place mankind as the central reason for environmental degradation, especially in western capitalist culture where the Earth is seen as a machine that cannot be broken. Schama asserts that our landscape tradition is a product of a shared culture, one "built from a rich deposit of myths, memories, and obsessions." We naturally have an affinity for the primitive forest, the river of life, and the sacred mountain, because of these deep seeded traditions. ${ }^{21}$ These myths are reflected in the American pursuit of the "pastoral ideal," which romanticized American agrarian and natural landscapes. This ideal became especially pertinent during the nineteenth century when industrialization began to transform the landscape, or "the machine" entered "the garden." ${ }^{22}$ In the throes of the Great Depression, the American nostalgia for natural landscapes continued because they seemed to offer a remedy or a respite from the country's economic woes.

\footnotetext{
${ }^{20}$ Owen, 4-5 and 8.

${ }^{21}$ Simon Schama, Landscape and Memory (New York: Alfred A. Knopf, 1995), 9-14.

${ }^{22}$ See Leo Marx, The Machine in the Garden (Oxford: Oxford University Press, 2004).
} 
When FDR took office as President of the United States in 1933, he used the unemployment crisis as an opportunity to advance the federal government's involvement in conservation work. FDR needed labor intensive work to employ both skilled and unskilled labor. Reforestation, soil control, fire prevention, flood control, and other similar projects proved to be a good match for the labor crisis and the "youth problem." ${ }^{, 23}$ Such projects could potentially require thousands of man hours, but only temporarily, and would not result in a permanent workforce. It was a part of the "pump priming" initiative to indirectly stimulate the economy. Finding the manpower to undertake such projects was not an issue, since unemployment was estimated to be between 20 to 25 percent in 1933, or approximately 15 million people. FDR's administration turned to the Department of Agriculture, which included the National Forest Service, and the Department of the Interior, which included the National Park Service (NPS) to create and manage conservation projects working with New Deal relief programs. The Department of Agriculture was involved in many projects aimed at helping hard pressed farmers, bringing electricity to rural areas, and improving the nation's forests. The Department of Interior ran the Public Works Administration and was also responsible for the development of state and national parks.

The NPS was established in 1916, although the first national park, Yellowstone, was created by Congress in 1872. By 1929, there were twenty National Parks and thirty-two national monuments, for a total of 15,696 square miles. ${ }^{24}$ Before 1933 , almost all the areas of the NPS

\footnotetext{
${ }^{23}$ Adolescents' lack of unemployment and a viable future, coupled with idleness, during the period was a part of what some contemporaries called "America's Youth Problem."

${ }^{24}$ NPS historians Unrau and Williss wrote a compelling article about the expansion of the NPS during this period. See Harlan Unrau and G. Frank Williss, Expansion of the National Park Service in the 1930s: An Administrative History (Denver: Department of Interior, National Park Service, 1983), accessed September 17, 2010, http://www.cr.nps.gov/history/online books/unrau-williss/adhi.htm. For general National Park Service administrative histories, see Barry Mackintosh, The National Parks: Shaping the System. (Washington, D.C.:
} 
were contained west of the Mississippi River, reflecting its initial emphasis on protecting scenic natural areas. For about sixteen years, NPS Director Horace Albright worked to have all of the War Department's military parks, which were mostly east of the Mississippi, transferred to the NPS. This allowed the NPS to become a true national agency, while diversifying its inventory of scenic sites by interspersing those of historical significance, and to locate parks near the majority of the nation's population centers. After a meeting between Albright and FDR in 1933, the president agreed to the reorganization. However, Executive Order 6166 gave the NPS more than just the military parks. On August 10, 1933, eleven national military parks, two national parks, ten battlefield sites, ten national monuments, three miscellaneous memorials, and eleven national cemeteries were formally transferred to the Department of the Interior from the War Department. The same order also transferred fifteen national monuments from the Forest Service to the Interior. This reorganization nearly doubled the units administered by the NPS from 67 to 137 . The number of scenic areas slightly increased from 47 to 58 . However, the number of historic sites, which had been only a small contingent of the National Park System before 1933, nearly quadrupled from 20 to 77 . Over the next six years the NPS continued to expand by an additional seven natural areas, seventeen historic sites, and six recreation areas. ${ }^{25}$

The desire to locate national parks in reach of the major population centers in the east stemmed from two cultural movements that emerged before the Great Depression. First, the recreation movement promoted improvement of human resources through physical activity and play, and attached itself to New Deal conservation efforts as "human conservation." In the 1920s, for the first time in its history, the United States became a predominately urban society,

National Park Service, 1991), and William H. Sontag, National Park Service: The First 75 Years (Philadelphia: Eastern National Park and Monument Association, 1990).

${ }^{25}$ Unrau and Williss, Chapter 2. 
with over half the population living in cities rather than the countryside. Phoebe Cutler writes, "For such a newly urbanized citizenry, no garden and, for that matter, no baseball diamond could substitute for forest and field." FDR took the economic crisis as an opportunity to expand recreational opportunities in national forests, national parks, and in Recreation Demonstration Areas (RDA) - a new type of park specifically developed by the CCC. The purpose was to get people—particularly urban youth—out into the countryside to answer "the people's restless nostalgia for the woods," an ailment that developed with the country's industrialization. ${ }^{26}$ RDAs, such as Catoctin Mountain Park, were located outside urban areas or along major roadways. They usually offered camping, picnic shelters, and hiking trails that took visitors to natural areas or places with historic interest. These RDAs might have worked with existing natural surroundings or cultural resources, but were certainly a conscious development on the part of the landscape architects and workers who altered the landscape to fit the population's recreational needs.

The fact that RDAs were located along roadways outside urban areas is essential, since it directly reflects the second cultural movement-American tourism. Marguerite Shaffer explores how American nationalism was formed or supported through tourism as people sought to find American exceptionalism in the landscape in her work See America First: Tourism and National Identity, 1880-1940. In order to know America, one had to see and personally experience it through travel. Shaffer asserts that this movement first began in the 1880s with the establishment of national parks in the west. These parks were initially promoted by railroad corporations, and encouraged Americans to travel across the country in elegant style. At the turn of the century, train travel gave way to the automobile. The "Good Road movement" emerged to promote a

${ }^{26}$ Cutler, 50. 
network of improved roads to unite the country, increase mobility, and better life as a whole. ${ }^{27}$ New and improved roads were often given historical associations, such as Lincoln Highway, and pointed travelers to areas of historical interest to foster an American identity. During the New Deal, the Works Progress Administration's Federal Writers' Project produced guidebooks for forty-eight states, in which the federal government officially sanctioned tourism as a ritual of citizenship. These guides set out to identify unique and indigenous American culture in a populist narrative to "celebrate an inherent American culture across the landscape." 28

Shaffer's idea that tourism fostered American nationalism is also reflected in the NPS development of another kind of park during the New Deal— the parkway. This kind of a park was more than just a connector road between national parks, but was meant to capture manipulated historic and natural landscapes to project a larger American narrative. ${ }^{29}$ Traveling along these parkways was more than just getting from one destination to another; it was a journey through American space and time to give travelers optimism for the country's future. Planners established RDAs along these routes so motorists could take a break from driving, and to develop themselves physically, mentally, and spiritually. Both the Blue Ridge Parkway and George Washington Memorial Parkway are two such examples that the NPS developed during this period.

Fortunately, increased funding came along with the expansion of the NPS during this period. Regular appropriations for national parks and monuments increased from $\$ 10,820,620$ in 1933 to $\$ 26,959,977$ in 1939 . New Deal programs underwrote most of the NPS's expansion and

\footnotetext{
${ }^{27}$ Marguerite Shaffer, See America First: Tourism and National Identity, 1880-1940 (Washington, D.C.: Smithsonian Institution Press, 2001) 138-140.

${ }^{28}$ Shaffer, 203.

${ }^{29}$ Ian Firth, "Blue Ridge Parkway: Road to the Modern" in Design with Culture: Claiming America's Landscape Heritage, ed. Charles A. Birnhaum and Mary V. Hughes (Charlottesville: University of Virginia Press, 2005, 179-202.
} 
development during this period. From 1933 to 1937, NPS received $\$ 40,242,691.97$ from the Public Works Administration; $\$ 24,274,090.89$ from the Works Progress Administration; $\$ 82,250,467.66$ from the Civilian Conservation Corps; and \$2,490,678 from the Civil Works Administration. By 1940, emergency relief appropriations made up approximately two-thirds of the total appropriations. ${ }^{30}$

The expansion of the National Park System and dramatic increase in appropriations allowed the NPS to broaden its inclusion of sites and the type of projects it would undertake, most notably the development of its history program. The Antiquities Act of 1906 assigned the responsibility of historical and archaeological sites to the Department of the Interior. It was a part of the NPS mandate when it was created in 1916 to administer seven national monuments of historical and archaeological significance, and Mesa Verde National Park, the first park created for its historical significance. This group grew to sixteen units in 1928. NPS Director Horace Albright, during his tenure from 1929 to 1933 , sought to advance historic preservation in the agency and created George Washington Birthplace National Monument and Colonial National Monument in $1930 .^{31}$

The advancement of history programs in the NPS, an organization known for its scenic preservation, prompted the creation of a historical division in the Branch of Research and Education in 1931. Verne Chatelain first headed the NPS History Program. He had the important task of reorienting the NPS from its former identity of western natural areas to the historical parks of the east and to nurture the nascent history program. In 1932, he submitted a proposal calling for a comprehensive historic sites survey, which would establish standards for these sites

\footnotetext{
${ }^{30}$ Unrau and Williss, Chapter 3.

${ }^{31}$ Harlan Unrau and G. Frank Williss, "To Preserve the Nation's Past: The Growth of Historic Preservation in the National Park Service During the 1930s," The Public Historian, volume 9 number 2, Spring 1987, 19-20.
} 
and identify those of particular significance to the country. Chatelain further emphasized the NPS's role in interpreting these sites for the public. ${ }^{32}$

This new division required a new kind of NPS employee who was trained in the historical profession and could do the necessary documentation and planning needed for preservation, restoration, and interpretation of historic sites. The development of George Washington Birthplace, Colonial, and Morristown National Historical Parks before the 1933 reorganization allowed the division to establish the foundations for a successful program when the number of historic sites nearly quadrupled. ${ }^{33}$ This division played an integral role in the amount of work produced by the New Deal make-work programs. "Historical technicians" as they were called, often worked in the field doing research and planning at historic sites in tandem with projects as they progressed.

Denise Meringolo charts the emergence of the public history profession in the NPS during this decade in her dissertation "Turning Nature into History: The Professionalization of Public Historians in the National Park Service during the 1930s." Collection, preservation, and commemoration were popular cultural trends during the Progressive Era, and people began to compete for claims in expertise and specialty. This competition led to a clash between official and vernacular cultural expressions. The NPS emerged during the 1930s "to mediate competing visions of the American past by reconciling popular and official forms of patriotic language." During this period, federal bureaus and policies, including Chatelain's History Program, were established to set forth the parameters of public history. These parameters were meant to create "a uniform, coherent, popular and broadly meaningful American past," according to

\footnotetext{
${ }^{32}$ Unrau and Williss, 21-22.

${ }^{33}$ Unrau and Williss, 24.
} 
Meringolo. ${ }^{34}$ The NPS had a distinct advantage of mediating these meanings, because they were able to interpret history in situ—at the historic sites—a distinct advantage they held over other institutions, notably the Smithsonian.

The New Deal also developed another kind of preservation professional — the historical architect. FDR activated the Historic American Buildings Survey (HABS) on December 12, 1933. The HABS program hired 1,000 architects, photographers, and draftsmen to survey, measure, photograph, and draw "important antique buildings," in an effort to create a kind of album representing American architectural styles and building techniques from the smallest utilitarian structures to the most iconic and monumental. This reflects the documentary impulse of the era as exemplified by other New Deal projects, such as the Farm Security Administration's photo-documentation of rural life or Federal Writers' Project's collection of slave narratives. HABS documentation would become a prerequisite for any historic preservation project.

The Works Progress Administration funded HABS, but left the administration to NPS. The NPS organized HABS offices by districts, and these offices were guided by architects such as John O'Neill, Thomas T. Waterman, and Thomas C. Vint in the Branch of Plans and Designs. The American Institute of Architects, which had long been interested in such a survey, helped the NPS set up 39 districts across the country and to find the staff for them. The regional organization of the survey was a conscious decision to help document larger regional trends and assist in local preservation planning that was beginning to emerge during this period. The purpose of the survey was to document structures that were at high risk of demolition. This survey helped assign levels of significance before there was a National Register of Historic Places program. The HABS program continued from 1934 to 1941 . The survey covered

\footnotetext{
${ }^{34}$ Meringolo, 276-277.
} 
approximately 7,000 historic structures nationwide; about one-half were photographed and onethird were measured and drawn by the end of $1941 .{ }^{35}$

World War II temporarily suspended HABS work, but it was resumed after the war and continues today, making it one of the few New Deal programs to survive. Complementary Heritage Documentation Programs were later developed, including the Historic American Engineering Record, Historic American Landscape Survey, and Cultural Resources Geographic Information Systems. Altogether, Heritage Documentation Programs have recorded over 40,000 historic sites and structures, providing the baseline information for rehabilitation and restoration. ${ }^{36}$ The HABS program developed during the 1930s set the bar as to how historic structures should be documented by advocating a systematic survey. It also played a substantial role in the professionalization and bureaucratization of historic preservation and making it an interdisciplinary field.

The development of the NPS History Program and HABS is indicative of the emergence of the federal government under the auspices of the NPS as a leader in American historic preservation. Its role in the field was reinforced and formalized with the passage of the Historic Sites Act in 1935. Historians Unrau and Williss call it the "magna carta" for historic preservation. It gave the federal government a general policy for the preservation of nationally significant historic sites, buildings, and objects, and put the National Park Service in a powerful

\footnotetext{
${ }^{35}$ See Lisa Pfueller Davidson and Martin J. Perschler, "The Historic American Buildings Survey: During the New Deal Era: Documenting 'a Complete Resume of the Builders' Art,'” CRM Journal 1 (2003): accessed September 20, 2010, http://crmjournal.cr.nps.gov/04 article sub.cfm?issue=Volume\%201\%20Number\%201\%20Fall\%202003\&page=1\&

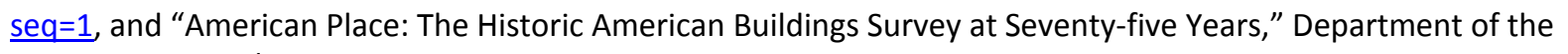
Interior Museum/ Historic American Buildings Survey (Washington, D.C.: Department of the Interior, 2008).

${ }^{36}$ Davidson and Perschler; Department of the Interior/ Historic American Buildings Survey.
} 
position to influence historic preservation policy, historic site development, and interpretation on

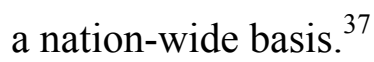

While the emergence of these history programs are perhaps not well known, the Civilian Conservation Corps (CCC) arguably remains the most popular New Deal program in American memory for its accomplishments in natural conservation. However, the CCC's contributions to historic preservation are frequently down played or ignored by CCC scholars. CCC camps frequently provided the manual labor to undertake historic preservation activities. Enrollees are apt to be recalled as "Soil Soldiers" in "Roosevelt's Tree Army" for their natural conservation efforts. Perhaps this is rightly so, because their environmental contributions are easily quantifiable and impressive. For example, they planted over two billion trees; slowed soil erosion on 25 million acres of land; stocked approximately one million fish; and devoted over six million man days to fighting fires. However, they also restored 3,980 historic structures. ${ }^{38}$

This disconnect between the CCC and historic preservation is perhaps due to the terminology used during the period. Neil Maher notes that "the very notion of what constituted Corps conservation was fluid during the New Deal years," which may explain why historic preservation was subsumed under conservation. ${ }^{39}$ The CCC broadened its definition of “conservation," to include not only environmental improvements, but also "historical conservation." These activities were often in tandem with other environmental work or recreational development, which overshadowed the historic preservation work. For example, the

\footnotetext{
${ }^{37}$ Unrau and Williss, 33-35.

${ }^{38}$ One 1942 congressional report notes that 3,961 historic structures were restored, however this report only takes into account work completed up to April 1941. See "Civilian Conservation Corps, monograph by Legislative Reference Service, Library of Congress" in Senate Documents $77^{\text {th }}$ Congress, $2 d$ Session, Miscellaneous (Washington, D.C.: United States Government Printing Office, 1942), 61-67. Other secondary source material indicates that the final number is 3,980. See pamphlet "History of the Civilian Conservation Corps-And its Lasting Legacy," Edinburg, Virginia: Civilian Conservation Corps Legacy Inc., 2010.

${ }^{39}$ Maher, 44.
} 
$\mathrm{CCC}$ was involved in the preservation and restoration of Hopewell Village, including the reinforcement of the blast furnace, within the larger development of the French Creek Recreational Demonstration Area. ${ }^{40}$ The type of historic preservation work being performed was closely associated to other typical, environmental $\mathrm{CCC}$ activities. For example, two $\mathrm{CCC}$ companies were placed at Gettysburg and in addition to cleaning up the battlefield monuments, they engaged in landscaping, forestry work, and cut cordwood for local needy families. ${ }^{41}$ In CCC terms, they were simply landscaping and doing forestry work. In historic preservation terms, however, they were undertaking battlefield restoration.

The CCC was indeed involved in numerous historic preservation projects. In addition to the two companies established at Gettysburg to undertake battlefield restoration, there were also companies at Richmond, Monticello, Williamsburg, Yorktown, Fredericksburg, and Wilderness, Virginia. $^{42}$ In the Maryland and Washington DC area (CCC District Number 3 in the Third Corps), CCC companies performed historic preservation work at C\&O Canal, Fort Frederick, Washington Monument State Park, Fort Dupont, and Fort Washington. ${ }^{43}$ These companies undertook a variety of preservation activities, such as battlefield restoration, historic building and structure repair/reconstruction, monument preservation, and fort reconstruction. However, the NPS required documentation before any preservation could be undertaken. CCC personnel worked in tandem with NPS historians and HABS architects.

\footnotetext{
${ }^{40}$ Robert Fechner, Annual Report of the Director of the Civilian Conservation Corps (Washington, D.C.: United States Government Printing Office, 1938), 45.

41 Joseph M. Speakman, At Work in Penn's Woods: The Civilian Conservation Corps in Pennsylvania (University Park, PA: The Pennsylvania State Press, 2006), 150.

42 "Battlefields Park Measure is Signed," The Sunday Star, March 8, 1936, A-15; West, 117; Edgar Brown, The CCC and Colored Youth (Washington, D.C.: United States Government Printing Office, 1941); Civilian Conservation Corps, Official Annual 1937: District No. 3, Third Corps Area, Civilian Conservation Corps, (Baton Rouge, LA: Direct Advertising Company, 1937), 77, 101.

${ }^{43}$ Civilian Conservation Corps, Official Annual 1937: District No. 3, Third Corps Area, Civilian Conservation Corps, 25, 29; Cornelius W. Heine, National Capital Parks: A History (Washington, D.C.: National Park Service/ National Capital Parks, 1953) accessed September 30, 2010, http://www.nps.gov/history/history/online books/nace/adhi3c.htm.
} 
The convergence of New Deal programs involved in history related activities, such as HABS and the CCC, with FDR legislation, notably Executive Order 6166 and the Historic Sites Act of 1935, indicated a larger cultural trend of how Americans during the Great Depression turned to the past for comfort. The uncertainty of the future caused people to look nostalgically towards America's past for hope, inspiration, and a sense of American exceptionalism. This is perhaps why the HABS program looks at a range of buildings from the humblest of beginnings to statements of power, with special interest to American ingenuity. This Historic Sites Act, according to Unrau and Williss, "represented a popular idea at a time of economic crisis when the nation needed a sense of its cultural heritage," and was evidence of a "new cultural nationalism." ${ }^{44}$

In this chapter, it is apparent that a vortex of historical and cultural forces during the Great Depression had a profound impact on the country's landscape during this period. The FDR administration utilized a progressive conservation ethic to create unique make-work programs to provide relief for those affected by the tough economic climate and invest in the country's natural and cultural resources. It completed projects that reflected other cultural movements that had been in progress for decades. Projects such as state and national park development, Recreational Demonstration Areas, and parkways promoted increasingly urban Americans out into rural areas to recreate in order to improve their own physical well-being and become better American citizens. The growing emphasis on preserving historic sites also reveals the federal government's desire to create a democratic American narrative, in which the public could find inspiration and hope for the future. When examined on their own, these events and movements seem incredibly disparate, such as the Civilian Conservation Corps and the historic preservation

\footnotetext{
${ }^{44}$ Harlan Unrau and G. Frank Williss, "To Preserve the Nation's Past: The Growth of Historic Preservation in the National Park Service During the 1930s," The Public Historian, volume 9 number 2, Spring 1987, 33-34.
} 
movement. However, they overlapped in many ways, and had a tremendous impact on the American landscape. The next chapter utilizes the C\&O Canal as a case study for how these forces created a kind of "perfect storm." In this instance, the storm transformed a defunct transportation system into a recreational park. 


\section{CHAPTER THREE}

\section{C\&O Canal-A Case Study}

"It can be said that history, like beauty, lies in the eye of the beholder, as preservation decisions reflect the values of the preservationist as much as the merits of that which is preserved." ${ }^{45}$ The following case study of the C\&O Canal certainly demonstrates this point. Civilian Conservation Corps and Public Works Administration workers directed by the National Park Service rehabilitated the first twenty-two miles of this historic canal for recreational use as a New Deal public works project. This large-scale implementation of adaptive reuse meant that the historic landscape of the $\mathrm{C} \& \mathrm{O}$ Canal radically changed into a very different reality to meet society's needs and sensibilities. ${ }^{46}$ Park planners and New Deal workers transformed the defunct transportation system into a recreational park, fundamentally altering the canal's historic landscape. Park plans envisioned such a park to fulfill the country's desire for recreation areas that improved the physical and mental well-being of its citizens, thereby making them better Americans. Recognizing the conscious preservation decisions made in the case of the $\mathrm{C} \& \mathrm{O}$ Canal gives a deeper understanding of the federal government's early involvement in historic preservation during the latter part of the Great Depression. It reveals a prevalent challenge for park planners during this period to manage competing visions between historic preservation, natural preservation, and recreational development.

\footnotetext{
${ }^{45}$ Charles Birnhaum and Mary Hughes, Design with Culture: Claiming America's Landscape Heritage (Charlottesville: University of Virginia Press, 2005), 1.

${ }^{46}$ NPS historian Barry Mackintosh in his administrative history on the C\&O Canal says that the adaptive reuse of the C\&O Canal "has never been practiced on a larger scale nor more successfully than in this instance." See Barry Mackintosh, C\&O Canal: The Making of a Park (Washington, D.C.: National Park Service, 1991).
} 
Canals are frequently represented as "quaint," "primitive," and "old-fashioned," which is indicative of the nostalgia that surrounded canals during their operation, in their preservation, and also in their interpretation. The popularity and increasing efficiency of the railroad put an end to the short-lived American canal era. However, canal supporters who were disenchanted by the radical change wrought by railroads after the Civil War, frequently turned to quiet, bucolic, and nostalgic representations of the simplicity of canal life in their search for the "pastoral ideal." These representations are quite at odds with the reality of American canals, since they were often busy, unsanitary, dangerous, and frequented by rowdy boatmen. Nevertheless, these representations carried over into the twentieth century when preservationists wished to preserve these "ancient waterways," while they were experiencing the boom of the automobile, airplane, and urban sprawl. These nostalgic representations also permeate public history interpretation of these sites, especially the $\mathrm{C} \& \mathrm{O}$ Canal. ${ }^{47}$ Further, the emphasis on the natural landscape surrounding the artificial waterway in these representations was appealing for natural and recreational use. The desire for natural and recreational amenities along the waterway ultimately allowed changes in the new adaptive reuse, which would highlight these features, but at the expense of the historic landscape.

Washington, D.C. planners had their eyes on the C\&O Canal for quite a time before the government was able to purchase it. The 1901 McMillan Plan gave a list of recommendations by four of the nation's top design professionals—Daniel Burnham, Charles McKim, Frederick Law Olmstead, Jr., and Augustus Saint-Gaudens - for the improvement of parks in the District of Columbia. The Plan generally recommended the return to L'Enfant's original plan, but with

\footnotetext{
${ }^{47}$ For a more in depth discussion regarding representations of the $C \& O$ Canal, see unpublished essay by the author, "The 1886 Flood: Representations of the Canal's Golden Age," Unpublished--West Virginia University, May 2009.
} 
certain modifications. It proposed a "Potomac Drive," which would connect Washingtonians to the Great Falls area, and follow along the bluffs to provide clear vistas of the Potomac River. ${ }^{48}$ Additionally, the Plan advocated the preservation of the C\&O Canal, still in operation by the C\&O Canal Towage Company, as a scenic and recreational amenity that was both "primitive" and "quaint." The Plan stated: "no change should come to pass in the character of the canal that will tend to transform its primitive character and quaint beauty. The canal has a charm of its own, as, half disclosed and half revealed, is the slow, old-fashioned movement of the boats and of the people on and near this ancient waterway." The canal would provide "elements of gayety and life to be enjoyed by the passers-by.",49

The Potomac Drive idea was not immediately put in place, but others, too, recognized the potential in the C\&O Canal. Horace Albright hiked the towpath on his days off as staff member to Secretary of the Interior Franklin K. Lane in 1913, and later with Stephen Mather in 1915 when Mather was Assistant to the Secretary. He and Mather discussed hiking the entire towpath from Cumberland to Georgetown, and even examined the canal intake structures in Cumberland when their train to Chicago was delayed. Mather became the first Director of the National Park Service in 1916; Albright followed, serving as Director from 1929 to 1933. Albright's day trips to historic sites around the Washington, D.C. area later proved to be influential as he built the

\footnotetext{
${ }^{48}$ The Great Falls of the Potomac poses the greatest change in elevation along the Potomac River. While it posed a tremendous obstacle to water transportation, Washingtonians frequently visited the falls throughout the nineteenth century as a respite from the hot, humid Washington summers.

${ }^{49}$ U.S. Congress, Senate, Committee on the District of Columbia, The Improvement of the Park System of the District of Columbia (Washington, D.C.: Government Printing Office, 1902) 96, accessed September 30, 2010, http://www.nps.gov/history/history/online_books/mcmillan/plan.pdf.
} 
foundations of the NPS history program and brought the agency in the historic preservation "business."

Despite the influential clout held by Albright and Mather, their hikes on the canal were much in the same spirit as other individuals and social clubs that recreated on or near the canal for many years. For example, John Cowan and his wife wrote a narrative and compiled a photographic record about their 1916 journey down the C\&O Canal in their recreation craft, affectionately called Sometub. ${ }^{51}$ In 1908, The Washington Biologists' Field Club adopted a site on Plummer's Island, which is adjacent to the canal, and has been there ever since. ${ }^{52}$ The Washington Canoe Club built their clubhouse on canal land in 1904, and is significant for its role in developing flatwater canoe racing as an Olympic sport. Today, it still trains Olympic canoe and kayak athletes. ${ }^{53}$

Between 1926 and 1930, the parkway idea was revived with the momentum of the "Good Roads movement" and the abandonment of the canal after the 1924 flood. In 1926, Lt. Col. J. Franklin Bell, engineer commissioner for the District, proposed using the canal as a federal highway to Cumberland. Bell was particularly interested in the commercial prospects of such a roadway, but his plan also provided for some measure of preservation for the canal. His bill languished in Congress. However, Representative Louis Cramton of Michigan introduced another bill in December 1928. This bill called for the development of the George Washington Memorial Parkway, which was to include:

\footnotetext{
${ }^{50}$ Horace Albright, Origins of National Park Service Administration of Historic Sites (Philadelphia: Eastern National Park \& Monument Association, 1971), 3-4, 15.

${ }^{51}$ John Pryor Cowan, Sometub's Cruise on the C\&O Canal: The Narrative of a Motorboat Vacation in the Heart of Maryland (Pittsburgh: Pittsburgh Print Co., 1916).

52 "The History of the Washington Biologists' Field Club on Plummers Island," Washington Biologists' Field Club, accessed October 12, 2010, http://www.pwrc.usgs.gov/resshow/perry/bios/History.htm.

53 "The History of the Club," Washington Canoe Club, accessed October 12, 2010, http://www.washingtoncanoeclub.org/History/.
} 
"the shores of the Potomac, and adjacent lands, from Mount Vernon to a point above the Great Falls on the Virginia side, except within the City of Alexandria, and from Fort Washington to a similar point above the Great Falls on the Maryland side except within the District of Columbia, and including the protection and preservation of the natural scenery of the Gorge and the Great Falls of the Potomac, the preservation of the historic Patowmack Canal, and the acquisition of that portion of the Chesapeake and Ohio Canal below Point of Rocks." 54

President Hoover signed the Capper-Cramton Act on May 29, 1930. According to Mackintosh, the National Capital Park and Planning Commission planned to restore the canal prism for recreation purposes, and build a road paralleling the canal on either the towpath or berm sides. $^{55}$ The Capper-Cramton Act originally came with nine million dollars, but federal spending was limited during the lean years of the Hoover administration. Plans for the $\mathrm{C} \& \mathrm{O}$ Canal were again put on hold. Although neither prescriptions offered for the C\&O Canal by the Bell Bill or Capper-Cramton Act ever reached actuality, both demonstrate the uncertainty of the future the canal - a sort of conflict between the era's progressive sensibilities with the nostalgic desire to preserve the canal.

"The Potomac River here is due for a rapid rise but there is no danger of flood unless the predicted rainfall during the next 24 hours is especially heavy," The Evening Star, a Washington, D.C. newspaper, reported on St. Patrick's Day $1936 .^{56}$ Later that night, however, the rain did increase and resulted in one of the worst floods on record, devastating the entire Potomac River Valley. When the waters receded the damage was ascertained; property loss for the northeast was estimated to be $\$ 225$ million and 153 people died. ${ }^{57}$ President Franklin Delano Roosevelt delayed his vacation to personally command the Federal mobilization to aid flood victims, and

\footnotetext{
${ }^{54}$ H.R. 26, $71^{\text {st }}$ Congress; Congressional Record 71: 482.

55 Mackintosh, 6-8.

56 “Upper Potomac Flood Forecast: D.C. Inundation Unlikely Unless Coming Rain is Very Heavy," The Evening Star, March 17, 1936, A-1.

57 "Rivers Go Higher with 153 Dead in U.S.," The Evening Star, March 20, 1936, A-1.
} 
flood relief money flowed from his administration by the millions. ${ }^{58}$ The Evening Star editor Theodore Noyes remarked in his column that the flooding in the northeast was nature's punishment against man's reckless abuse of nature, and took the opportunity to support the reforestation, soil control, and flood prevention being undertaken by FDR's New Deal programs. ${ }^{59}$

A reporter flying over the flooded areas around the Nation's capital observed the C\&O Canal: "Sometimes the canal emerged as a separate ribbon of dirty yellow with the cinder-topped towpath separating it from the river. Sometimes the two merge together in one calm, resistless torrent of yellow." ${ }^{60}$ Little attention was paid to the 108 year old waterway during the drama of the 1936 flood, since the canal was abandoned after the 1924 flood. ${ }^{61}$ The specific damage the 1936 flood caused to the canal is unknown, because of the past flood damage of 1924 and twelve years of subsequent neglect on the century old waterway. However, families who still lived along the canal were forced from their wrecked and ruined homes. Local officials hurried to these areas to prevent typhoid outbreaks and looting. Montgomery County Commissioner Robert D. Hagner took the flood as an opportunity to sponsor an order to remove "'Dens of Vice"” on land belonging to the $\mathrm{C} \& \mathrm{O}$ Canal Company. These were homes built by squatters on tax-exempt canal land, and had apparently denigrated into unsavory places. Applicants who wished to

\footnotetext{
58 "Relief is Rushed by White House," The Evening Star, March 20, 1936, A-1.

${ }^{59}$ Theodore Noyes, "The Flood's Challenge," The Evening Star, March 20, 1936, A-10.

${ }^{60}$ Swollen River Like Big Serpent Clutching Valley's Landmarks," The Evening Star, March 19, 1936, A-4.

${ }^{61}$ Most flood reports during the nineteenth century and up until 1924 enumerated the damage of the canal and reported when it could begin operations again. This was not the case in 1936, showing that the community did not believe it to be a viable transportation system. The damage caused by the 1924 flood was not repaired by the C\&O Canal Towage Company and boats ceased to run on the canal. For a further discussion of how floods affecting the C\&O Canal were discussed by the media, see unpublished essay by the author, "The 1886 Flood: Representations of the Canal's Golden Age," Unpublished-West Virginia University, May 2009.
} 
rebuild their homes or repair old ones had to appeal to the commissioners. ${ }^{62}$ The transformation of the C\&O Canal had begun.

Cathy Stanton argues in her book, The Lowell Experiment: Public History in a Postindustrial City, that the mill town of Lowell, Massachusetts went through a cycle of "innovation, decline, and rebirth." Lowell went through a depressed period of deindustrialization when the manufacturing companies left before the city could be "re-branded" by the NPS through heritage tourism as an economic stimulus. Before this "re-branding" process could occur, the "image of decline" had to be reversed. ${ }^{63}$ Cultural geographer John Brinckerhoff Jackson wrote that in contemporary preservation efforts: "There has to be (in our new concept of history) an interim of death or rejection before there can be renewal or reform. The old order has to die before there can be a born-again landscape."64 The floods of 1924 and 1936 represent this necessary "decline" period in order for the canal to be "re-made." Although the floods "naturally" began the process of removing some of the "images of decline" on the canal, by destroying homes and buildings, local officials stepped in to carry on where the floods left off, by removing so-called "Dens of Vice."

The federal government took the 1936 flood as an opportunity to purchase the abandoned canal, thereby formalizing the "re-branding" process. In the process of its own transformation under the Roosevelt administration, the federal government was spending unprecedented amounts of money through New Deal programs. FDR signed the National Industrial Recovery Act on June 16, 1933, which created the Public Works Administration (PWA) and enabled the

\footnotetext{
62 "Guards on Duty in Montgomery," The Evening Star, March 22, 1936, A-3.

${ }^{63}$ Cathy Stanton, The Lowell Experiment: Public History in a Postindustrial City (Amherst: University of Massachusetts Press, 2006), 5, 109.

64 John Brinckerhoff Jackson, The Necessity for Ruins and Other Topics (Amherst: University of Massachusetts Press, 1980), 102.
} 
President to acquire any real or personal property by purchase or condemnation for make-work programs. Conditions were ripe for the government to acquire the canal.

FDR's uncle, Frederic Delano, a former railroad man and chairman of the National Capital Parks \& Planning Commission, brokered a deal with the B\&O Railroad for the purchase of the $\mathrm{C} \& \mathrm{O}$ Canal. The $\mathrm{B} \& \mathrm{O}$ was undergoing its own financial difficulties, owed a significant sum to the Reconstruction Finance Corporation, and saw the appeal in giving the neglected canal to a non-competitor. The $\mathrm{B} \& \mathrm{O}$ provided its interest in the canal to RFC as collateral, although, it did not hold actual title to the land. Maryland and Washington, D.C. courts then had to appoint B\&O officials as receivers, since all the C\&O Canal Company's receivers had died. Negotiations were complicated by the railroad's desire to keep portions of the canal above Point of Rocks, which it wished to retain for railroad use, but NPS Director Arno Cammerer insisted that continuity of the canal bed was essential to the deal. As the B\&O's financial conditions continued to deteriorate, a deal was finally made September 28, 1938, and the federal government bought the property for a sum of $\$ 2.5$ million. ${ }^{65}$ Two million dollars went towards the canal's acquisition, while $\$ 500,000$ was allocated to "restoration" purposes. ${ }^{66}$

\footnotetext{
${ }^{65}$ Mackintosh, 8-20.

${ }^{66}$ Federal documents from the period identify the conservation activities at the C\&O Canal as "preservation" or "restoration." The Secretary of the Interior's Standards Preservation and Guidelines for Preserving Historic Buildings articulates preservation as "the act or process of applying measures necessary to sustain the existing form, integrity, and materials of an historic property." It articulates restoration as "the act or process of accurately depicting the form, features, and character of a property as it appeared at a particular period of time by means of the removal of features from other periods in its history and reconstruction of missing features from the restoration period." The activities completed on the C\&O Canal during this period perhaps are better described as rehabilition, defined as "the act or process of making possible a compatible use for a property through repair, alterations, and additions while preserving those portions or features which convey its historical, cultural, or architectural values." See The Secretary of the Interior's Standards for the Treatment of Historic Properties with Guidelines for Preserving, Rehabilitating, Restoring, and Reconstructing Historic Buildings (Washington, D.C.: National Park Service, 1992).
} 
While the 1936 flood provided the opportunity for the government to acquire the canal property for recreational purposes, the real motivation between 1936 and 1938 was the immediate need for make-work programs to relieve unemployment. In June 1938, the NPS was anxious to acquire the property, because it had several Civilian Conservation Corps companies available to do work on the C\&O Canal. Acting NPS Director A.E. Demaray wrote to Daniel Willard of the $\mathrm{B} \& \mathrm{O}$ Railroad asking the receivers for permission to allow the CCC companies to begin work before the final purchase was made. Demaray wrote: "As partial justification for the proposed purchase of the Chesapeake and Ohio Canal property, it has been stated that the property is ideally adaptable to use for Civilian Conservation Corps purposes. We have in mind such CCC activities as erosion control, landscape and trail development, lock restoration, cleanup operations, etc." Demaray feared that if they let the opportunity pass, the NPS might not be able to utilize CCC services in the future. "Therefore," he wrote, the NPS was "anxious to commence $\mathrm{CCC}$ work on the canal at the earliest possible moment. ${ }^{, 67} \mathrm{He}$ further noted that if the receivers would not grant permission, the NPS would seek a court order. ${ }^{68}$

Two CCC camps were allocated to the canal in June and October 1938. Camp NP-MD-1 was situated near Cabin John, Maryland, and was occupied by CCC Company 325 from midJune, 1938 to April 1, 1942, or from the $11^{\text {th }}$ to $18^{\text {th }}$ enrollment periods. ${ }^{69}$ Camp NP-MD-2 was located just a short distance away at Carderock. It was occupied by CCC Company 333 from October 5, 1938 to November 15,1941 , or from the $12^{\text {th }}$ to $18^{\text {th }}$ enrollment periods (See Figures 1-4). Both camps supported approximately 200 men, and the two camps often worked together as

\footnotetext{
${ }^{67}$ Letter, A.E. Demaray to Daniel Willard Jr., June 4, 1938, Central Classified Files, RG 79, E-10, Box 2836, Folder A, NARA.

${ }^{68}$ In March, the NPS questioned whether or not they could use PWA funds for CCC work on property they did not own and was not yet a National Park. Memorandum for Secretary of the Interior, A.E. Demaray, March 11, 1938, Central Classified Files, RG 79, E-10, Box 2836, Folder A, NARA.

${ }^{69} \mathrm{~A}$ CCC enrollee could enroll in six month terms called enrollment periods.
} 
one. Their work primarily focused on rehabilitating the first 22 miles of the canal towpath and prism into a recreational trail and waterway, and then later turned to rehabilitating some of the historic buildings to retain them as scene-setters in the landscape.

The decision to concentrate on the first 22 miles and to locate the CCC camps in a central location in that section came from the desire to develop recreational amenities close to Washington, D.C. to encourage city dwellers to canoe the canal waterway or hike the towpath. This section also had a higher concentration of historic structures. Albeit strategic, this decision meant that the 162 mile stretch of canal from Seneca to Cumberland remained abandoned until a decision regarding a parkway could be reached. Although the eastern section had a higher concentration of historic structures, this western stretch of the canal was no less significant than the eastern section and naturally had a greater number of historic structures. The decision to not do anything to this long stretch of the canal allowed ample time for the canal to return to nature and the canal infrastructure to fall further into disarray. This not only made restoring cultural resources a formidable challenge in the future, but placed an increasing emphasis on natural preservation at the expense of the historic landscape. However, some historic buildings ironically benefited from this abandonment as their features were preserved through benign neglect. For C\&O Canal visitors today, the western section is a value judgment. Some see beauty in the canal as a "magnificent wreck," in which the infrastructure is gradually decaying with nature taking over. $^{70}$

The scramble to get the CCC camps in place and the canal's land acquisition finalized left little time for any real planning. NPS officials did not have a clear vision about the final use

\footnotetext{
${ }^{70}$ Historian Walter Sanderlin calls the canal a "magnificent wreck" in his seminal history of the C\&O Canal. See Walter Sanderlin, The Great National Project: A History of the C\&O Canal (Baltimore: John Hopkins Press, 1946).
} 
for the canal, whether it would become a parkway or preserved for other purposes. Early press releases stated that the NPS would undertake "two distinct phases of conservation, one recreational, the other historic." The first 22 miles would be restored for recreational use, such as canoeing, boating, and fishing. Beyond Seneca, the NPS might create a parkway. ${ }^{71}$

As these statements reached the public about the possibility of a parkway, NPS Director Arno Cammerer tried to alleviate concerns for those advocating the canal's preservation. Cammerer sent this reply in June 1938: "Any announcement of our plans certainly was unauthorized because we have no final plans as yet. There is a good deal of talk floating around about this and that but the only thing that I have heard that relates to roads is that possibly the section between Monocacy and Harpers Ferry might be utilized in part for a bordering road. There is nothing definite, however, and these are just rumors that are floating around." $\mathrm{He}$ continued, "I am keeping an open mind on the subject because while I would certainly like it as a waterway for its entire distance, nevertheless there may be portions of it to which study might be given for other purposes, if only to establish that those purposes are not desirable." ${ }^{72}$

The uncertainty about the final vision of the park allowed three different competing visions to shape the NPS's efforts between 1938 and 1942. First, there was desire to formalize the canal as a place of public recreation. A Study of the Park and Recreation Problem of the United States produced by the NPS in 1941 identified canals as rife with recreational potential, citing the C\&O Canal specifically and its proximity to a very large population. ${ }^{73}$ The NPS appropriated the canal towpath for hikers and the canal prism for canoeists, which fundamentally

\footnotetext{
${ }^{71}$ Memorandum, "Old Chesapeake and Ohio Canal Rich in Historic Associations," Department of the Interior to the Press, April 10, 1938, Central Classified Files, RG 79, E-10, Box 2836, Folder A, NARA.

72 Letter, Arno Cammerer to Myron Avery, June 9, 1938, Central Classified Files, RG 79, E-10, Box 2836, Folder A, NARA.

${ }^{73}$ National Park Service, A Study of the Park and Recreation Problem of the United State (Washington, D.C.: United States Government Printing Office, 1941), 127.
} 
changed the nature of the canal as a place of commerce and private enterprise to a place of public recreation. The willingness to adaptively reuse the towpath and canal prism reflects the second desire — to preserve the canal's historic resources. Secretary of the Interior Harold Ickes said that the canal was particularly significant because it contained "some of the most picturesque and historic features in the East." 74 The NPS's idea of historical restoration for the canal "would consist of the repair and rebuilding of certain of the century-old lock houses and their appurtenances, the famous Great Falls Tavern, and similar structures, and the reconditioning of selected sections of the tow-path which provides an ideal route for hikers." This approach treated the canal's historic buildings like accessories along the trail and waterway. The third vision involved the "picturesque" qualities of the canal. After years of disuse, many parts of the canal became overgrown with vegetation, giving a romantic or wild feel to the canal. Scenic preservation was the NPS's mandate since its inception, so preserving the natural beauty also played a role in the transformation of the canal into a recreational entity.

As the CCC crews set up their camps, NPS historians and Historic American Building Survey (HABS) architects furiously set to work researching and documenting the historic $\mathrm{C} \& \mathrm{O}$ Canal. NPS historians began work on the C\&O Canal as the NPS History Program was maturating and professionalizing the field of public history. Cammerer approved a policy on June 20, 1938, which set forth a research and development policy for historic sites in the NPS. This policy was built on the fundamental principle that research should precede development. Planning could only be undertaken when all the research data could be considered and research should only be conducted by trained personnel. The NPS should be able to authenticate and

\footnotetext{
${ }^{74}$ Memorandum, "Old Chesapeake and Ohio Canal Rich in Historic Associations," Department of the Interior to the Press, April 10, 1938, Central Classified Files, RG 79, E-10, Box 2836, Folder A, NARA.
} 
justify its preservation decisions at any point in time, based on solid research. ${ }^{75}$ Although the NPS historians did not finish their research on the $\mathrm{C} \& \mathrm{O}$ Canal before project work began, their findings did direct the work as it progressed making it one of the first NPS projects where historical research was closely tied to park development.

The NPS first began to document the canal and its structures through HABS, a New Deal program established in 1933 to hire unemployed architects and photographers to document the country's historic buildings. These surveys at the C\&O Canal reveal how the first generation of HABS architects and photographers operated, which set a precedent for modern survey work and the standard for documentation of historic structures. Many of these architects and photographers were unemployed and needed temporary employment. Field teams were based out of regional offices and travelled to surrounding areas to document structures. They created measured drawings, which generally included floor plans, elevations, architectural details, and construction elements. HABS photographers took large format black-and-white photographs of the buildings to show the surrounding environment and architectural details. HABS surveys today are still based out of regional offices, are supported by seasonal employment, and focus on drawings and photographs. However, surveys now include a detailed history of the building, including historical significance, description, and the structure's evolution. Field teams also utilize hi-tech tools, such as laser scanning.

John Bostrup was a young photographer looking for work when he answered an ad in The Evening Star. Thomas Waterman hired him to go out in the suburbs of Washington, D.C. to

\footnotetext{
${ }^{75}$ Harlan D. Unrau and G. Frank Williss, "To Preserve the Nation's Past: The Growth of Historic Preservation in the National Park Service during the 1930s" The Public Historian 9 (1987), 43.
} 
photograph historic structures. ${ }^{76}$ Bostrup covered Prince George's and Montgomery counties beginning in March 1936 until the end of 1937, using his own camera and film issued by the Department of Interior to produce $5 \times 7$ inch photographs. He often travelled alone, but was occasionally accompanied by a HABS architect, who collected historical data, took measurements, and made drawings. ${ }^{77}$ Even though Bostrup finished his work before the canal was acquired, he spent two days photographing C\&O Canal structures. On August 6, 1936, he photographed Great Falls Tavern, Lock 20, and nearby lockhouse ruins. He photographed Lockhouse 24 and Seneca Aqueduct a month later on September 16, $1936 .^{78}$

A week later, a HABS team descended upon the Monocacy Aqueduct to photograph, measure, and draw one of the most impressive structures on the C\&O Canal. Maryland photographer Edgar H. Pickering photographed the aqueduct, showing vegetation growing out of the masonry on the sides and in the bed. Pickering had been a reasonably successful photographer in Annapolis, but lost his studio and its contents to the bank after the stock market crash. ${ }^{79}$ HABS architects measured the aqueduct on September 22, 1936, and the drawings were completed December 10, 11, and 14. Architect L. Ewald, Jr. checked the measurements and delineated the structure. The drawings erased the vegetation show in Pickerings' photographs, to show in clean simplicity the seven-arched aqueduct.

\footnotetext{
${ }^{76}$ Thomas Waterman was an NPS architect and served as assistant director for HABS. He had experience working for the Society for the Preservation of New England antiquities, where he helped record endangered buildings. Before working for NPS, he worked on the restoration of Colonial Williamsburg. As HABS assistant director, Waterman helped prepare standard techniques for HABS recording. Catherine Lavoie, "American Place: The Historic American Buildings Survey at Seventy-Five Years," Historic American Buildings Survey Exhibit Catalog, 2008, 15.

${ }^{77}$ Catherine Lavoie, “Interview with John O. Bostrup, HABS Photographer, 1936-1937," CRM Journal 7 (2010): 1626.

78 John O. Bostrup, HABS Collection, Library of Congress Prints and Photographs Division, Washington, D.C.

79 "A Short Biography of Edgar H. Pickering," Maryland State Archives, last modified July 22, 1997, accessed October 18, 2010. http://www.msa.md.gov/msa/speccol/photos/html/pickring.html.
} 
After the government purchased the canal in 1938, a more systematic architectural survey of the C\&O Canal was undertaken, which reveals how the HABS survey initially operated and reflects how survey teams operate today. A HABS field team based out of the Washington, D.C. office and working with the National Capital Parks Branch of Plans and Designs conducted two more surveys along the C\&O Canal in 1939. The field team consisted of architects McGrew, McClure, Pick, Berliner, and Gutterson. Two often teamed up on a building — one responsible for measuring, another responsible for delineating. Other times they worked alone. Today, HABS survey teams are based out of regional offices, and still produce measured drawings, photography, and written histories.

HABS Survey MD-56 concentrated on buildings built by the C\&O Canal Company from Lockhouse 5 to Lockhouse 24 in Seneca. The field team produced 44 18x24 inch measured drawings of Lockhouses 5, 6, 7, 8, 9, 10, 11, 12, 13, 14, 16, 21, 22, and 24, as well as Great Falls Tavern, two frame houses, and a log house in the Great Falls vicinity. These drawings show the exterior elevations and floor plans. The architects noted building materials and additions. For some buildings, the HABS architects show great detail in doors, windows, mantles, and hardware. They also sometimes show building damage where repairs were needed. ${ }^{80}$

The focus of the survey on canal lockhouses demonstrated the HABS's interest in identifying building typologies in order to place structures within the framework of larger patterns of architectural development. ${ }^{81}$ All of the canal's lockhouses are nearly identical in plan, dimensions, and materials. ${ }^{82}$ They are typically one and a half stories of brick or stone, and can

\footnotetext{
${ }^{80}$ Drawings, HABS Survey MD-56, 1939, HABS, Prints and Photographs Division, Library of Congress, Washington, D.C.

${ }^{81}$ Catherine Lavoie, “American Place: The Historic American Buildings Survey at Seventy-Five Years," 23.

${ }^{82}$ Further west on the C\&O Canal, some lockhouses have a full second story and are of wood frame or log construction.
} 
be delineated into two different types: Type I and Type II. Type I Lockhouses have a central chimney, and Type II Lockhouses have two end chimneys. The HABS survey played upon these typologies, but was meticulous in noting the differences in all the buildings surveyed, especially their present conditions.

HABS Survey MD-57 is decidedly more eclectic. It focused on other canal structures that did not serve domestic purposes, but contributed to the engineering significance of the canal. This survey predates the establishment of the Historic American Engineering Record (HAER), another Heritage Documentation Service, which focuses on achievements in engineering. The field team recorded the swing bridge at Edwards Ferry at Lock 25 and Seneca Aqueduct. They measured and recorded Lock 20 as a "typical lock," since the locks varied little. However, they also recorded Lock 12, because it had a drop gate instead of the typical swing gate. At Great Falls, they measured the repair shop - the only actual building included in this survey. Someone on the team also measured and delineated a $\mathrm{C} \& \mathrm{O}$ Canal mile marker stone. Interestingly, the field team travelled to Williamsport to record the stop lock, and to Hancock to record an old canal boat. This is the only known time that the team travelled to the western part of the park to record structures. It was done most likely to prepare for the restoration efforts at the stop lock near Lock 16 and the canal barge to be used for tours. ${ }^{83}$

While the HABS teams were in the field, research technicians were busy at work in the archives. The federal government acquired all the records for the C\&O Canal Company and the Patowmack Company upon purchasing the canal in 1938. The concept of a "research technician" was new for the NPS and it was a part of the professionalization of its program to have highly

\footnotetext{
${ }^{83}$ Drawings, HABS Survey MD-57, 1939, HABS, Prints and Photographs Division, Library of Congress, Washington, D.C.
} 
trained personnel doing research in the field. For the $\mathrm{C} \& \mathrm{O}$ Canal project, the Acting Supervisor of Historic Sites recommended two young historians to the positions of "Associate Research Technician.” These technicians were initially NPS employees, but for a time were funded by the PWA and assigned to the CCC to help direct projects. T. Sutton Jett had served from 1933 to 1936 as Historical Assistant and Junior Historian at Fredericksburg, Virginia, conducting research; supervising and planning CCC projects; and planning and directing the interpretive program. Jett took a year off for graduate work at Johns Hopkins University, and afterwards worked as Ranger/Historian at Fort McHenry from June to December 1937. In May and June of 1938, he was temporarily employed as an Associate Historian in Region One, when he was recommended for the job at the $\mathrm{C} \& \mathrm{O}$ Canal. The duties for this position consisted of historical planning, historical research, administration, and public relations. He was required to conduct a field study of the remains of the canal and locate significant historical sites therein to possibly develop for public interpretation. He was also required to study historical sources to provide necessary data for accurate interpretation and restoration. He was also to prepare "detailed research reports on important historical problems." Jett supervised another Research Technician and the "physical development of a historical nature." Jett was also required to work with local officials and citizens in the preparation of an interpretive program. ${ }^{84}$

Rogers W. Young filled the second Assistant Research Technician position. He was responsible for historical research, development plans, administration, and publication. He was required to travel to different depositories, such as the Maryland State Archives and courthouses, and to contact individuals to research the $\mathrm{C} \& \mathrm{O}$ Canal. He had to prepare the historical data for inclusion in development plans, and assist Jett in maintaining correspondence and supervision of

\footnotetext{
${ }^{84}$ Memorandum, Acting Supervisor of Historic Sites to Tolson, August 17, 1938, Central Classified Files, RG 79, E10, Box 2836, Folder B, NARA.
} 
physical developments of a historical nature. He also assisted in reviewing, editing, and preparing historical reports for the canal. ${ }^{85}$

Jett and Young completed a 37-page "preliminary historical memorandum" on the dimensions and construction of the first 22 miles of the canal, a 19-page memorandum on the lockhouses in this section, a 14-page article on the general development of the canal, and a 225 page monograph on canal commerce in Georgetown to $1860 .{ }^{86}$ In June 1939, Jett and Young published "A Preliminary Historical Study on the Area along the Maryland Shore of the Potomac at Great Falls during the Heyday of the Chesapeake and Ohio Canal, 1858-1880.” The main objective of this report was to identify a period of significance, and then include a narrative of the historic structures in the area. Jett and Young identified 1858 to 1889 as the period of significance for the canal, because it was the era of the canal's greatest prosperity. This varies greatly from the 1828 to 1924 period the park uses today as the canal's period of significance. In subsequent pages they justified their decision, citing C\&O Canal Company records and county court records. The report described the various structures in the Great Falls area—both extant and non-extant - and their history Their research supplemented the HABS surveys in that it provided a narrative of the historical changes in the Great Falls area, and included both extant and non-extant buildings. ${ }^{87}$ The research and documentation of Jett, Young, and the HABS teams went to the National Capital Parks Branch of Plans and Design under the direction of Thomas C. Vint. Vint and his staff used this information to direct the rehabilitation of the canal and its structures and the general development of the park.

\footnotetext{
${ }^{85}$ Memorandum, Acting Supervisor of Historic Sites to Tolson, August 17, 1938.

${ }^{86}$ Mackintosh, 37.

87 T. Sutton Jett and Rogers W. Young, "A Preliminary Historical Study on the Area along the Maryland Shore of the Potomac at Great Falls During the Heyday of the Chesapeake and Ohio Canal, 1858-1880," (Hagerstown, Maryland: Chesapeake and Ohio Canal National Historical Park, 1939).
} 
Landscape historian and preservationist Ethan Carr argues that Vint was a significant figure in the development of historic preservation theory and practice as the NPS moved increasingly to the forefront. ${ }^{88}$ Trained in landscape architecture at University of CaliforniaBerkley, Vint started his career with the NPS at Yosemite National Park working under Daniel Hull who invented the Park Service rustic-style. Vint replaced Hull as the NPS's chief landscape architect in 1927, and began expanding the landscape division. Vint and his staff worked to overcome what Vint called the "landscape problem." Carr describes what Vint saw as the "landscape problem:"

The "landscape problem" Vint described was essentially that of landscape preservation, specifically preservation as achieved through public park development. Preserving places by making them into scenic reservations entailed a conceptual and physical transformation. As roads, trails, and other facilities were developed, growing numbers of (mostly automotive) tourists were able to appreciate scenery and other resources, camp, hike, and, in general, "enjoy" the parks. In the process land became landscape; the place became a park. As Vint passionately argued, this transformation needed to be controlled by a unified aesthetic conception (the master plan), which limited the development of roads and other facilities, enhanced a consistent sense of place, and protected scenery from encroachments." 89

By 1931, Vint and his staff developed the "Master Plan," which ran on the assumption that landscape preservation was not passive, but required a limited amount of physical intervention to be successful. Vint knew that if people did not visit parks, because of lack of accessibility, modernization, or appeal, the landscape would not be preserved. He also knew that if people were left without restraint in parks that, too, would damage the landscape. He tried to strike a balance between the two, by controlling the visitor experience through trails and

\footnotetext{
${ }^{88}$ Birnhaum and Hughes, 157.

${ }^{89}$ Birnhaum and Hughes, 162.
} 
facilities. Carr believes Vint's master plans for parks "reflected an ideal of a sustainable society in which people got along with one another and their environment." 90

The majority of Vint's work in the West was on scenic parks. Vint faced a new and unique challenge to the "landscape problem" when he moved his office to Washington, D.C. in the 1930s, at the same time the NPS History Program was developing. He had to find a way to balance scenic and historic preservation. Vint explained: "National Parks fall into two groups, natural and historical. In one, the primary purpose is to preserve and protect one of the great works of nature...In the other, to preserve and protect the scene at one of the great moments of our national history — to stop the clock and hold the scene of the moment in history that makes the area important." $" 91$

"Stopping the clock" at any historical site holds a powerful appeal, but it poses significant problems. Under this philosophy, preservationists, planners, and architects try to give singularity to a landscape that changed and developed over time. "Stopping the clock" ignores other ancillary significant periods, and neglects the layering of the cultural landscape. Nor is it feasible. This certainly posed a problem at the $\mathrm{C} \& \mathrm{O}$ Canal. The area has periods of significance that predate European settlement and extend until 1924. The Jett-Young report, which outlines the period of significance for the park's Master Plan, argues that the canal should be restored to the period of 1858 to 1889 . In the case of the C\&O Canal, it was not just the matter of "stopping the clock," but "rewinding the clock." This allowed the NPS to raze buildings or additions that

\footnotetext{
${ }^{90}$ Birnhaum and Hughes, 163.

${ }^{91}$ Quoted in Birhaum and Hughes, 166.
} 
post-dated 1889, and would most likely be considered historic today, such as the front porch and kitchen at Great Falls Tavern. ${ }^{92}$

NPS architect Albert H. Good also grappled with the implications of the federal government's involvement in historic preservation. Good was mostly concerned with designing park structures in natural areas, and advocated a simplistic, rustic design aesthetic. The idea of a "Frontier Village" greatly sparked his interest, believing it could "bring about a reevaluation of the pioneering virtues and American ideals that seem progressively remote from us in modern life." In terms of historic preservation, Good warned against "the almost irresistible urge to gild the lily," meaning preservationists should not impose their artistic creativity or modern sensibilities when doing restoration work. He believed that restoration work should only be done based on the historical record. If insufficient evidence exists, preservation decisions should be made based on other examples in the region or period. ${ }^{93}$

Rehabilitation work at C\&O Canal first focused on the waterway itself, and the readmission of water from Seneca to Little Falls. ${ }^{94}$ CCC enrollees put in substantial effort to clear debris, silt, and vegetation from the canal prism. They dug a thirty foot channel of six foot depth to keep dredging at a minimum and located it on a two to one slope on the towpath side.

The NPS created these specifications based on the idea that the channel "should be easily located by anyone not acquainted with the waterway." 95 CCC enrollees also repaired significant sections of the towpath and feeder dams. Restoring the prism and towpath required heavy equipment and plenty of labor. CCC photographs show enrollees with shovels and wheelbarrows working to

\footnotetext{
${ }^{92}$ Fortunately, the NPS rethought this policy after the Second World War.

${ }_{93}$ Albert Good, Park and Recreation Structures: Part II-Recreational and Cultural Facilities (Washington, D.C.: United States Government Printing Office, 1938), 186-187.

${ }^{94}$ Memorandum, T. Sutton Jett to Supervisor of Historic Sites, September 25, 1939, Central Classified Files, RG-79, E-10, Box 2836, Folder C, NARA.

${ }^{95}$ Letter, Murray to Gertside, July 20, 1939, Central Classified Files, RG-79, E-10, Box 2836, Folder C, NARA.
} 
restore the towpath (See Figures 7-9). ${ }^{96}$ The CCC also spent a significant amount of time restoring the Widewater section, an ancient river channel that the C\&O Canal Company used for the canal, but was especially susceptible to flooding (See Figures 10-16). They installed a flood control device to lessen the impact of future flood events.

Lock repair and restoration required more specialized skills, and PWA masons did the majority of this work (See Figures 15-21). The Branch of Plans and Designs measured the lock gates and wrote up specifications. Workmen built the lock gates at the National Capital Park offices and then sent to Fredericksburg, Virginia for high-pressured creosoting before the panels were installed. ${ }^{97} \mathrm{CCC}$ enrollees helped install the new lock gates, which used recycled hardware from old lock gates (See Figure 22). ${ }^{98} \mathrm{CCC}$ enrollees also helped in rebuilding the bypass flumes at Locks 15 and 16 (See Figures 23-26). These bypass flumes were done in concrete, a typical CCC material, and portions were covered with stacked logs to give an appearance of the original earth and log construction. ${ }^{99}$ This is an excellent example of where the CCC used nonhistoric materials and modern construction methods to improve efficiency, but still tried to make it look historic to fit within the general scene.

Another project that required collaboration from the Branch of Plans and Design, CCC, and PWA was the reconstruction of Stop Lock above Lock \#16 (See Figures 27-28). During

\footnotetext{
${ }^{96}$ Historic Photographs Collection, C\&O Canal National Historical Park, Hagerstown, MD.

97 "Workmen Fashion Canal Accessories," The Evening Star, June 20, 1939, Clip Files, C\&O Canal National Historical Park, Hagerstown, Maryland.

${ }^{98}$ For photos of CCC enrollees installing gates see Historic Photographs Collection, C\&O Canal National Historical Park, Hagerstown, MD. McGrew and Vint, "Outline Report of Architectural World on the Restoration of the Chesapeake and Ohio Canal for Recreational Use (Georgetown, D.C., to Seneca, MD)" (Washington, D.C.: National Park Service, Branch of Plans and Design, 1939).

${ }^{99}$ For photos of the concrete bypass flumes and CCC enrollees see Historic Photographs Collection, C\&O Canal National Historical Park, Hagerstown, MD. Lisa Pfeuller Davidson and James A. Jacobs, "Civilian Conservation Corps Activities in the National Capital Region of the National Park Service," (Washington, D.C.: Department of the Interior, Historic American Building Survey, 2005), 67.
} 
periods of high water, the Stop Lock diverted flood water back into the river. As mentioned before, the HABS field team travelled to Williamsport to record the existing Stop Lock there. Then the Division of Plans and Design developed measurements and specifications for the new Stop Lock above Lock \#16. Workers poured a concrete core wall over the old masonry core. The Division of Plans and Design designed a new building to house the original hoisting machinery from Dam No. 4. The building was to be covered in siding taken from a razed canal building to give it an "appearance of mellow age," although it was never completed."

While rewatering the canal was well underway, the Branch of Plans and Design considered the preservation of the canal's historic buildings. McGrew and Vint found some to be in reasonable condition, like Lockhouses 6 and 8, while others were beyond repair, such as Lockhouse 12. In considering the recreational development of the canal, they contemplated tearing down the old buildings and building anew, but they saw the utility in preserving the original character of the canal:

In reconditioning the canal for use as a recreational waterway, it would of course be possible to disregard its historical aspect and to replace the old structures with new ones. On the other hand, rehabilitation of the old structures relating to the canal as one operated will greatly diversify the recreation offered by the area, in that historical and educational exhibits of considerable cultural interest will thus be retained. Morevoer, the old structures are so typical of the forthright construction of a century ago and those of architectural character are so excellent in their simplicity and proportions that they well merit preservation. Preservation in their original settings, they are there for the visual enjoyment and inspiration of all who may have the good luck to see them. They are so much an integral part of the waterway and so completely assimilated into their surrounding by reason of decades of weathering that there can be no valid accusation that they compete with the natural beauties of the area or with the primary responsibility of providing a waterway affording active recreation. ${ }^{101}$

\footnotetext{
${ }^{100}$ McGrew and Vint, 20. For photographs of Stop Lock reconstruction see Historic Photographs Collection, C\&O Canal National Historical Park, Hagerstown, MD.

${ }^{101}$ McGrew and Vint, 4.
} 
This passage demonstrates that Vint and his Branch of Plans and Designs believed their primary responsibility was to provide a place of active recreation, reflection, and inspiration. They found these canal buildings to be organic to the landscape - rather than a distractionbecause of their age and simplistic design. They were essential in conveying the canal as "quaint" and "primitive," and reinforced the myth that life on the canal was simple and uncomplicated. In the context of the Great Depression, this myth appealed to a public generally disenchanted with the pitfalls of capitalism.

This approach allowed NPS architects to focus on the preservation on the exterior of the buildings as accessories in the landscape and take liberties in the interiors to make them modern. They took great pains to retain character defining features and often used documented materials at other buildings to recreate missing features at other buildings, such as door hardware. Examining the rehabilitation efforts at several lockhouses and Great Falls Tavern provides a better perspective of NPS preservation ethics during the New Deal.

During the winter of 1939 to 1940, the Great Falls area (located near Lock 19) was the focus of the development efforts. Traditionally, Great Falls has always been a popular destination for tourists, because of its proximity to the Great Falls of the Potomac. During the canal's operation, a lockhouse was expanded and later turned into a tavern and inn to accommodate these visitors. For the NPS, the preservation of Great Falls Tavern was critical, because of its nostalgic appeal, landmark potential, and proximity to a prime recreation zone. They intended to adaptively reuse the Tavern as a visitor center because of these appealing qualities. Photos of the dilapidated Tavern were featured in early newspaper reports announcing 
the impending restoration of the canal. ${ }^{102}$ To make the Tavern fit for occupancy, the NPS needed to repair the sills, joists, flooring, interior plaster, ceiling, wiring, exterior stucco, dormers, windows, fireplaces, stairs, and roof. They also needed to rebuild the porches on the rear of the building and on the east and west elevations. They removed a newer frame porch on the front façade and a newer wooden frame kitchen on the west elevation. ${ }^{103}$ The NPS razed the two frame structures, and planned for the restoration of the log cabin at Lock $20 .{ }^{104}$ However, the restoration of the log cabin was never undertaken and was later removed (See Figure 29). ${ }^{105}$

The first lockhouse to receive attention was Lockhouse 7, which was coincidentally the first house to be completed by the $\mathrm{C} \& \mathrm{O}$ Canal Company. At the time of the restoration, one corner had collapsed and been poorly rebuilt. New Deal workers took down the old repair work and rebuilt it properly. The interiors were gutted and reinstalled, along with new dormer windows and plumbing "for greater economy and comfort."106 The architects designed the dormer windows based off those found at Lockhouse 16, in a desire to create uniformity among the buildings. ${ }^{107}$

New Deal workers rebuilt Lockhouse 5, which was of frame construction on a stone foundation. They uncovered the frame and found it good condition, so they just rebuilt the

\footnotetext{
${ }^{102}$ Newspaper Clipping, "Great Falls Tavern to be Restored," 1938, Central Classified Files, RG-79, E-10, Box 2836, Folder A, NARA.

${ }^{103}$ White, As-Built Drawings, "Repairs and Alterations to Tavern," Branch of Design and Plans, June 16, 1939, National Park Service, National Capital Region, Drawings 412 Series.

104 McGrew and Vint, 40-45; Alston Gutterson, Drawings, “Alterations to Lock House at Lock 20," Branch of Design and Plans, 1939, National Park Service, National Capital Region, Drawings 412 Series.

105 Other lockhouses to have been rehabilitated include Lockhouses 11, 16, and 21. The restoration planned for these buildings are similar to the restoration work at the other lockhouses, including interior and exterior repairs and modernization. See McGrew, Drawings, "Alterations to Lock House at Lock 11," Branch of Design and Plans, October 10, 1939, National Park Service, National Capital Region, Drawings 412 Series; Irwin McClure, Drawings, “Alterations to Lock House at Lock 16," February 23, 1939; Drawings, "Alterations to Lock House at Lock 21," Branch of Design and Plans, 1939.

${ }^{106}$ McGrew and Vint, 26.

${ }^{107}$ McGrew and Vint, 21.
} 
exterior. However, they added two windows in the gable ends and dormers in the attic. They rearranged the interior "to provide the facilities now regarded as necessary to health and comfort," meaning they added a new kitchen and bathroom. The NPS also rebuilt the wooden porch, thereby recreating a character defining feature. ${ }^{108}$

New Deal workers repaired Lockhouse 10 in much of the same way as Lockhouse 7. They added a new kitchen and dormers. In the as-built drawings, a bathroom should have been added in the middle of the second story, between the two bedrooms. However, today the bathroom is located in the northeast corner of the second floor at the top of the stairs. Where the bathroom should have been located in the 1939 rehabilitation, is now a closet with the HVAC unit. The bathroom was finally added in 1959. These changes indicate that workers often changed or abandoned plans in the field. The Division of Plans and Designs found original hardware on the doors in the building, and used these specifications to replicate hardware for the other buildings. Workers repointed the stonework and the exterior was specified to be whitewashed. $^{109}$

The lockhouses were rehabilitated to possibly serve as concession stands (for "drinks and sandwiches"), or as homes for lockkeepers who might continue to operate the locks. ${ }^{110}$ The concession stand idea prompted a notable concept drawing of Lockhouse 22, in which a wood frame kitchen addition was attached to the east side of the lockhouse and picnickers strolled

\footnotetext{
${ }^{108}$ McGrew and Vint, 21. As-Built Drawings, “Lockhouse 5 Alterations,” July 27, 1939, National Park Service, National Capital Region, Drawings 412 Series.

${ }^{109}$ McGrew and Vint, 31. As-Built Drawings, “Lockhouse 10 Mechanical Drawings," 1939, National Park Service, National Capital Region, Drawings 412 Series.

${ }^{110}$ Map, W.M.H., "Map of the C\&O Canal to Seneca Showing Houses at Lock No's 5-23 Inc.," Branch of Design and Plans, June 12, 1938, National Park Service, National Capital Region, Drawings 412 Series.
} 
about the front lawn replete with picnic tables. ${ }^{111}$ This concept drawing is reminiscent of the picnic areas and RDA's developed by the CCC during the period, and actually the Branch of Plans and Designs suggested ten total picnic areas along the canal. ${ }^{12}$ Beyond using lockhouses as concession stands or respites for visitors, the NPS designed other structures to be built along the canal (although never undertaken), including several variations of Picnic or Hiker Shelters. One plan shows a shelter which loosely interprets the Lockhouse Type I style, with a central chimney. $^{113}$

The idea to keep the lockhouses as places of residences for lockkeepers stemmed from an issue facing the NPS upon acquisition of the canal. The federal government became landlord to approximately 180 tenants who lived on canal company land. ${ }^{114}$ While the NPS was unsure of the final use of the canal, they allowed the tenants to stay for a short period. It would have been disastrous public relations for the NPS and the Roosevelt Administration during the Great Depression to evict the families, many which were superannuated canal employees. ${ }^{115}$ Instead, the government took a paternalistic attitude to these residents, and actually hired the superannuated canal employees, some in their late-seventies and eighties, with PWA funds. A press release announced: "Uncle Sam smiled benignly on thirty-five employees of the old

\footnotetext{
${ }^{111}$ Concept Drawing, "Preliminary L.H. \#22," September, 28, 1938, Branch of Design and Plans, 1939, National Park Service, National Capital Region, Drawings 412 Series.

112 Map, "Suggested Picnic Areas along the Chesapeake and Ohio Canal," May 13, 1939, Branch of Design and Plans, 1939, National Park Service, National Capital Region, Drawings 412 Series.

${ }^{113}$ Drawing, "Picnic or Hikers' Shelter," February 29, 1940, Planning and Construction Division, National Park Service, National Capital Region, Drawings 412 Series.

114 Mackintosh, 21.

${ }^{115}$ For list of employees still on the C\&O Canal Company's payroll when acquired by the federal government, see "Regular Payroll of Employment," R. W. Young, R.S. B. Hartz, and G.L Nicholson, Receivers of Chesapeake and Ohio Canal Company, National Capital Region: Subject Files, RG 79, E-149, Box 50, “1439-50-50 Personnel-Foreman, etc." folder, NARA.
} 
Chesapeake and Ohio Canal Company today as notified them they were to continue their daily tasks along the canal which they may have tended for 40 or 50 years past."116

The former canal employees were valuable to the NPS because of their experience and technical skill in canal operations. Charles S. Jones, McKinley E. Hunt, Alton N. Jones, Charles S. Jones Jr., Harry A. Murray, and Horace T. Trammel performed maintenance duties between Georgetown and Little Falls. They mowed and repaired the towpath, mowed the canal prism, maintained the Little Falls Dam, and assisted in the building of a new lock gate. Julia King tended the feeder lock at Little Falls, near where she was living. Kate Violette continued as lock tender at Lock 23 in Seneca. Samuel E. Fisher, George W. Burgan, John F. Wine, Thomas M. Shiver, and Harry F. Sterling were the supervisors of the 3,4,5,6 and 7 divisions of the canal. The government retained them to protect government property and to assist in the lease and rentals of real property. William A. Kimble assisted Sterling in division 7. Some others worked as laborers. ${ }^{117}$ The renewed activity C\&O Canal also prompted an interest in "canal folk culture." Jess Swain, lockkeeper at Lock 21, reportedly played canal boat songs on his bugle at the National Folk Life festival in $1939 .{ }^{118}$

However, PWA funds were expended in 1940, and these positions were eliminated. Only Julia King and Charles S. Jones had positions extended. ${ }^{119}$ Nine former employees found employment elsewhere, but three former employees sought relief from local welfare boards and 14 remained unemployed and not on relief. Four of those unemployed were reported as being

\footnotetext{
116 Press Release, "Memorandum for the Press," Department of the Interior, National Park Service, Central Classified Files, RG 79, E-10, Box 2836, Folder B, NARA.

${ }^{117}$ Memorandum, Lawrence Murray to Frank T. Gertside, June 21, 1939, National Capital Region: Subject Files, RG 79, E-149, Box 50, “1439-50-50 Personnel-Foreman, etc." folder, NARA.

118 “Canalman Here to Play Bugle at Folk Fete," The Washington Post, April 18, 1939, 14, Clip Files, C\&O Canal National Historical Park, Hagerstown, Maryland.

${ }^{119}$ Memorandum, For the Acting Director, June 28, 1940, National Capital Region: Subject Files, RG 79, E-149, Box 50, "1439-50-50 Personnel-Foreman, etc." folder, NARA.
} 
supported by their families, since most of them were too old to obtain employment. ${ }^{120}$ Sydney S. Connell, who worked for the C\&O Canal for forty years, filed a grievance when his temporary PWA position was eliminated in 1940, because those that remained employed had fewer years of service. ${ }^{121}$ Maryland Senator Millard E. Tydings proposed a bill that year to be introduced to the $77^{\text {th }}$ Congress that would provide a pension for the men formerly employed by the C\&O Canal company with 25 years of service and were 65 years old or older. The NPS, although sympathetic to the former employees, did not support such a bill. ${ }^{122}$

The intended use of the lockhouses as concession stands or homes for lockkeepers gives a logical explanation why the lockhouses were modernized to include plumbing, kitchens, and dormers. It follows along Vint's desire to upgrade NPS facilities to meet visitor needs. It fits within a larger New Deal mission to modernize buildings in rural or depressed areas to raise the standard of living with an implicit emphasis on diet, health, and hygiene. ${ }^{123}$ A notable example is the New Deal subsistence homestead community, such as Arthurdale in West Virginia. These homestead communities sought to relocate impoverished families to planned communities in rural areas that featured decentralized industry. Each family had a house with all the modern amenities and sufficient acreage for a garden. These communities promoted better nutrition and

\footnotetext{
${ }^{120}$ Memorandum, M. McColligan to Gillen, January 22, 1941, National Capital Region: Subject Files, RG 79, E-149, Box 50, "1439-50-50 Personnel-Foreman, etc." folder, NARA.

${ }^{121}$ Letter, Robert H. Smith to Congressman William D. Byron, March 29, 1940, Central Classified Files, RG 79, E-10, Box 2838, Employment Folder; Letter, J. Atwood Maulding to Senator Millard E. Tydings, April 19, 1940, Central Classified Files, RG 79, E-10, Box 2838, Employment Folder.

${ }^{122}$ Memorandum, Acting Superintendent to Acting Director, December 31, 1941, National Capital Region: Subject Files, RG 79, E-149, Box 50, "1439-50-50 Personnel-Foreman, etc." folder, NARA.

${ }^{123}$ Melissa Walker discusses the New Deal kitchen improvement program, which targeted domestic households in the rural upcountry south to improve diet, health, and hygiene. See Melissa Walker, All We Knew was to Farm: Rural Women in the Upcountry South, 1919-1941 (Baltimore: The Johns Hopkins University Press, 2000), 109-110, 118-119, 122.
} 
often provided access to better healthcare. In return, individuals were expected to contribute to the community. ${ }^{124}$

The desire to create recreational facilities for the new C\&O Canal park also promoted a healthy, active lifestyle. Vint and his staff put in hours to design canoe or boathouses and rendered several design concepts. Great Falls was the main focus of recreational activities. Renderings of the Tavern included several different floor plans that allowed for segregated public restrooms, concession stand, and dining room. One rendering included a wing extended north off the Tavern for open air dining, promenade, and canoe dock. Another rendering shows an old mule barn adaptively re-used as a canoe house. A general development plan for the Great Falls area also shows a separate boat house with a dock just slightly upstream from the Tavern, with a promenade in between. This boat house included restrooms, dining, and canoe storage. The façade looks much like the front façade of the Tavern. ${ }^{125}$ Today there is a small concession stand in the vicinity that was built in the $1950 \mathrm{~s}$, but it does not match the scale and function of this proposed design. ${ }^{126}$ The Great Falls Tavern also did not see significant floor changes like in some of the concept drawings. The issue of bathroom facilities was answered however in 1940 when the CCC built a comfort station behind the Tavern. NPS architects tastefully designed the comfort station in simple board and batten to fit the historic landscape. ${ }^{127}$

\footnotetext{
${ }^{124}$ For more on New Deal community programs and Arthurdale, see Paul Conkin, Tomorrow a New World: The New Deal Community Program (Ithaca, New York: Cornell University Press, 1959) and Bryan Ward, A New Deal for America: Conference on New Deal Communities (Arthurdale, West Virginia: Arthurdale Heritage, Inc., 1995). ${ }^{125}$ Drawing, "Great Falls General Development Plan," Branch of Design and Plans, 1939, National Park Service, National Capital Region, Drawings 412 Series; Drawing, McClure, "C\&O Canal Canoe House \& Conc. At Great Falls Maryland," August, 15, 1939, Branch of Design and Plans, National Park Service, National Capital Region, Drawings 412 Series.

126 "Great Falls Tavern Cultural Landscape Report," National Capital Region Cultural Landscapes Program (Washington, D.C.: National Park Service, September 2009) 24.

${ }^{127}$ As-Builts, H.C. May, "Great Falls Toilet," July 2, 1940, Planning and Construction Division, National Park Service, National Capital Region, Drawings 412 Series.
} 
The reason why Vint's development designs, such as the canoe house, were never carried out is unknown. The C\&O Canal project exhausted most of the original PWA funds in 1940. There may also have been a change of heart for the designers on how far they were willing to change the landscape. Historian T. Sutton Jett apparently put up some opposition with other design plans that came as a detriment to the historical landscape. ${ }^{128}$ World War II, however, put a definite pause on the $\mathrm{C} \& \mathrm{O}$ Canal project as manpower and resources were needed for the war effort. America's entry into the war is the most likely reason why some of these larger schemes were never undertaken, although it is important to note that the rehabilitation of the waterway from Georgetown to Seneca— the central feature of the rehabilitation project—was completed.

While there were concerns about the possibility of a parkway, there did not seem to be any overt criticisms of the $\mathrm{C} \& \mathrm{O}$ Canal rehabilitation project. However, some citizens did express discontent regarding the natural preservation along the canal and Potomac River. First, it is necessary to explain that mankind has impacted the ecology of the Potomac River Valley for thousands of years, first with Native peoples and then European settlers. Canals became popular during the Enlightenment, because they demonstrated man's ability to perfect nature. The construction and operation of the C\&O Canal had impacted the ecology of the Potomac River Valley for over a century, first by building an artificial waterway directly adjacent to the river, and then having to keep a distance on either side of the canal clear of any trees. Vegetation had to be kept clear between the towpath and the prism so that a canal boat's towline would not get caught. The C\&O Canal Company also had to keep a distance on either side of the canal clear of trees. If a tree were to fall in the canal it would block the waterway.

\footnotetext{
${ }^{128}$ Mackintosh, 38.
} 
However, two hikers who encountered the CCC's work clearing the canal prism, which re-vegetated after the canal ceased operations, called it "appalling." They reported that the CCC cut down trees over large areas and have taken all sizes for firewood. ${ }^{129}$ In response to the hikers' accusations, Yellowstone Superintendent Edmund B. Rogers, who was in Washington on detail, was sent to investigate the camps. He found that the camps were practicing proper environmental conservation. They did not even burn wood-just coal. ${ }^{130}$ On June 7, 1939, Assistant Wildlife Technician E. L. Green, Jr. met with the C\&O Advisory Committee (Cabin John Citizens Association) to show them the canal development. The CCC had cleaned up the canal up from Great Falls to Swain's Lock, and the group expressed concern over a section that had been cleared above the waterline on the berm bank. They felt this was entirely unnecessary, since the area had no recreation function. ${ }^{131}$ A biology professor from American University expressed concern that rewatering the canal would obliterate "the best aquatic animal and plant communities close enough to Washington for his students to study." He hoped that some shallow places would be left untouched for further study. ${ }^{132}$

These concerns indicate a growing awareness and concern for environmental preservation, and the public's desire to maintain the natural features of the canal. Immediately, these concerns curtailed the CCC's vegetation removal, setting the precedent for allowing vegetation to grow closer to the canal-more so than it would have been historically. In the longer term, these sentiments set the precedent for future environmentalists who in the 1950 s set

\footnotetext{
${ }^{129}$ Letter, W. M. Pomeroy to Collier, December 5, 1938, National Capital Region: Subject Files, RG-79, E-149, Box 40, “1439-25 ECW \#4" folder, NARA.

${ }^{130}$ Memorandum, Edmund B. Rogers to Director, December 10, 1938, National Capital Region: Subject Files, RG79, E-149, Box 40, “1439-25 ECW \#4” folder, NARA; Memorandum, A.E. Demaray to Collier, December 12, 1938.

${ }^{131}$ The CCC has been criticized by environmentalists for destroying natural areas in order to carry out other projects. See Maher, 3.

132 Memorandum, E.L.Green, Jr., June 12, 1939, National Park Service, Department of the Interior, Central Classified Files, RG 79, E-10, Box 2836, Folder C.
} 
out to save the remaining 162 miles of canal for its natural, recreational, and historical qualities. $^{133}$

In its transition to a park, the first 22 miles of the C\&O Canal were shaped by three competing visions: recreational development, historic preservation, and natural preservation. It is useful to look at two other comparable New Deal park projects, which also struggled with these same competing visions, to see how the C\&O Canal project is unique. First, the state of Illinois purchased the Illinois and Michigan Canal after operations ended in 1933. Five CCC companies worked from 1933 to 1938 transforming the canal into a recreational amenity for Starved Rock State Park. Recreational development was very much a driving factor in this instance. CCC enrollees created a complex of recreational sites along I\&M Canal Parkway, which followed the canal's towpath. The CCC cleared debris from the canal like at the C\&O Canal, and also rehabilitated some of the historic locks and lockhouses. However, they also built numerous structures, including bridges, shelters, and lodges. ${ }^{134}$ Although further research is required, it is apparent at a cursory glance that the development of I\&M Canal was a precedent for the activities at the $\mathrm{C} \& \mathrm{O}$ Canal. However, the expansion of the built environment far exceeded anything planned or completed at the $\mathrm{C} \& \mathrm{O}$ Canal. This may have occurred because this was a state park and there was less of a concern for historic preservation. The C\&O Canal probably received more emphasis on historic preservation than I\&M Canal because the project occurred with the maturation of the NPS History Program and HABS, and was close to these offices in Washington, D.C.

\footnotetext{
${ }^{133}$ Supreme Court William O. Douglas completed a protest hike in 1956 with a group of environmentalists, historians, and newspaper editors to stop the building of a parkway. For more information about their efforts to save the canal, see Mackintosh and Adam Sowards, The Environmental Justice: William O. Douglas and American Conservation (Corvallis: Oregon State University Press, 2009).

${ }^{134}$ Dennis Cremin and Charlene Giardina, Starved Rock State Park: The Work of the CCC along the I\&M Canal. Images of America (Chicago, IL: Arcadia Publishing, 2002).
} 
Great Smokey Mountains National Park was established in 1934 to create a kind of "Yellowstone of the East" - meaning a natural wilderness east of the Mississippi River closer to Eastern populations. The NPS had to restore the wilderness to lands that were formerly settled through the process of secondary succession. They ran into trouble with Cades Cove, a community established in the early nineteenth century and still occupied when the NPS acquired the land in 1937. Cades Cove was a popular tourist destination for those wishing to see the "primitive" features of pioneer life. The NPS decided to keep certain historic structures, such as $\log$ cabins, but razed other frame structures since they did not lend themselves to the primitive, pioneer image. Geographer Terence Young explores an agricultural permit system that was instituted in 1945 to allow modern farmers to operate on historic landscapes and keep the views open. However, Young believed this decision led to decades of ecological degradation at the expense of aesthetics and economy. Here again it is evident that the NPS struggled to find a compromise between historic preservation, scenic preservation, and recreational development, which tremendously altered the landscape and took it far from local memory of how the landscape used to look. In Young's view, it was altered for the worse. ${ }^{135}$

Another flood in 1942 undid a substantial amount of the work completed by the CCC and PWA at the C\&O Canal. The long interim between when the canal actually became a National Historical Park in 1971 also meant that deferred maintenance was ongoing —at least for the first 22 miles. The remaining 162 miles left untouched during the first restoration efforts was largely left to go back to nature. Noting the difference between the first 22 miles and the rest of the canal shows that a significant precedent was established between 1938 and 1942. This precedent called

\footnotetext{
${ }^{135}$ Terence Young, "False, Cheap and Degraded: When History, Economy and Environment Collided at Cades Cove, Great Smoky Mountains National Park, Journal of Historical Geography 32(2006), 169-189. For a longer history on Cades Cove that also discusses the changes wrought by the National Park Service, see Durwood Dunn, Cades Cove: The Life and Death of an Appalachian Community, 1818-1937 (Knoxville: University of Tennessee Press, 1988).
} 
for the restoration and preservation of the waterway for recreational purposes. The "re-branding" process of the $\mathrm{C} \& \mathrm{O}$ Canal as a recreational entity had been started and a substantial initial investment made. When portions of the canal were reopened after the war, it served its function as being a place to recreate, reflect, and find inspiration. It inspired Supreme Court Justice William O. Douglas to call for the canal's preservation in 1954, when the idea of a parkway was renewed.

The New Deal was a turning point in the historic preservation field and the preservation and interpretation of the C\&O Canal. The federal government through the NPS entered the business of preserving historic sites as it continues today. The transition of the NPS from just scenic preservation in the West to include historic preservation in the East during the 1930s reveals that park planners struggled to find a balance between recreational development, historic preservation, and natural preservation. The $\mathrm{C} \& \mathrm{O}$ Canal presents an interesting case study, because it is one of the first historic preservation projects undertaken by the federal government in which historical research was closely tied to its development. It is also an early example of how the NPS struggled to strike a balance between historic preservation, natural preservation, and recreational development. NPS research technicians and HABS surveyors worked to identify a period of significance for the canal and document its historic structures, which in turn informed the work of the Branch of Plans and Design, CCC, and PWA. The CCC and PWA were successful in rewatering the first 22 miles of the canal and restoring the towpath for canoeists and hikers to enjoy. The Branch of Plans and Design saw the utility in preserving these canal structures, because they were an organic part of the landscape and contributed to the "quaint" and "primitive" qualities of the canal. Planners faced criticism from concerned citizens who 
wished to see the natural beauty of the canal preserved, even though it took the canal away from how it looked historically. 


\section{CHAPTER FOUR}

\section{The Men in Green ${ }^{136}$}

The previous chapter discussed the historical actors that were involved in the research and planning of the preservation work at the C\&O Canal during the Great Depression. This chapter focuses on the workers who physically altered the C\&O Canal from a transportation system to a park - specifically the efforts of two African American Civilian Conservation Corps companies - and how their experience adds another dimension to this cultural production. It also shows that such a project impacted the lives of CCC enrollees by providing temporary employment, training, skills, and education. However, African Americans in the CCC faced challenges because of their race, including the disproportionate number of African Americans enrolled in the program compared to native born whites, the types of jobs they were trained for, and how they were treated by military officers and local communities. Their experience reveals inequalities of the New Deal and the reality of segregated American society during this period.

The two CCC companies provided the unskilled labor necessary to rewater the first 22 miles of the canal, by clearing the canal prism and restoring the towpath. Although the official reports characterize the CCC's work at the C\&O Canal as conservation work, there were essentially undertaking historic preservation projects. Chapter Two describes more fully the amount of research that occurred before these projects took place. The fact that these projects were well researched in order to retain the historic qualities of the canal demonstrates that the $\mathrm{CCC}$ enrollees were doing more than recreational development, even if their work was menial

\footnotetext{
${ }^{136}$ This title is borrowed from Michael Hoak's thesis on African Americans in the CCC in Virginia.
} 
labor. Their work projects were characterized in conservation terms primarily to ensure that the work stayed within the legislation that created the CCC: Emergency Conservation Work Act. However, the CCC Director's annual reports started including briefs on historic conservation work that the $\mathrm{CCC}$ was undertaking across the country. This expansion of the conservation definition allowed more diverse projects, including historic preservation as the National Park Service History Program was expanding. The CCC restored 3,980 historic structures.

Denise Meringolo asserts that CCC enrollees were frequently a test audience in developing National Parks. At Mesa Verde, for example, NPS staff and consignment operators provided tours and recreational activities for $\mathrm{CCC}$ enrollees. They aimed to develop enrollees as future tourists and recreationists, and encourage them to return to National Parks after they finished their enrollment. NPS historians used these enrollees as an indicator of the "phantom audience," or those American tourists they were developing their public history programs for and hoped to make into better citizens. ${ }^{137}$

The enrollees at the $\mathrm{C} \& \mathrm{O}$ Canal, however, were much more than just an audience. They were integral actors in the first public history programming at the $\mathrm{C} \& \mathrm{O}$ Canal. When the $\mathrm{C} \& \mathrm{O}$ Canal Recreational Waterway was opened for visitors, the NPS fabricated a canal barge for visitor tours, making it one of the first NPS living history programs. ${ }^{138}$ NPS Historian Thomas Sutton Jett gave the first interpretive tours on the canal boat rides. Historic photographs and newspapers, however, show that CCC enrollees were involved in all other aspects of canal boat operations. They led the horse that pulled that boat (even though mules were historically used),

\footnotetext{
${ }^{137}$ Denise Meringolo, "Turning Nature into History: The Professionalization of Public History in the National Park Service," Dissertation-George Washington University (2005), 193.

${ }^{138}$ Barry Mackintosh, Interpretation in the National Park Service: A Historical Perspective (Washington, D.C.: Department of the Interior, National Park Service, 1986), Chapter Three-Living History, accessed February 26, 2011, http://www.cr.nps.gov/history/online_books/mackintosh2/directions_living_history.htm.
} 
manned the bow, and operated the locks. ${ }^{139}$ By learning these skills, they perpetuated a historical occupation. The enrollees did not give verbal tours of the canal, but only through their demonstrations could visitors understand how a canal operated. In this pageantry of the past, the $\mathrm{CCC}$ enrollees were the actors on stage. However, the assignation of the African American enrollees to these more menial duties reinforced their position in segregated America.

The two African American CCC companies assigned to the C\&O Canal comprised twothirds of the African American CCC companies that worked in the entire National Capital Region during the corps's existence. This seems an extraordinarily low number considering that there were over 324 CCC camps in the region in 1938, employing over 52,000 men. ${ }^{140}$ However, these statistics reflect prevailing racial attitudes during the Great Depression and New Deal.

The unemployment and underemployment crises of the Great Depression were acutely felt by minorities. African Americans struggled more to find jobs than native born whites. Employers fired African Americans first_ prompting the adage "Last hired, first fired." As white male workers lost their jobs, they often took more menial jobs from African American or women workers. Despite promises to alleviate the unemployment crisis without discrimination, New Deal programs continued to discriminate against minorities in the same manner as what was

\footnotetext{
${ }^{139}$ Scott Hare, "Reminiscing-Or Barging through the C\&O Canal," The Washington Post, July 21, 1941, "1941 Folder," Clips Files, C\&O Canal National Historical Park, Hagerstown, Maryland; "Barging along the C\&O Canal," The Sunday Star, July 27, 1941; "Excursion Days on the Old Canal," The Baltimore Sun, August 11, 1941, p. 14; "Old C\&O Canal Throbs with Life Again; 40 Enjoy Voyage on Horse-Drawn Barge," Times-Herald, July 21, 1941.

${ }^{140}$ L.P. Davidson and J. A. Jacobs, "Civilian Conservation Corps Activities in the National Capital Region of the National Park Service," (Washington, D.C.: Department of the Interior, Historic American Building Survey, 2005) 12, 14.
} 
occurring in the private sector. ${ }^{141}$ FDR's make-work programs largely benefited white males. Small proportions of African American men were able to find employment through these programs, but women were mostly kept from them. The CCC is a notable example, since it was designed to only serve young males, and only a small proportion of which were African American.

An emerging body of scholarship has started to illuminate the African American experience in the CCC - arguably the most popular of all New Deal programs. ${ }^{142}$ The CCC is fondly remembered for its remarkable conservation efforts and the positive benefits it gave unemployed youth during the worst economic crisis in the country's history. However, as these scholars point out, the benefits were far from equal and very uneven, despite the amendment that said "no discrimination shall be made on account of race, color, or creed." "143 African Americans were admitted into the $\mathrm{CCC}$ on a less frequent basis, even though they sometimes outnumbered their white counterparts on local relief rolls. The camps were segregated, and enrollees often faced derisiveness from white officers and hostility from local communities, at least initially.

Two and a half million men served in the CCC from 1933 to 1942, and 250,000 were African Americans. The responsibility of selecting the men fell upon the Department of Labor. In the haste to put 250,000 men in the field in a matter of months in 1933 , the Department of

\footnotetext{
${ }^{141}$ Michael Hoak notes that the one exception is the PWA, which sought to ensure a fair deal for African Americans by hiring them on a proportion to the 1930 Occupational Census. Michael Hoak, "The Men in Green: African Americans and the Civilian Conservation Corps, 1933-1942," Thesis: College of William and Mary (2002). ${ }^{142}$ A few notable examples include Olen Cole Jr., The African-American Experience in the Civilian Conservation Corps (Gainesville: University Press of Florida, 1999); John A. Salmond, "The Civilian Conservation Corps and the Negro," The Journal of American History 52 (1965), 75-88; Calvin W. Gower, "The Struggle of Blacks for Leadership Positions in the Civilian Conservation Corps: 1933-1942," The Journal of Negro History 61 (1976), 123-135; Ann Burkly, "Blacks in the CCC: Successful Despite Discrimination," Proceedings and Papers of the Georgia Association of Historians 14 (1993), 37-45; Charles Johnson, "The Army, the Negro and the CCC: 1933-1942," Military Affairs 36 (1972), 82-88; Hoak.

${ }^{143}$ This amendment was made by the sole black member of the House of Representatives, Oscar DePriest, a Democrat from Illinois. Hoak, 11.
} 
Labor decentralized the selection process by relying on state and local relief agencies to enroll the men and then report back to the Department of Labor. CCC Director Robert Fechner set quotas for each state based approximately on the corresponding percentage of the number of men on state relief rolls to the rest of the country. These quotas were given to the state, and then dispersed among the various counties and towns. The reliance on state and local officials to choose men for the program allowed local discrimination to prevail. ${ }^{144}$ Early on in the selection, reports from the South indicated that local appointing officials were preventing African American applicants from enrolling in the CCC. For example, officials in Georgia did not enroll a single African American for almost an entire year until W. Frank Persons, the national selecting official for the Department of Labor, threatened to withhold the state's entire enrollment allotment. Only then did Georgia officials reluctantly accept a few token African Americans. ${ }^{145}$ In 1935, Fechner placed a cap on the number of African American enrollees by allowing their admittance only on a replacement basis. ${ }^{146}$

The task of mobilizing and running the CCC camps fell to the War Department because of its expertise in mobilizing large companies of men. Just as the military was rigidly segregated during this period, so were the CCC companies and camps. Initially, the companies were integrated, but dissent from local communities and the Army prompted Fechner to segregate the companies. Fechner had little problem with moving or dissolving African American companies if the local community did not want an all African American company there $\cdot{ }^{147}$ Oftentimes, local communities were willing to have an African American company near their community if all the

\footnotetext{
${ }^{144}$ Hoak, 13.

${ }^{145}$ Hoak, 14-15; Cole, 14; and Salmond, 77.

${ }^{146}$ Hoak, 18.

${ }^{147}$ Fechner is characterized as a Southern racist by most scholars studying African Americans in the CCC, including those scholars cited in this chapter.
} 
skilled positions went to local whites and they were commanded by white officers. ${ }^{148}$ According to Charles Johnson, "The Decision to use white officers had deep roots in Army tradition, reinforced by experience during World War I. Whether or not it represented an accurate assessment of actual wartime events, it had become conventional wisdom in the army that black troops performed well only when officered by whites." ${ }^{\text {149 }}$ The African American companies were commanded by white officers until dissent from African American leaders led to the establishment of an all African American company at Gettysburg in $1935 .{ }^{150}$ The company at Gettysburg was little more than a propaganda tool, since it really did not influence larger numbers of African American officers in African American companies, and of course African Americans could not serve as officers in white companies.

In the most extreme cases, ill treatment from white officers or hostility from local communities prompted African American enrollees to refuse to work or riot. Thomas Patton describes an incident at an African American camp at Preston Hollow in upstate New York. The enrollees refused to work when they learned that two African American clerks would be replaced with white counterparts. Six of the protest leaders were imprisoned, and 34 were discharged. ${ }^{151}$ Hoak also describes an incident that occurred in January 1934 in Yorktown, Virginia, which resulted in a narrowly averted race riot when a young white girl said "a large black man" severely injured her brother, and locals began harassing the camps. The accusation was unfounded, but tensions were heightened as mutual distrust existed between the CCC companies

\footnotetext{
${ }^{148}$ Hoak, 3.

149 Johnson, 84.

150 Joseph M. Speakman, At Work in Penn's Woods: The Civilian Conservation Corps in Pennsylvania (University Park, PA: The Pennsylvania State University Press, 2006), 142.

${ }^{151}$ Thomas W. Patton, “A Forest Camp Disgrace: The Rebellion of Civilian Conservation Corps Workers at Preston, New York, July 7, 1933," New York History 82 (July 2001): 231-258.
} 
and the local community. ${ }^{152}$ The more common method to protest the discriminatory practices in the camps, however, was simple refusal to work or desertion.

Despite the obstacles faced by African American CCC enrollees, they were largely "successful despite discrimination," as they generally benefited from the basic opportunities given to white enrollees. ${ }^{153}$ They were paid thirty dollars a month, twenty-five of which was sent home to their families. They had a roof over their heads, appropriate clothing, and an ample amount of food. They received valuable vocational training and marketable skills, although they were sometimes relegated to more menial duties than white enrollees. The institution of the education program enabled African American enrollees to take night classes in a wide range of subjects to advance their education. Recreation activities combined with physically demanding work and proper diet strengthened their bodies, as well as their minds. Further, they developed valuable social skills from living in the camps and working with other enrollees. Many enrollees had never lived away from home before, and certainly not with so many other men their age.

The CCC established two camps at the C\&O Canal in the summer and fall of 1938. The official records indicate that the CCC established MD-NP-1 on September 19, 1938, but other documents place the men's arrival between June 15 and $18 .{ }^{154}$ It was located at Carderock and occupied by Company 325-C. The company was commanded by Edwin T. Arnold, First Lieutenant Cavalry Reserves who had served in the CCC for over a year prior to coming to the canal. ${ }^{155}$ Approximately half a mile downstream was the location of Camp MD-NP-2, which was

\footnotetext{
${ }^{152}$ Hoak, 63-67.

153 Borrowing from the title of an article by Ann Burkly.

154 Letter, C. Marshall Finnan to Conrad L. Wirth, June 27, 1938, National Capital Region: Subject Files, RG-79, E149, Box 40, “1439-25 ECW \#4" folder, NARA.

${ }^{155}$ Harold G. Chafey, "Camp Inspection Report, NP-1-MD," October 13, 1939, Civilian Conservation Corps, Division of Investigation: Camp Inspection Reports, RG 35, E-115, Box 94, "Maryland NP-1, Montgomery County Folder," NARA.
} 
established on October 5, 1938 and occupied by Company 333-C. This company was commanded by Captain E.D. Wilberger, who had been in CCC service for nearly four years before arriving at the canal. The strength of both companies was around 180 men. ${ }^{156}$ Because of their proximity and the nature of their work, both companies often worked together as one unit. The two camps were located at the mid-section of the project area for the canal's restoration, closest to the highest concentration of locks and lockhouses.

Tension surrounded the establishment of Camp MD-NP-1, and an African American company was almost prohibited. NPS officials in the National Capital Region were already unhappy that they had to transfer an African American company from NP-4 to NP-6, because there were accusations that the community did not want an African American company there. Park Service officials had no evidence of these protests and alluded that it came from the War Department, which seemed ready to move a company or dissolve it when there was any indication of community dissent. Further, Park Service officials believed that junior African American enrollees had better discipline and conduct than white enrollees, and that any dissent was unfounded. ${ }^{157}$

Camp Navy-1-MD, an African American company located at Indian Head, MD, was terminated on May 31, 1938. This company was supposed to be transferred to MD-NP-1, but the Maryland Governor failed to designate another site. The War Department followed procedures established by the CCC Director dated September 25, 1937, "Modification of War Department Policy re: formation and location of colored CCC units.” Montgomery County Commissioners

\footnotetext{
${ }^{156}$ Ross Abare, “Camp Inspection Report, NP-2," August 26, 1939, Civilian Conservation Corps, Division of Investigation: Camp Inspection Reports, RG 35, E-115, Box 94, "Maryland NP-2, Cabin John Folder," NARA. ${ }^{157}$ Letter, Stanton G. Smith to C.P. Russell, August 5, 1938, National Capital Region: Subject Files, RG-79, E-149, Box 40, "1439-25 ECW \#4" folder, NARA.
} 
were allowed to comment on the placement of an African American company at Carderock, which they rejected. ${ }^{158}$ However, NPS officials argued that community consent was not needed to place an African American CCC company on federal land, and the Army eventually agreed. ${ }^{159}$ Camp MD-NP-1 was established in June, although the canal was not formally acquired by the federal government until September.

To get to the camps, one had to cross the canal prism, since they were situated between the canal and the river. Historic photographs and records indicate that they were typical CCC camps, comprised of portable buildings. Visitors to Camp MD-NP-1 first saw a T-shaped Mess Hall. Behind the Mess Hall were four large and one small barracks for enrollees. Just below the barracks were the Recreation Hall and Education Building. In the center of camp was the NPS office and communication center. Adjacent to the NPS office were living quarters for officers and NPS personnel. On the far east side of the camp, were four garages, a repair shop, a blacksmith shop, and a storehouse. Camp MD-NP-2 was comprised in a similar manner. However, when Company 333 first arrived they slept in tents by the canal waiting for the camp to be finished. Both camps were electrified and had pit toilets. They received water from a water storage tank. Septic went into the Potomac River and garbage was hauled off by a local pig farmer. ${ }^{160}$

\footnotetext{
${ }^{158}$ Letter, J.K. Parsons to Adjutant General, June 3, 1938, National Capital Region: Subject Files, RG-79, E-149, Box 40, "1439-25 ECW \#4" folder, NARA; Letter, Ira C. Whitacre to Major General J.K. Parsons; Letter, Herbert Evison to Board of County Commissioners, June 6, 1938, National Capital Region: Subject Files, RG-79, E-149, Box 40, "143925-50 Personnel (Foremen, etc.) ECW \#2" folder, NARA.

${ }^{159}$ Letter, Stanton G. Smith to C. Marshall Finnan, June 16, 1938, National Capital Region: Subject Files, RG-79, E149, Box 40, "1439-25 ECW \#4" folder, NARA; Telegram, War Department, June 9, 1938.

${ }^{160}$ Drawing, "General Plan Camp Carderock NP 1 MD C.C.C. Company 325 Cabin John MD," January 5, 1940, National Capital Parks, National Park Service, 412 Drawings Series; Records Concerning Abandoned Camps, 19341944, RG 79. E-119. Box 2, Folder “MD-NP-2," NARA; Historic Photographs Collection, C\&O Canal National Historical Park; "Historical Records of CCC Camp Buildings: NP-1-MD," 1939, Historical Record of CCC Camp Buildings, RG-77, E-395, Box 1, NARA; “Historical Records of CCC Camp Buildings: NP-2-MD,” 1939.
} 
Although the Army provided the camps, the CCC enrollees were encouraged to make the camps their own. ${ }^{161}$ They spent significant time improving and beautifying the camp. James

Carey wrote about the improvements made at Camp NP-MD-2 since he arrived at the camp:

In comparison with the growth of a child so has the beauty of the camp grown. Where we once had bare patches of clay we now have grassy lawns. The barracks once rough and unfinished now are painted with attractive colors. The roads around camp were overcrowded with tall grass and baby trees, but now there is no more wilderness around the camp roads. The roads have been leveled and gravel has been spread in the place of the weeds that once grew there. ${ }^{162}$

Despite the work put in by the enrollees, sometimes the bureaucratic order put a damper on their activities. A camp investigator reported that the enrollees had done all the work to create concrete walks at Camp NP-MD-1, but the requisition for cement was disapproved by the Corps Area. ${ }^{163}$

Company 325 was likely a new company when it was established at the C\&O Canal, despite the fact that the number was formerly used at the Navy-1 at Indian Head, MD. ${ }^{164}$ Company 333, however, had a history. It was originally established at Camp C-NF-15 at Columbia Furnace, VA on the West Virginia-Virginia border on May 14, 1933. It began as a white unit, but was re-designated as a colored unit in August 1934. At Columbia Furnace, the company improved timber stands on 16,000 acres; constructed 45 miles of road; completed 60 miles of horse trails; installed 100 miles of telephone lines; undertook roadside naturalization of

\footnotetext{
${ }^{161}$ CCC administrators encouraged CCC enrollees to improve their camps to improve morale, instill a sense of pride and stewardship, encourage teamwork, and discourage idleness. This is discussed in the CCC Handbook, where the author describes a group of enrollees that decided to spruce up the ugly mess hall. Ned H. Dearborn, Once in a Lifetime: A Guide to the CCC Camp (New York: Charles E. Merrill Company, 1935), 226.

162 James Carey, "Camp Improvement," Tow-Path Journal 2, June 30, 1939.

${ }^{163}$ Ross Abare, "Camp Inspection Report: NP-1," February 27-28, 1941.

${ }^{164}$ In the CCC Third Corps Area District No. 31937 Official Annual, there is listed a Company 325 comprised of African Americans. This camp was located at Navy-1, Indian Head, Maryland. However, none of the officers named in the Annual match those listed at the canal. It is likely that this camp was dissolved, and a new camp located at the C\&O Canal and the company number appropriated. See Official Annual. Civilian Conservation Corps Third Corps Area District No. 3. (Direct Advertising Company, 1937), 38-41.
} 
50 miles; and undertook three miles of stream improvement. The company continued to maintain 80 miles of road and protected 100,000 acres of forests from fires. They fought fires at Cedar Creek for three days in the fall of 1935, and assisted in flood recovery after the 1936 flood. After 38 months at Columbia Funace, the company transferred to Wilderness, VA on October 11, 1937 to do battlefield restoration work at the Civil War site. During this time, Director Robert Fechner spent Thanksgiving dinner with the company. On October 4, 1938, the company was transferred to Maryland for the "rebuilding of the Ohio and Chesapeake Canal.","165

Both camps expended a sum of 158,700 man hours from 1938 to 1942 . The bulk of the man days went towards the restoration of the canal prism and towpath, which required a substantial amount of unskilled labor. First, CCC enrollees cleared 200 acres of vegetation from the canal bed. Then they excavated 50,700 cubic yards of earth from the canal prism and helped restore 22 miles of towpath. They hand placed 9,835 square yards of stone rip rap for bank protection, dry masonry walls for bypass flumes adjacent to locks, and along the towpath at Widewater. These projects alone formed the core of the canal's rehabilitation and transformation into a recreation entity. They were involved in other historic preservation work, including razing two undesirable frame structures at Great Falls. They also assisted in the rehabilitation of Great Falls Tavern and several lockhouses. Additionally, they built a 1.5 mile long water bound macadam road and an access road to the US Engineers Garage, which they also built. At Great Falls, the CCC enrollees built a latrine, sewage and waste disposal system, and a filtration plant.

\footnotetext{
${ }^{165}$ Official Annual, 122-123; William Allen, "A Brief History of the $333^{\text {rd }}$ Company, CCC," The Tow-Path Journal, March 31, 1939, 11.
} 
Finally, they also performed typical CCC services, such as forming emergency search parties, snow removal, and fire suppression. ${ }^{166}$

More skilled positions went to the technical personnel in the CCC or WPA workers. CCC technical personnel included project foremen, carpenters, engineers, mechanics, clerks, plumbers, heavy equipment operators, and landscape architects. Historian and wildlife technicians also appeared on the roll. ${ }^{167}$ The technical personnel helped guide the CCC enrollees in their projects. WPA workers were hired as carpenters, masons, mason's tenders, granite cutters, stonecutters, blacksmiths, truck drivers, auto mechanics, and general laborers. ${ }^{168}$ The enrollees worked with WPA workers who performed most of the building rehabilitation and masonry work (restoring the locks and other structures).

Initially, the Emergency Conservation Work Act did not include any education program for CCC enrollees other than on the job training. However, pressure from educators, state selection agencies, and FDR — all of which saw the educational potential of the CCC - prompted the creation of the Corps Educational Program just a few weeks after the ECW Act was signed. The Program was administered by the War Department, but received assistant from the Office of Education, which was then included in the Department of the Interior. Eventually, Educational Advisors were assigned to camps to develop camp curriculum and serve in an advisory capacity

\footnotetext{
${ }^{166}$ Robert Coates, "Inventory of Work Accomplished by the CCC Camps Under the Jurisdiction of the National Capital Parks, October 19, 1933 to January 1, 1942," National Park Service, January 15, 1942, National Capital Region: Subject Files, RG-79, E-149, Box 44, "Progress Reports" folder, NARA.

${ }^{167}$ Ross Abare, "Camp Inspection Reports: NP-1," 1938-1942, Civilian Conservation Corps, Division of Investigation: Camp Inspection Reports, RG 35, E-115, Box 94, "Maryland NP-1 Montgomery County Folder," NARA; Ross Abare, "Camp Inspection Reports: NP-2," 1938-1942, Civilian Conservation Corps, Division of Investigation: Camp Inspection Reports, RG 35, E-115, Box 94, "Maryland NP-2 Cabin John Folder," NARA.

168 Memorandum, Acting Assistant Superintendent to Acting Director, September 12, 1939,
} 
to help enrollees find jobs. Essentially they functioned as both school teacher and guidance counselor. ${ }^{169}$

The initial and prevalent fear of appointing African Americans to supervisory positions in the CCC kept them from serving as Educational Advisors in their own camps. However, members from the African American community (who also advocated African Americans to serve in any supervisory position) were especially adamant that African Americans be appointed to Educational Advisor positions in African American camps. As Michael Hoak points out, the desire for African Americans to be in charge of their own educational curriculum kept true to the racially segregated public school system. In fact, the strategy of the NAACP during this time was not to attack the legality of segregation, but to challenge its legality as it was practiced - showing that educational opportunities for African Americans in segregated states were nowhere near equal. ${ }^{170}$ In May 1934, the first fourteen African Americans were assigned as Educational Advisors. By 1940, all but a few companies had African American Educational Advisorsmarking a sizable achievement in the struggle of African Americans for leadership positions in the CCC. ${ }^{171}$

Educational Advisors at African American camps had a substantial task at hand. Howard Oxley, the Director of CCC Camp Education, wrote that many of these enrollees came from "underprivileged homes and communities which offer few opportunities." He gives data from 1938, the same year as the two C\&O Canal CCC camps were established: 7.6 percent of African American enrollees are illiterate when they enter the camps; 53.7 percent are at the elementary

\footnotetext{
${ }^{169}$ Olen Cole, 46-48.

${ }^{170}$ In Michael Hoak's second chapter, he gives an interesting case study of the development of the educational program at Yorktown. The first African American educational program was developed at Yorktown and he argues that it originated by local African American elites (with the backing of the Hampton Institute) who were determined to improve the education of the enrollees. Hoak, 38.

${ }^{171}$ Cole, 48. See also Calvin Gower.
} 
school level; 33.5 percent are at the high school level; and 5.2 percent have completed high school or attended college. He added that nearly two-thirds of these enrollees had no previous vocational training. ${ }^{172}$ Oxley reported that the primary education object for African Americans was the elimination of illiteracy, and 91.8 percent of illiterates were receiving training. The second objective was to remove common school deficiencies, since most employers required an elementary school education. Over half of the elementary level enrollees took classes to improve skills such as arithmetic and grammar. Students who had high school education could take advanced courses, including courses at nearby universities. There were of course classes to help with job employability and vocational training. Oxley reported that "specialized training" had been organized for CCC enrollees, including "cooking, table-waiting, mess management, barbering, laundering, tailoring, typing, bookkeeping, and store management." ${ }^{173}$ However, one educational advisor complained that it was difficult focusing enrollees towards jobs they were suitable for, such as "janitors, chauffeurs, table waiters and helpers," when they really wanted white collar positions-which just were not available. ${ }^{174}$

The official records indicate that camps NP-MD-1 and 2 were very active in their education programs. The camp library at NP-MD-1 had over 700 books, and an extension had to be made to the building in 1939. The classes offered at this camp included English, penmanship, athletics, music, carpentry, First Aid, handcrafts, civics, journalism, history, science, sign painting, painting, leaders' training, typewriting, building and estimating, blasting and dynamite, masonry and concrete, auto mechanics, surveying, landscaping, camp administration, health education, safety, current events, mess, and camp discipline, which were supplemented with

\footnotetext{
${ }^{172}$ The average enrollee was only 19 years old. Howard W. Oxley, "The Civilian Conservation Corps and the Education of the Negro," Journal of Negro Education 7 (July 1938), 377.

${ }^{173}$ Oxley, 377-379.

${ }^{174}$ Oxley, 381.
} 
forums and lectures. ${ }^{175}$ The Educational Advisor, technical personnel, camp officers, WPA instructors, and even enrollees taught these classes, which were offered three nights a week. Educational films were shown twice weekly and feature films once a week. The August 1939 report says that attendance was approximately fifty percent.

Camp NP-MD-2 also had a library that boasted over 700 books and magazines, even receiving "20 issues of Happy Days." It reportedly was nicely furnished with chrome leather chairs, settees, chrome smoking stands, floor lamps and attractive pictures on the walls. Classes offered at the camp included reading and writing, current events, history, hygiene, penmanship, practical English, practical mathematics, world affairs, typing, commercial art, carpentry, journalism, trail canal excavating, canal drainage, truck driving, cooking, dramatics, music, model making, social courtesy, First Aid, safety, health, teacher training, foreman training, and leader training. Classes were throughout the work week. A 1939 report said that average daily attendance was about 34 men out of 172. Eighty-four men were also certified in First Aid. ${ }^{176}$ Camp NP-MD-2 had the benefit of C. Rushton Long, an African American college graduate and the Educational Advisor that had been with Company 333 before its arrival at the canal. The camp newspaper, The Tow-Path Journal, wrote emphatically about the successes of the company's education program. ${ }^{177}$ "Education Notes" in The Tow-Path Journal, reported that through Long's efforts, enrollees were able to attend classes at area high schools and Phelps Vocational School. Editor Frank White added, "There is a wonderful opportunity for every boy in camp to learn something worthwhile."178

\footnotetext{
${ }^{175}$ Ross Abare, Camp Investigation Report: NP-1," August 25, 1939.

${ }^{176}$ Ross Abare, Camp Investigation Report: NP-2," August 25, 1939.

${ }^{177}$ There are only two known editions of this camp newspaper.

${ }^{178}$ Frank White, “Educational Notes," The Tow-Path Journal 1, March 31, 1939.
} 
The newspaper also reported the addition of WPA instructress Pansy Williams in 1939, a graduate of Howard University. Howard University had a Bureau of Educational Research, which edited the Journal of Negro Education. The journal aimed at the collection and dissemination of facts about African American education; presenting discussions on proposals and practices relating to their education; and sponsoring investigations into problems incident to their education. ${ }^{179}$ Williams taught African American history, practical mathematics, reading, writing, and English at the camp. The Tow-Path Journal reported that the majority of her classes were crowded, and alludes that it was because of her appearance. ${ }^{180}$ This may have been true, but it might also reflect the enrollees' desire to have classes tailored to their interests, notably the addition of African American history to the curriculum. ${ }^{181}$ Miss Williams apparently had a favorable impression of the CCC enrollees, writing "I find that men are after all considerate, cooperative, thoughtful and even willing to have a woman tell them a thing or two."182

C. Rushton Long and A. F. Williams, the Education Advisors at Camps NP-MD-1 and 2, both believed that the education programs at both camps were successful, and spoke in glowing terms of the progress made at their respective camps. Long reported:

A great number of enrollees have entered camp with no objective in life and with a spirit of defeatism, but after being exposed to the camp's general training opportunities for a period of time those same men have not only developed their educational vocational and occupational skills but they have developed a wholesome perspective and attitude on life. Numerous case histories can be cited of enrollees who have conquered illiteracy, others have erased common school deficiencies, others have developed vocational skills, some have broadened their occupational possibilities, some have secured jobs, and some have made a success

\footnotetext{
179 Journal of Negro Education 7 (July 1938).

${ }^{180}$ Frank White, "Educational Notes," The Tow-Path Journal 2, June 30, 1939.

${ }^{181}$ Hoak asserts that CCC enrollees at Yorktown asked for more African American history classes after the Superintendent taught a history course focusing on the American Revolution. Hoak, 47.

182 Pansy Williams, "My Impression of Youth in a CCC Camp," The Tow-Path Journal 2, June 30, 1939.
} 
in college and trade schools all of which is the result of some inherent factor or force found in the Camp's Educational and Training Program. ${ }^{183}$

Besides educational courses, the enrollees could participate in a variety of recreational activities. Swimming was popular among enrollees at a nearby YMCA. Camp MD-NP-2 had a baseball field, and barracks formed teams to play against each other. Together as a camp, they called themselves the "Triple Threes." 184 Company 333 also had a basketball team, which played rival camps, such as Beltsville. The players had uniforms and sweatshirts with the company's number. ${ }^{185}$ Enrollees could also take part in informal activities such as pool, ping pong, card games, checkers, and darts. Dances were occasionally held, and the enrollees could participate in twice weekly recreational tips to Washington, D.C. ${ }^{186}$ Company 333 enrollees competed in horseshoe and track tournaments at the YMCA.

While their minds and bodies were shaped by their work, classes, and recreational activities, CCC enrollees also had access to spiritual growth. "Spiritual Advisors" visited the camps every week to hold discussions and Bible classes. Chaplain William B. Marsh, Chaplain Roberts, and Reverand Walter Toms of Washington, D.C. visited Company 333. Chaplain Marsh was in the Army Reserves. ${ }^{187}$

Despite the initial obstruction by the Montgomery County Board of Commissioners, there were no known instances of hostile community relations with these two CCC camps. The only instance found in the records is a complaint letter sent from Maurice Salsbury who accused CCC enrollees from stealing his boat. Salsbury kept his boat under the watch of William Davis, a resident lockkeeper. Salsbury wrote: "On leaving your Camp we proceeded down along the river

\footnotetext{
183 Ross Abare, “Camp Investigation Report: NP-2,” August 25, 1939.

${ }^{184}$ Amos Custis, "Sports," The Tow-Path Journal 2, June 30, 1939.

185 Thomas Christain, "Sports," The Tow-Path Journal 1, March 31, 1939.

${ }^{186}$ Ross Abare, “Camp Investigation Report: NP-1" and “Camp Investigation Report: NP-2," March 1, 1941.

187 John Gholson, "Religion," The Tow-Path Journal 1, March 31, 1939
} 
bank and from Mr. Swainson at Seven Locks, Maryland, we learned that the boat was seen the past Sunday, May $7^{\text {th }}$, filled with colored men, in the uniform of the Civilian Conservation Corps, going down the river, that lacking oars the boat was grounded on the rocks near Glen Echo and were rescued." 188

According to official records, the camps seemed to be rather successful for the first two years. However, a memo in the files indicates that conditions were less than superior in 1941. Camp Investigator Ross Abare made this report of Camp MD-NP-1 by phone: "Report that mess is not properly balanced, especially breakfast; camps were found to be unclean; morale of boys not good; the lights in the barracks were inadequate; many of the sockets empty."

Later that year in July, an anonymous letter was sent to the Director of the CCC: "Dear Sir: I want you to know what you should know, the way things is going at camp 325 . The foreman is drinking if this does not stop we will all be hurt.” CCC Special Investigator Ross Abare believed that the letter was written by Charles W. Williams of Germantown, Pennsylvania. Williams enrolled in May 1941 in Philadelphia, was assigned to Company 325, and was selected to understudy the PX Steward. After two works of unsatisfactory work, he was assigned to a field work crew. In June, a hearing was held for Williams for refusal to obey orders and was punished to 16 hours weekend duty. A few days later, he refused to take orders from the Project Engineer and received another 16 hours of weekend duty. The next day, Williams tried to physically assault the man who replaced him as understudy with a brick. He was stopped, but at bed check it was discovered that Williams went AWOL. Abare believed that Williams sent the

\footnotetext{
${ }^{188}$ Letter, Maurice Salsbury to CCC Commanding Officer at Carderock, May 18, 1939, National Capital Region: Subject Files, RG-79, E-149, Box 41, "1439-25-50 Personnel (Foremen, etc) \#2" Folder, NARA.

${ }^{189}$ E.W.McC., "Memorandum," February 27, 1941, Division of Investigation: Camp Inspection Reports, RG-35, E115, Box 94, "Maryland NP-1 Montgomery County Folder," NARA.
} 
letter when he went AWOL. Abare discounts the letter's accusations because of the trouble Williams caused. ${ }^{190}$ However, even if the accusations were unfounded, the letter may reveal a general tension between the supervisors and the enrollees.

The camps also suffered from a recurrent problem that existed throughout the CCC, which marred its otherwise outstanding record: high rates of desertion. The year 1939 was the worst year for desertion in the CCC. Robert Fechner told his advisory council that this rate of desertion "was the worst spot on the whole record of the camps" and that it was damaging the CCC's public image. ${ }^{191}$ By 1939, the desertion rate was twenty percent, meaning that one out of five men left the camp illegally. Fechner blamed new camp officers who exhibited weak control over the enrollees and misunderstood the nature of the work. However, this excuse did not explain the sharp rise of desertions that occurred between 1937 and 1939, or the fact that almost twice as many 18 year olds deserted as did 17 year olds, and that 19 year olds left at an even higher rate. ${ }^{192}$

The Selection Division implemented a study on the desertion issue between 1937 and 1940. They found no singular reason or cause, but several. Most state selection officials found that the reasons for desertion stemmed from either bad camp administration or that enrollees were ill-prepared for camp life. Some stated that enrollees were given a false impression of camp life and left when it failed their expectations. Many cited homesickness as the biggest factor, which was something they could not help. The Selection Division also found that the mounting tensions overseas kept men from enrolling, fearing that they might be drafted to fight. The war

\footnotetext{
${ }^{190}$ Letter, Ross Abare to Charles Kenlan, July 7, 1941, Division of Investigation: Camp Inspection Reports, RG 35, E115, Box 94, "Maryland NP-1 Montgomery County Folder," NARA.

${ }^{191}$ Quoted in John A. Salmond, The Civilian Conservation Corps, 1933-1942: A New Deal Case Study. Durham, North Carolina: Duke University Press, 1967: accessed June 28, 2010, www.nps.gov/history/online books/ccc/salmond.

${ }^{192}$ Salmond.
} 
situation also prompted the Army to remove its best officers for regular service. There was also the argument that the quality of the enrollees had dropped by this point, since many of the quality enrollees and young men were finding positions in the improving economy. ${ }^{193}$

In late August 1939, Special Investigator Ross Abare found an abnormal discharge rate at Company $325 .{ }^{194}$ Between July 1938 and June 1939, 89 men left honorably before the end of their term; 100 were charged with administrative desertion; 36 discharged for administrative or other causes; 5 had dishonorable discharges, and 73 left and the end of their enrollment. ${ }^{195}$ His report launched an investigation of discharges from the company between May to August 1939. The investigator reported that "these discharges were due in the main to inadaptability to camp life of the individual enrollees concerned" and that there were "no unusual circumstances which have contributed to a high rate of discharge."

The investigator showed that there were few cases of homesickness, but wrote that many men left because they did not like the work or camp life. The reasons the investigator gives seem tinted with racial stereotypes. In the case of James Briscoe, the investigator noted: "It is reported by the Proj. Supt. that Briscoe did not like his job in the field and could not be pleased." In the case of John Risby, he noted: "This enrollee was a very shiftless sort of person and took no interest in camp work or life and it is reported he deserted to avoid work in the field." The investigator called Raymond Smith "lazy" and that he "most likely deserted to keep from working." The investigator also noted several cases where enrollees were taken out of positions to work in the field. Rather than working in the field, they deserted. ${ }^{196}$ These desertions may be

\footnotetext{
${ }^{193}$ Salmond.

194 Letter, Charles Kenlan to Adjutant General War Department, September 21, 1939.

${ }^{195}$ Ross Abare, “Camp Inspection Report: NP-1,” August 25, 1939.

${ }^{196}$ Roy A. Wisler, "Investigation Report: Camp NP-1, Company 325, Cabin John, Maryland," November 1, 1939.
} 
viewed as the CCC presented them — a simple inability to adapt to work and camp life—or they may be viewed as a critique to camp authority that the African American enrollees were not happy with life in the CCC. ${ }^{197}$

The issue of desertions marred the record of the camps at the C\&O Canal, but they hardly defined it. Success can be shown through the substantial amount of work completed in the restoration of the C\&O Canal. Success can also be gleaned from the glowing reports of the Educational Advisors. Unfortunately, few primary sources are available that give the CCC enrollee's perspective of the measure of success of their experience at these camps. However, a speech made by Company 333 enrollee Carl Palmer during commencement gives a sense of optimism for life after the CCC: "After overcoming the obstacles that have confronted us in life, I look into full consideration the opportunities that has been at our door in the Civilian Conservation Corps. Assuring myself that every one of you have taken full advantage of these, I believe that you are well equipped to fight life's battle." ${ }^{, 198}$ Their experiences in the CCC also gave them optimism in the progression of their race. ${ }^{199}$

Camp MD-NP-2 closed in November 1941, and its buildings were slated to be used for the war effort. After the United States entry into World War II, Camp MD-NP-1 was converted into NP(D) 3 in April 1942. These defense camps converted the CCC's work from conservation to the development of the military infrastructure and protection of resources. Camps lost their non-military character and enrollees began receiving training that would be useful for war efforts. Even before Camp MD-NP-1 was converted into a defense camp, enrollees could take

\footnotetext{
${ }^{197}$ It is interesting to note that the editors of The Tow-Path Journal, like many camp newspapers, used their medium as a podium to implore enrollees to obey orders, cooperate with camp administration, work as a team, and ultimately achieve an honorable discharge.

${ }^{198}$ Carl Palmer, "Farewell Address," The Tow-Path Journal 1, March 31, 1939.

${ }^{199}$ Claiburn Pink, "Negroes and the P.W.A.," The Tow-Path Journal 1, March 31, 1939.
} 
defense classes, such as auto mechanics, carpentry, electricity, sheet metal work, welding, and aviation mechanics. ${ }^{200}$ For example, a photograph of enrollees at NP(D) 3 show them in an automotive repair class. The camp continued to serve as a defense camp until July 1942 when Congress formally ended the Civilian Conservation Corps.

From 1938 to 1942, the historic preservation work required at the C\&O Canal employed hundreds of men - most of them African Americans. Understanding their experiences in the $\mathrm{CCC}$ and during this era gives special meaning to the work they completed. Their work not only set a precedent for the future preservation of the C\&O Canal, but provided many of the men with new skills and opportunities to foster their future growth.

${ }^{200}$ Ross Abare, “Camp Inspection Report: NP-1-MD,” February 2, 1942. 


\section{CHAPTER FIVE}

\section{Conclusion}

Rehabilitation activities at the $\mathrm{C} \& \mathrm{O}$ Canal ended in 1942 as quickly as they had begun. The Public Works Administration expended its funds and Congress did not renew the Civilian Conservation Corps. A flood in 1942 obliterated sections of the towpath that the CCC repaired. Congress did not allocate any funds to maintain the nascent park. The country was fighting a global war and the Army and Navy declared the Great Falls and Widewater area of the canal a military reservation, and were not reopened until after the war. ${ }^{201}$

The C\&O Canal did not become a National Historical Park until 1971. However, the years from 1938 to 1942 were critical to the formation of the C\&O Canal as a park, and set a precedent for its later development. The federal government made the initial acquisition and investment in the first 22 miles of the C\&O Canal, which resulted in a substantial commitment to provide recreational opportunities for generations to come. Park planners considered historic preservation as a critical component to the park's development, and struggled with competing interests in natural preservation and recreational development. This struggle sheds light on the first period of federal historic preservation efforts.

A perfect storm of cultural movements, including Progressivism, natural conservation, recreation, and American tourism, influenced the preservation decisions made at the C\&O Canal.

\footnotetext{
${ }^{201}$ Letter, Frank Gertside to Sergeant Bailey, May 25, 1944, “Canal (\#2) 1941-1949” Folder, CHOH Historic Resource Files; Letter, Jean Stephenson to Irving Root, December 11, 1945; Letter, Irving Root to Jean Stephenson, December 18, 1945.
} 
New Deal programs enabled the federal government to purchase the canal to provide work for skilled and unskilled workers in need of relief. The canal was an ideal project because it fit well within FDR's progressive conservation ethic and other progressive cultural movements like the recreation and American tourism movements. The canal's acquisition occurred concurrently as the National Park Service expanded east of the Mississippi and into the field of historic preservation and public history.

In the case of the $\mathrm{C} \& \mathrm{O}$ Canal, historic preservation was a critical component to maximizing the recreational potential of the new park. HABS architects and NPS historians performed historical research in tandem with the rehabilitation of the canal prism, towpath, locks, and historic structures. However, park planners also tried to "stop the clock" at the canal, and razed a few historic structures and removed additions at Great Falls Tavern. At the same time they modernized historic buildings with dormers, electricity, new kitchens, and plumbing, and developed amenities for visitors. They envisioned the canal as a place for canoeists and hikers to enjoy both its natural and historical qualities. During this development phase, park planners also faced criticism from concerned citizens who did not support the parkway or believed the NPS was removing too much vegetation. These voices foreshadow the post-war environmental movement that saved the canal from becoming a parkway, and allowed the remaining 162 miles to be reclaimed by nature. Today, these two sections appear to be two different parks, and neither replicate the historic canal.

This initial preservation phase was made possible by New Deal programs, which provided work for skilled and unskilled workers on relief. The third chapter more fully explores the social history of the two African American CCC companies that provided the unskilled labor necessary to rehabilitate the canal. This chapter recognizes these men as important cultural 
producers who contributed to the transformation of the park. Inversely, their work at the park transformed the lives of the enrollees. Through the CCC, these men were able to acquire on-thejob experience, skills, and education that would benefit them later in life during a desperate time in American history. In the case of the C\&O Canal, we also see some of the hardships faced by African Americans in the CCC. The Montgomery County Board of Commissioners originally did not want an African American company at MD-NP-1, and a high desertion rate was found at the camps.

After becoming a National Historical Park, the $\mathrm{C} \& \mathrm{O}$ Canal still continues to be at the forefront of National Park Service historical preservation efforts. The NPS Historic Preservation Training Center was first established at Cushwa Basin in Williamsport, and used many structures along the C\&O Canal as training for preservation masons and carpenters. ${ }^{202}$ These NPS employees have undertaken preservation projects all over the country.

${ }^{202}$ HPTC is currently located in Frederick, Maryland. 


\section{PHOTO APPENDIX}

All photos, with the exception of Figures 3 and 4, are courtesy of the Historic Photograph Collection, C\&O Canal National Historical Park in Hagerstown, Maryland.

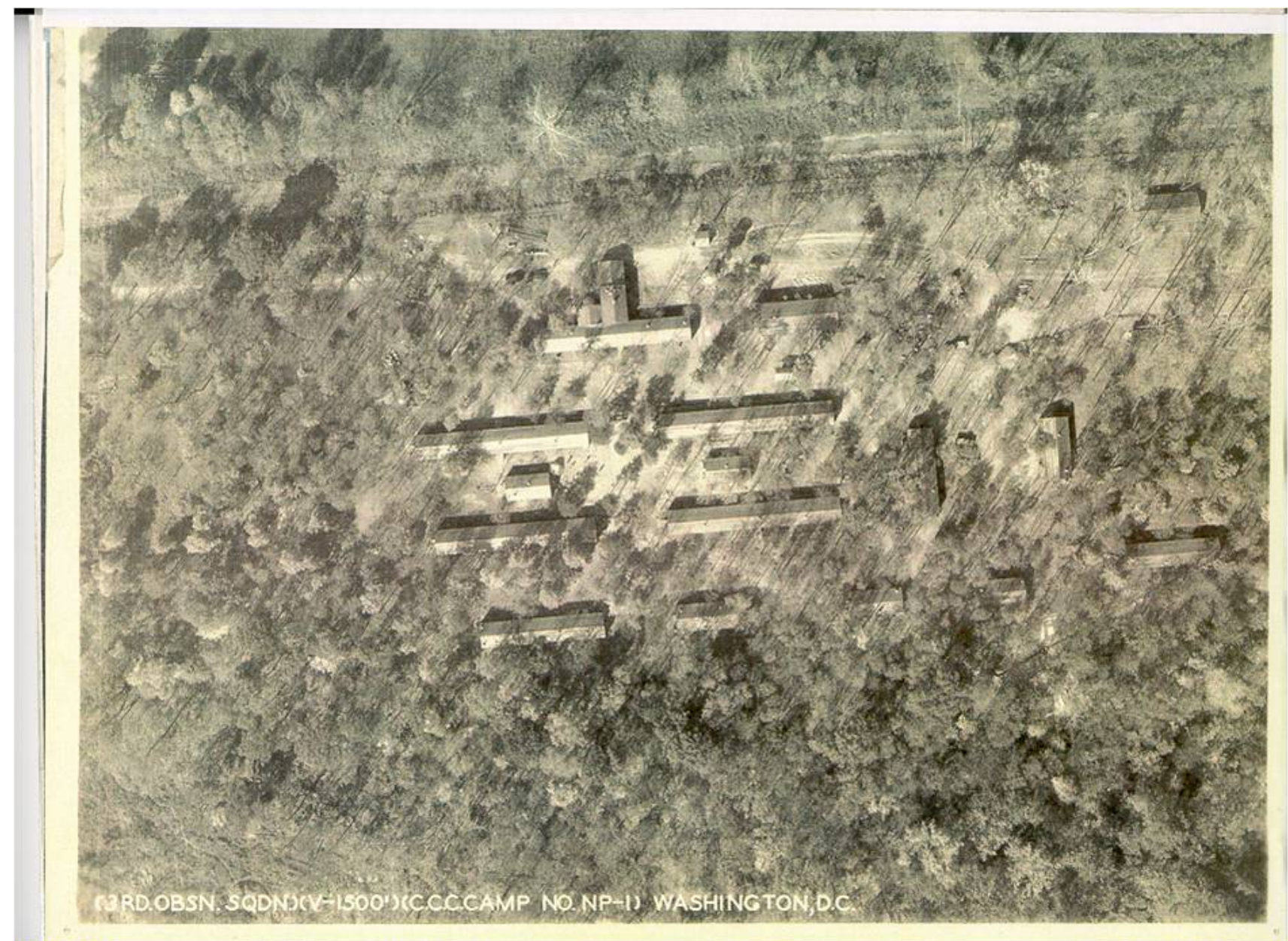

Figure 1: Aerial of Camp MD-NP-1 


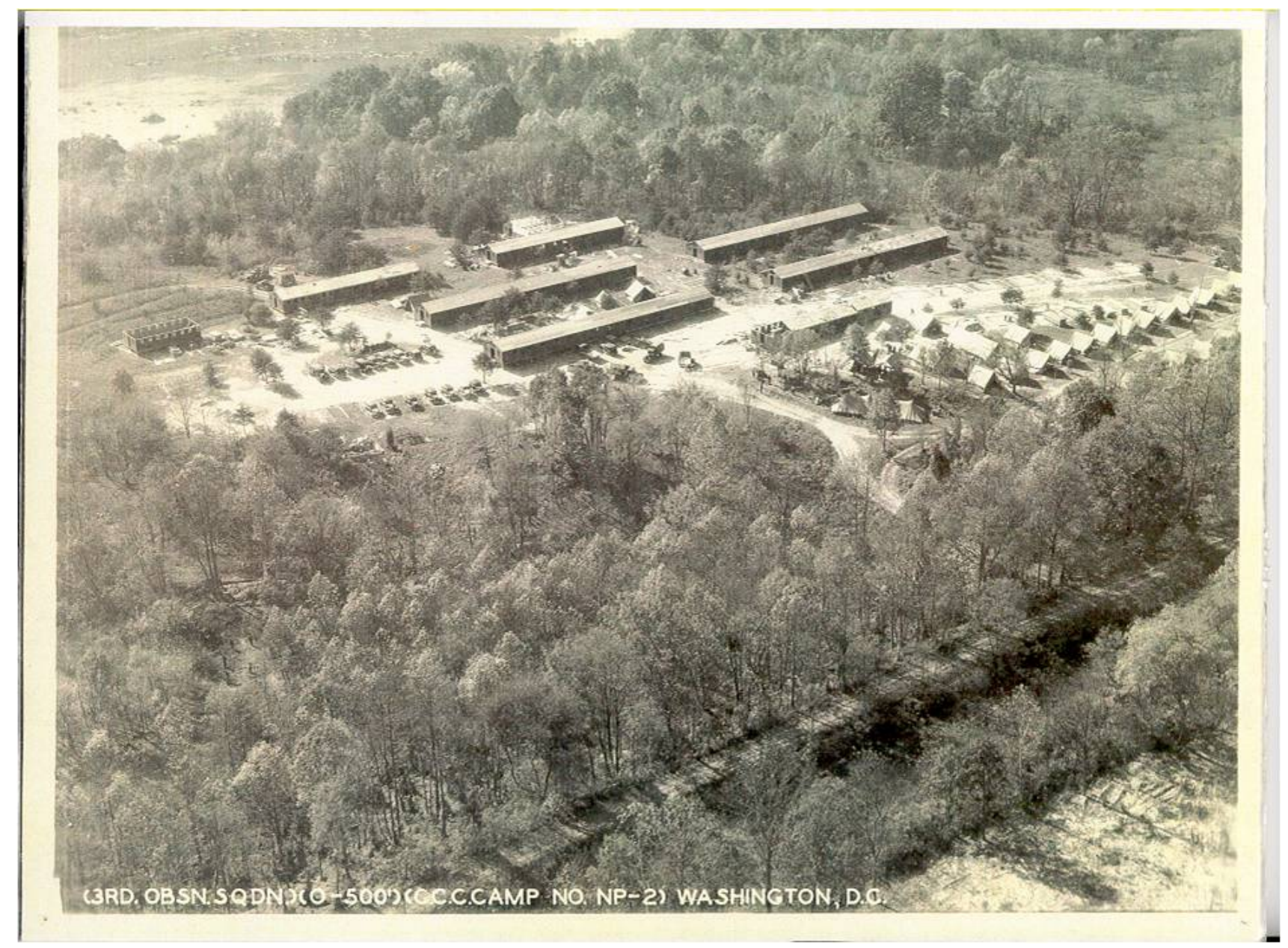

Figure 2: Aerial of Camp MD-NP-2 


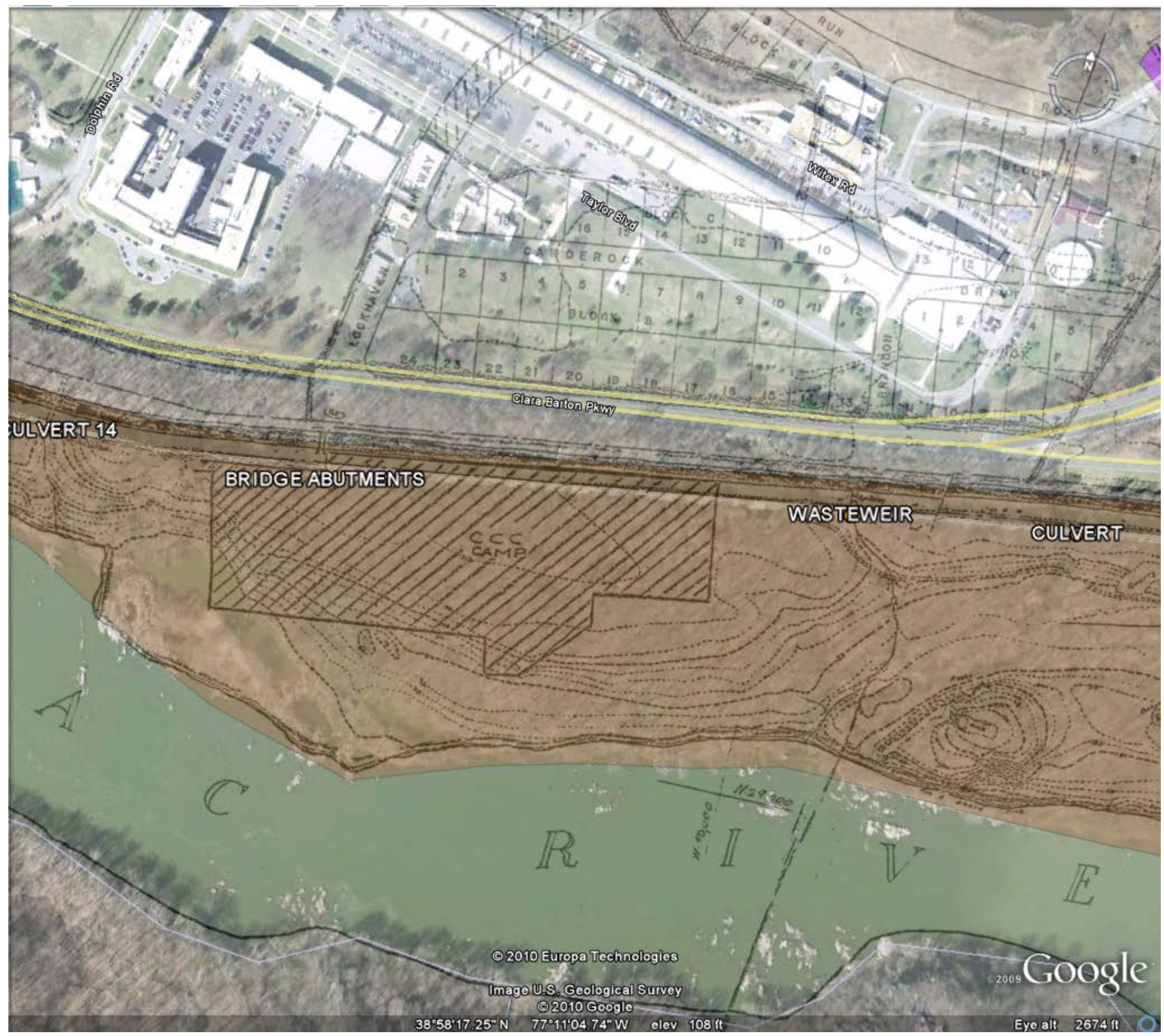

Figure 3: Historic map overlay on Google Earth showing location of Camp MD-NP-1. The map is located in the National Park Service, National Capital Region 412 Drawing Series, and is also courtesy of the C\&O Canal National Historical Park in Hagerstown, MD. 


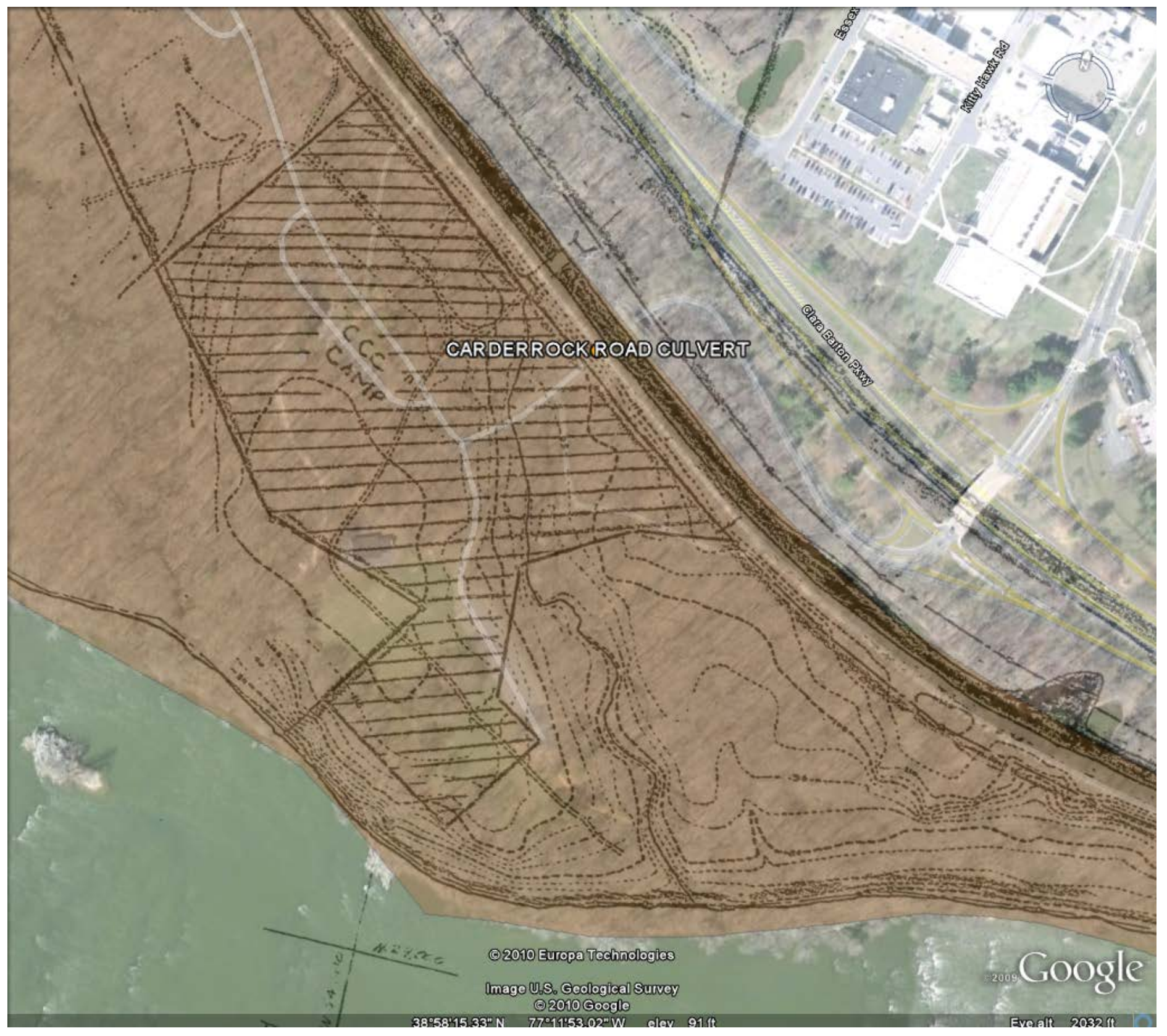

Figure 4: Historic map overlay on Google Earth showing location of Camp MD-NP-2. The map is located in the National Park Service, National Capital Region 412 Drawing Series, and is also courtesy of the C\&O Canal National Historical Park in Hagerstown, MD. 


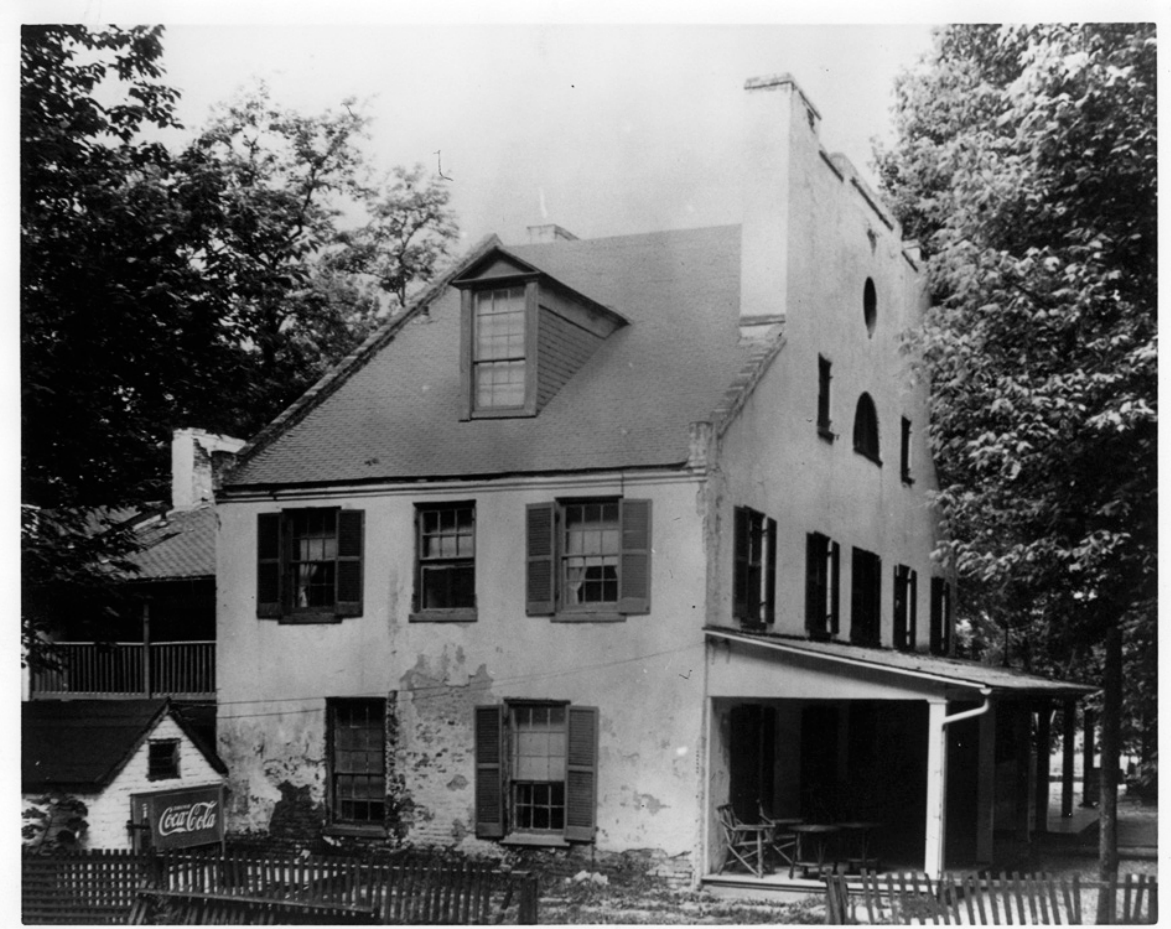

Figure 5: Great Falls Tavern photographed by John Bostrup, HABS Photographer, August 6, 1936. New Deal workers removed the front porch.

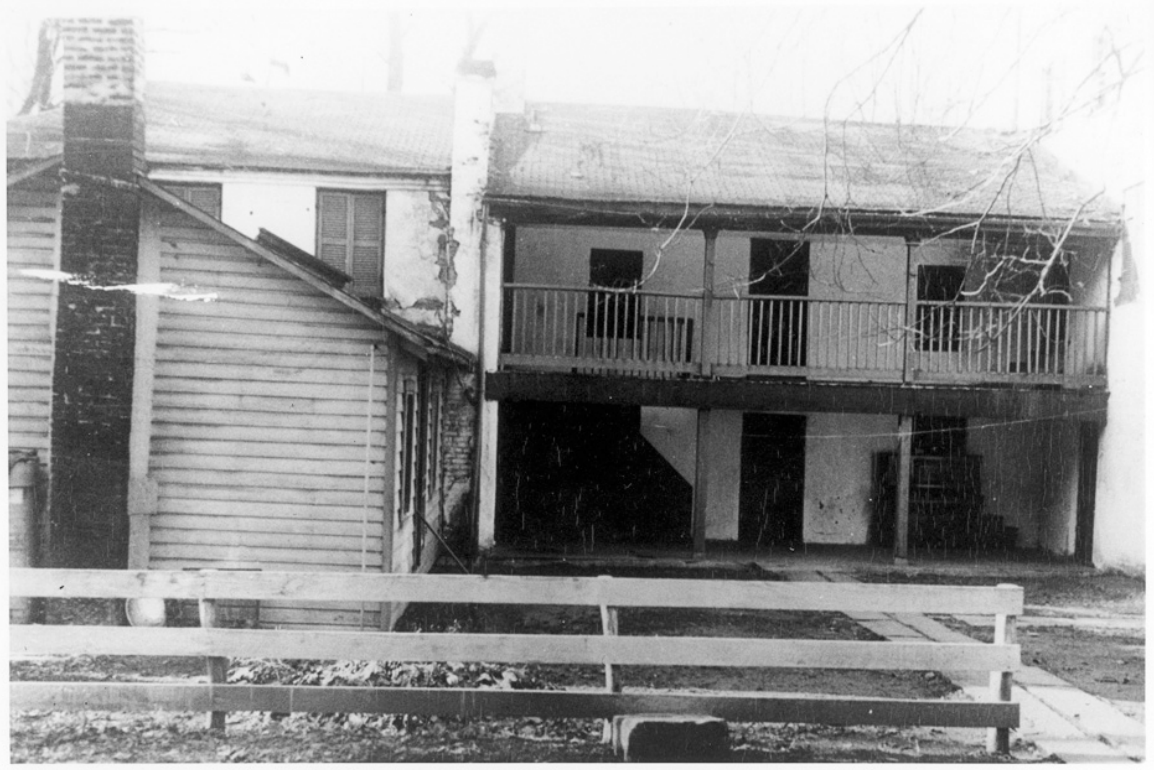

Figure 6: Great Falls Tavern photographed by John Bostrup, HABS Photographer, August 6, 1936. New Deal workers also removed the frame kitchen addition. 


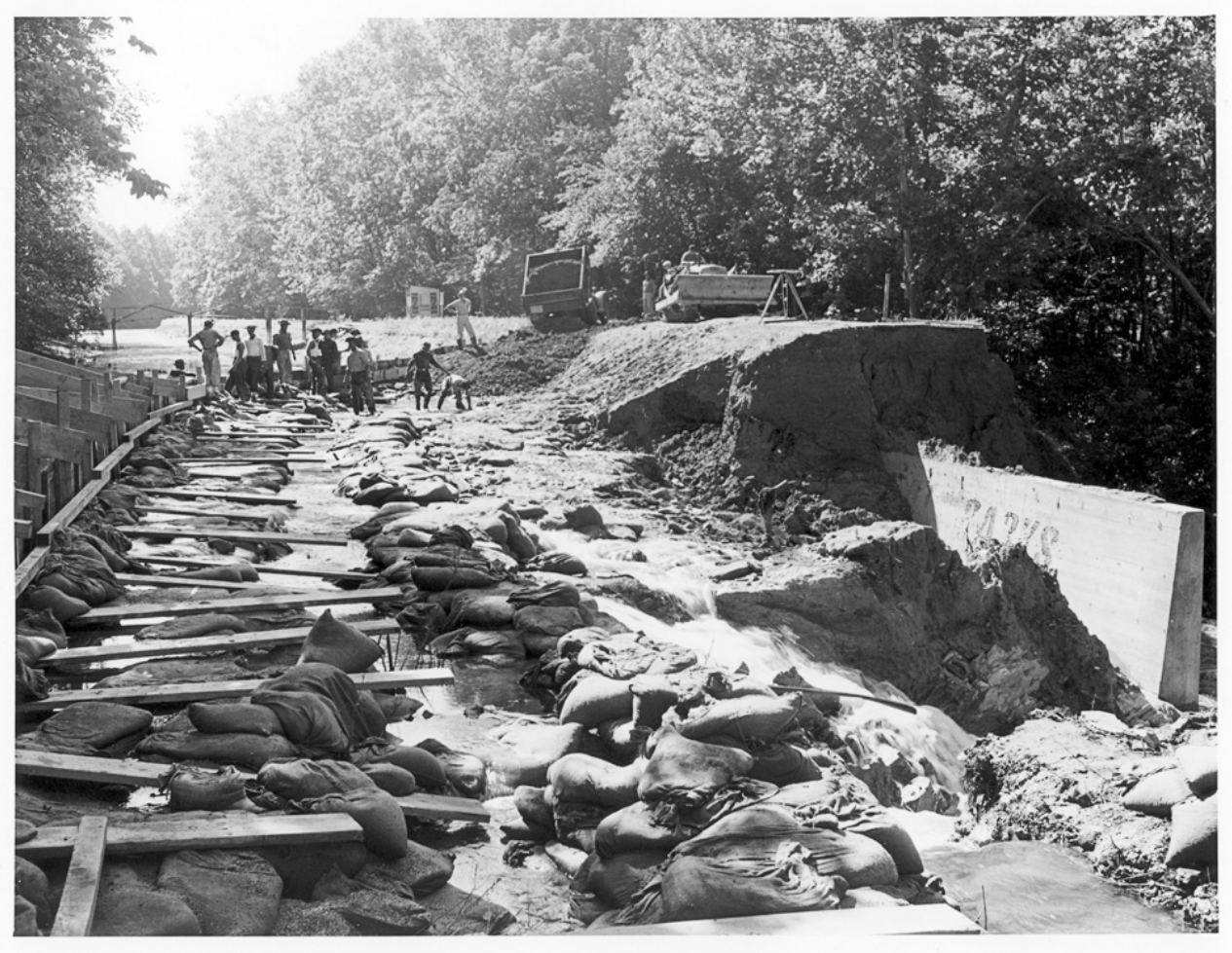

Figure 7: CCC enrollees repair towpath break

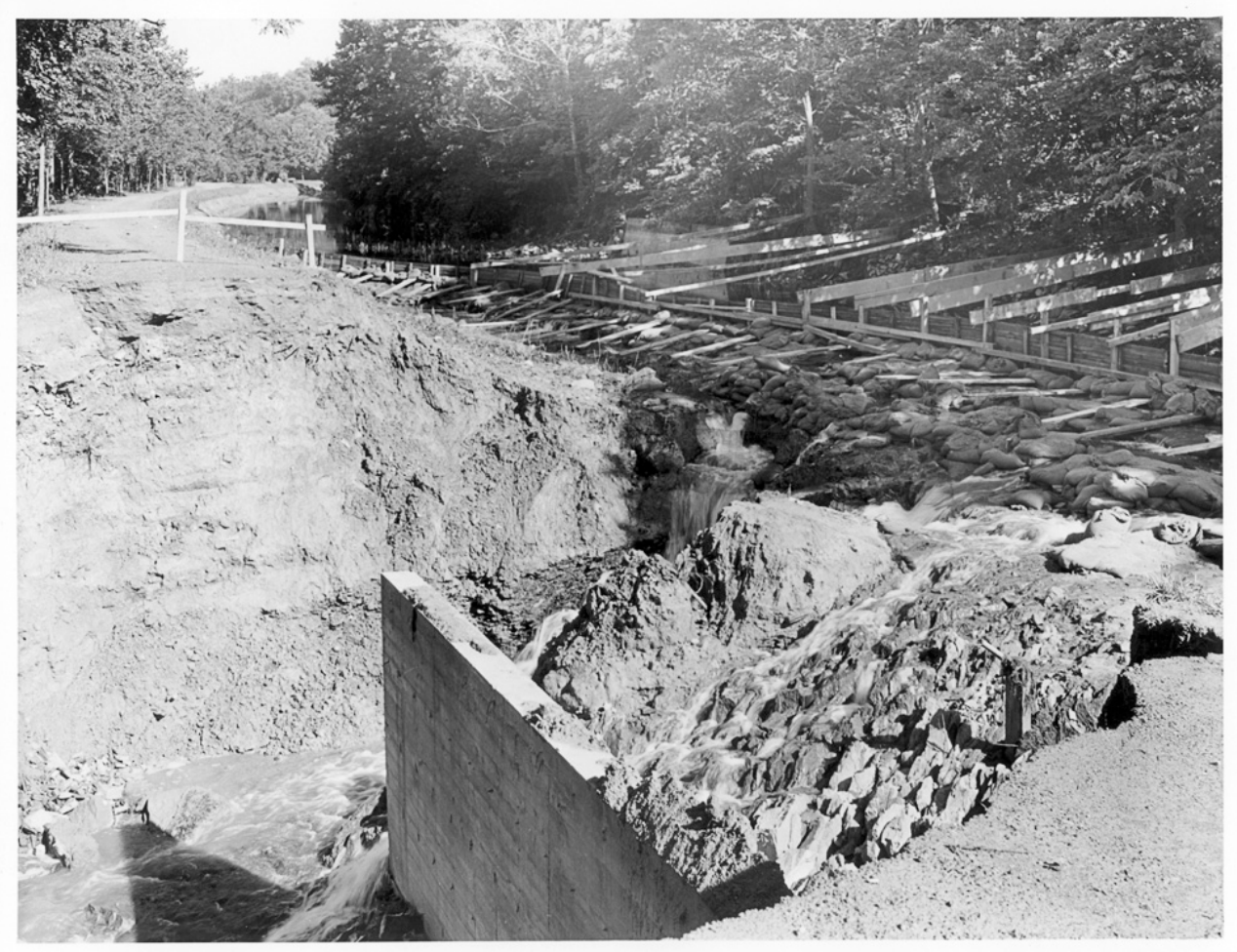

Figure 8: CCC enrollees repair towpath break 


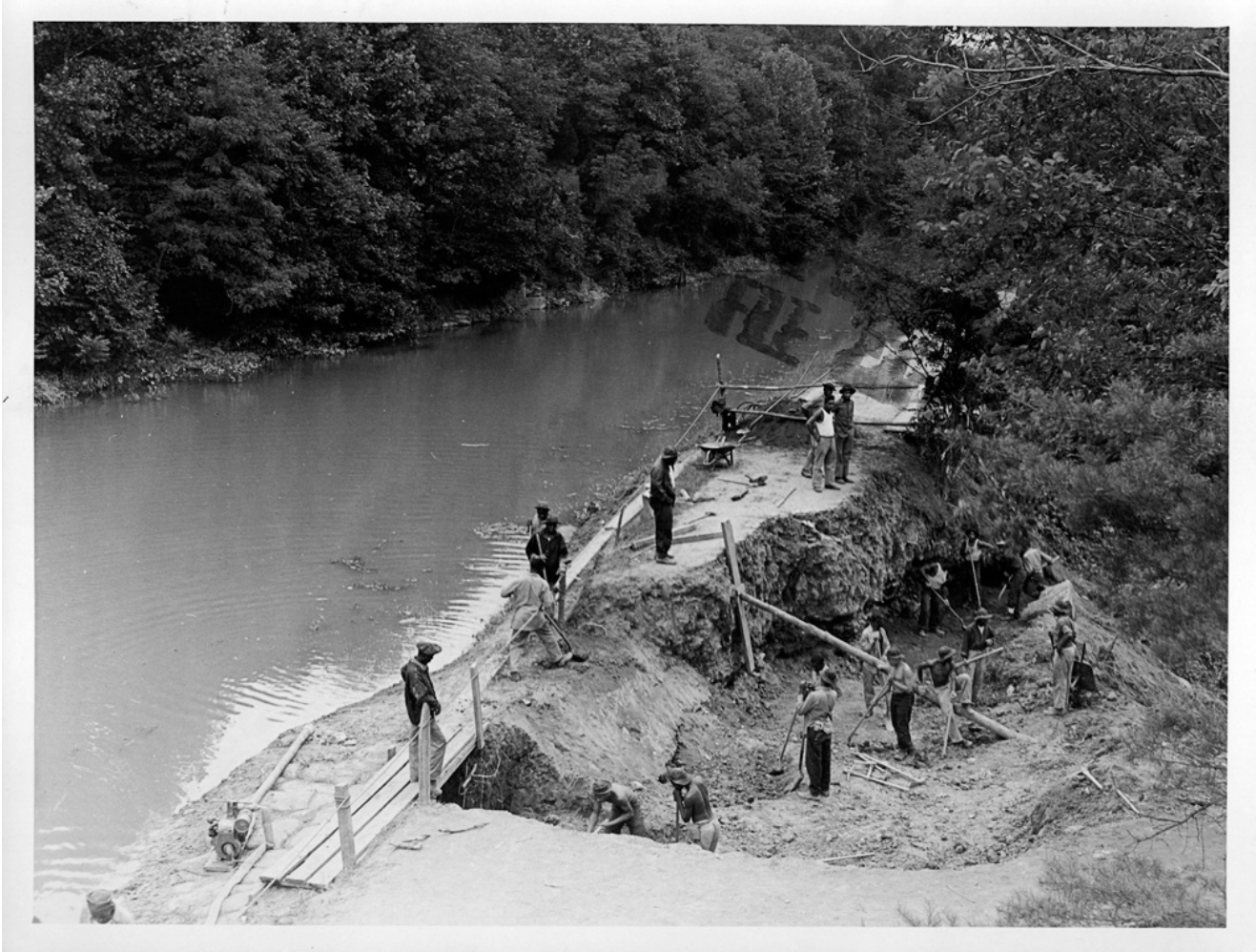

Figure 9: CCC enrollees repair towpath

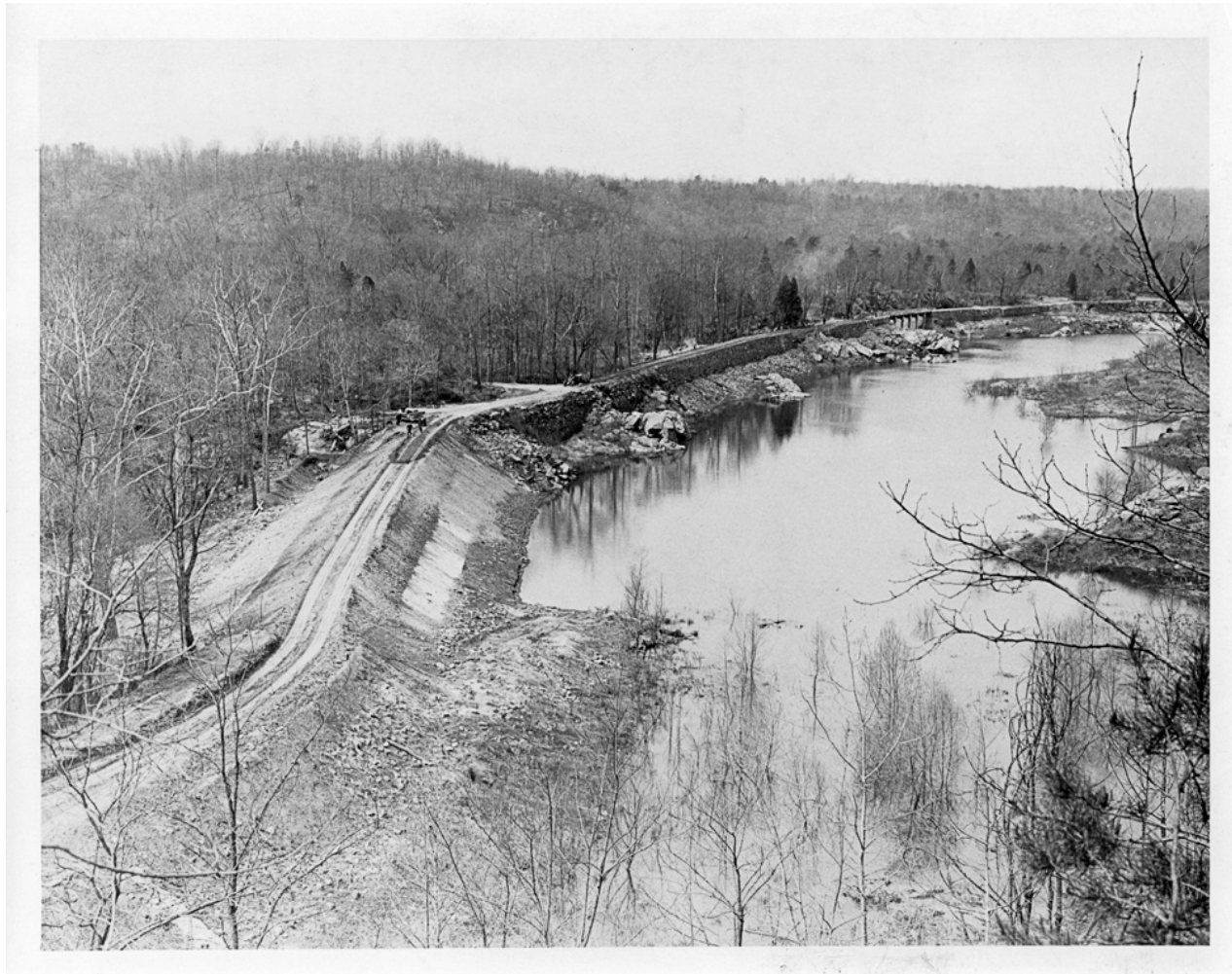

Figure 10: Widewater rehabilitation 


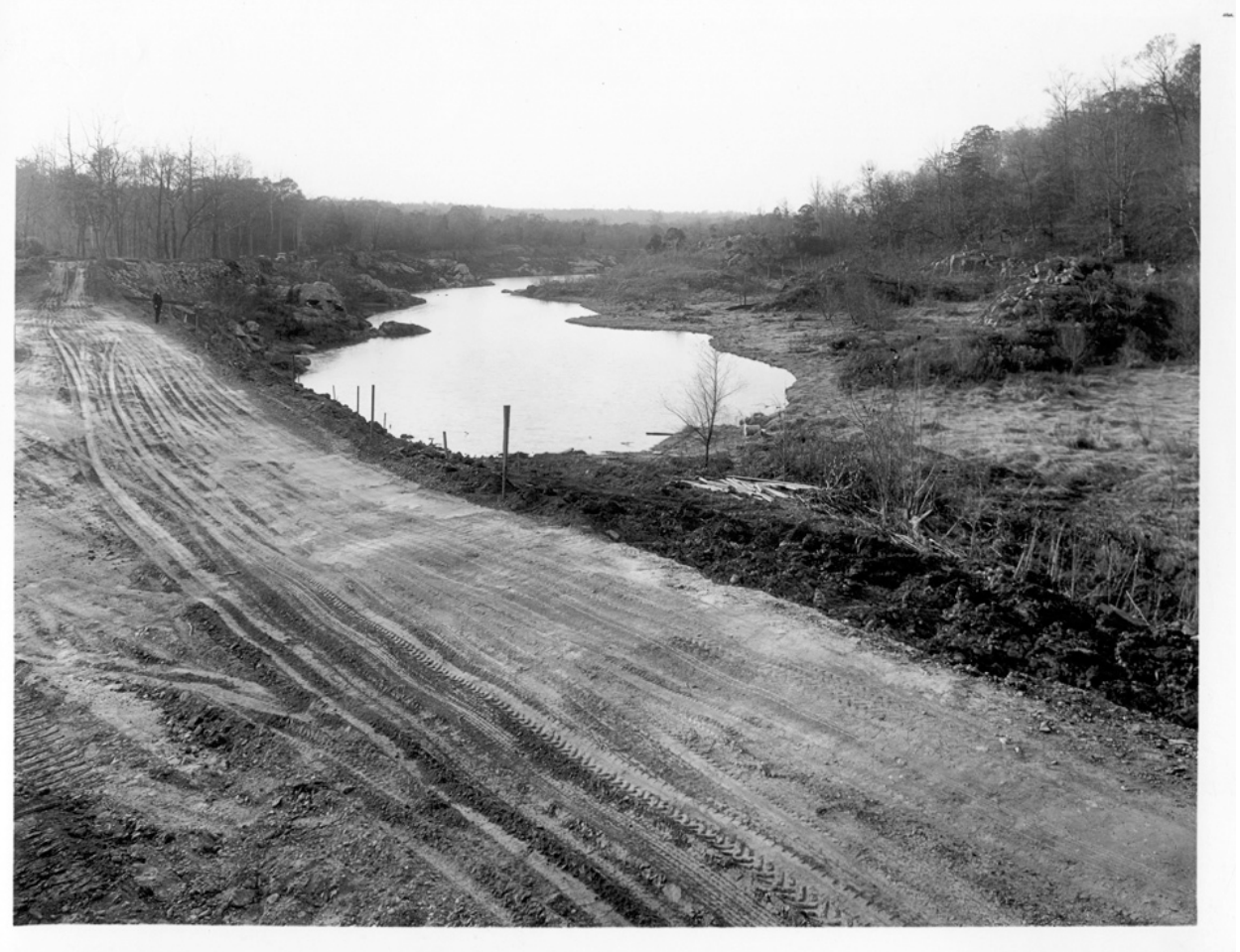

Figure 11: Widewater rehabilitation

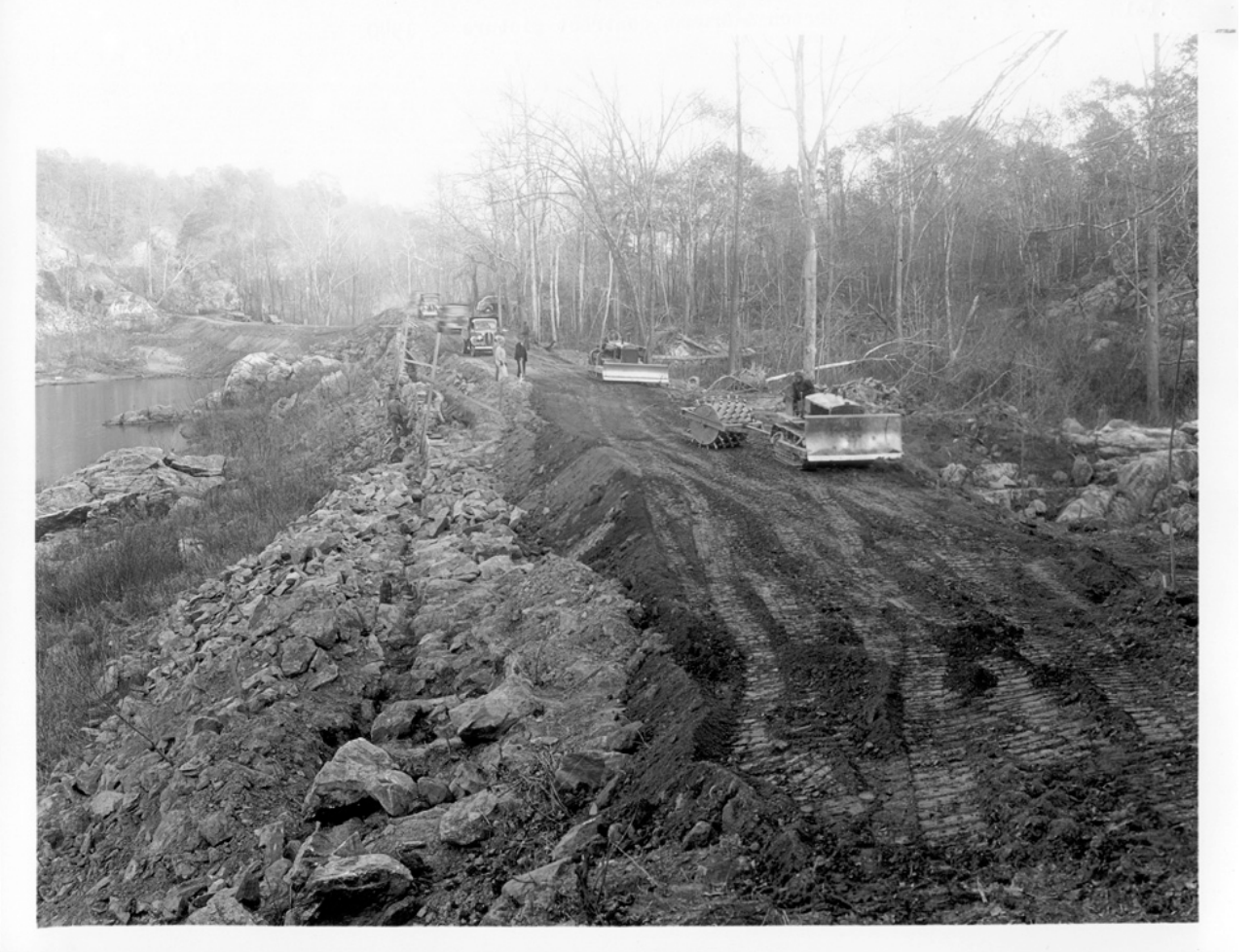

Figure 12: Widewater rehabilitation 


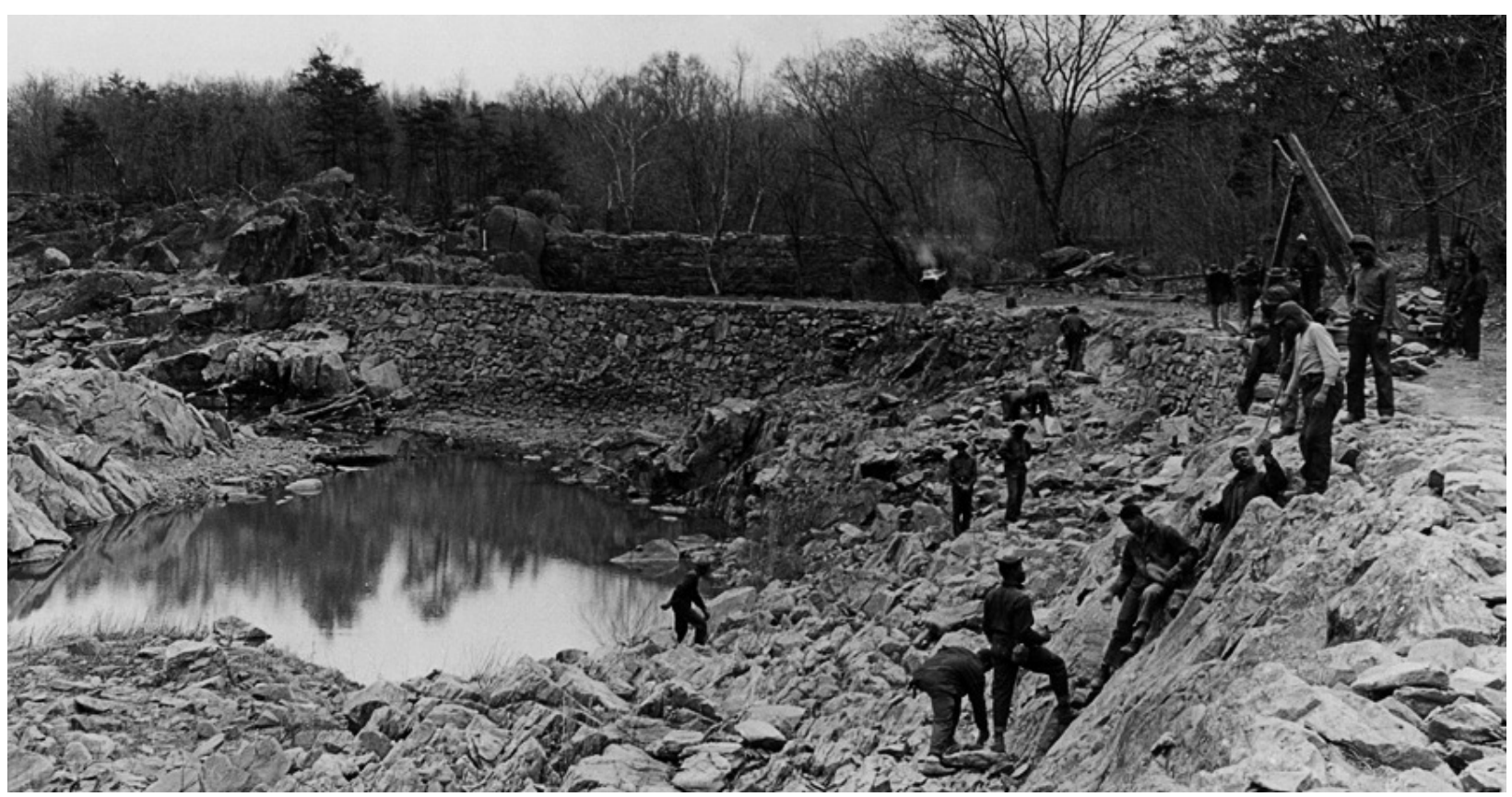

Figure 13: CCC enrollees at Widewater project area

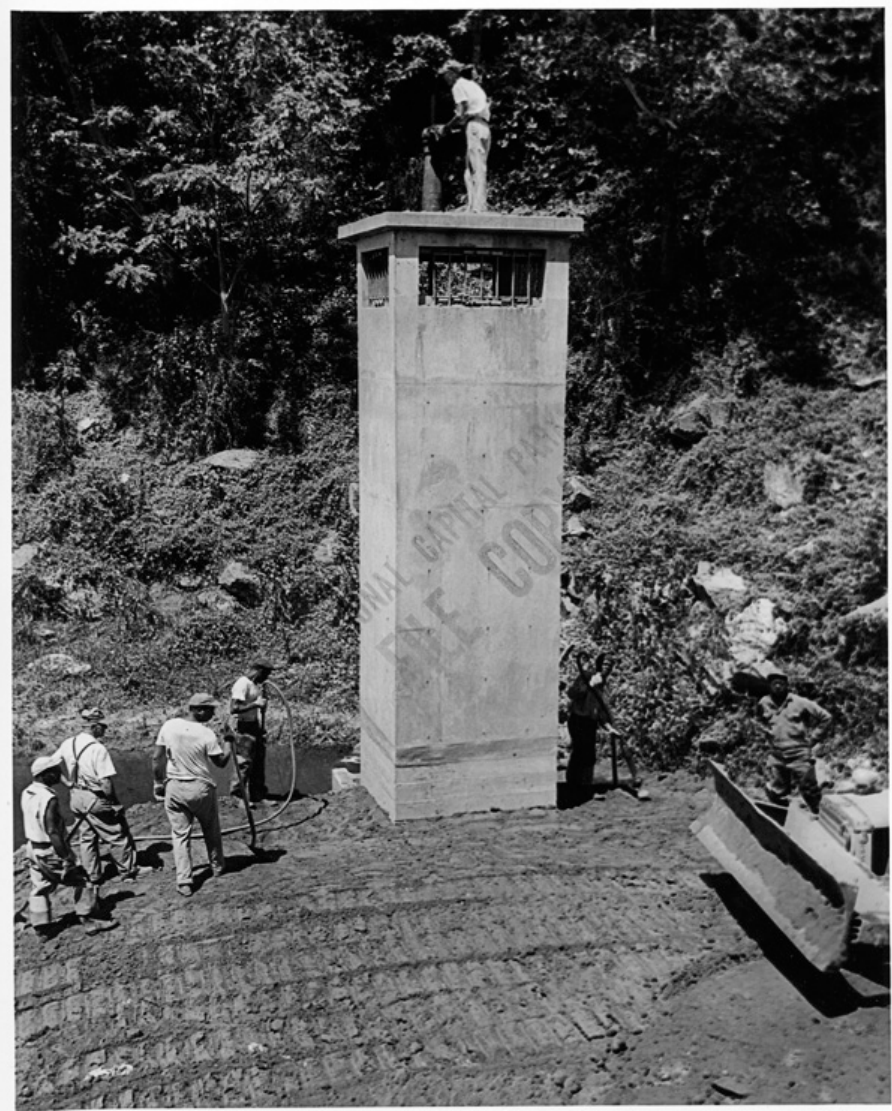

Figure 14: CCC enrollees installed flood control device in the Widewater area 


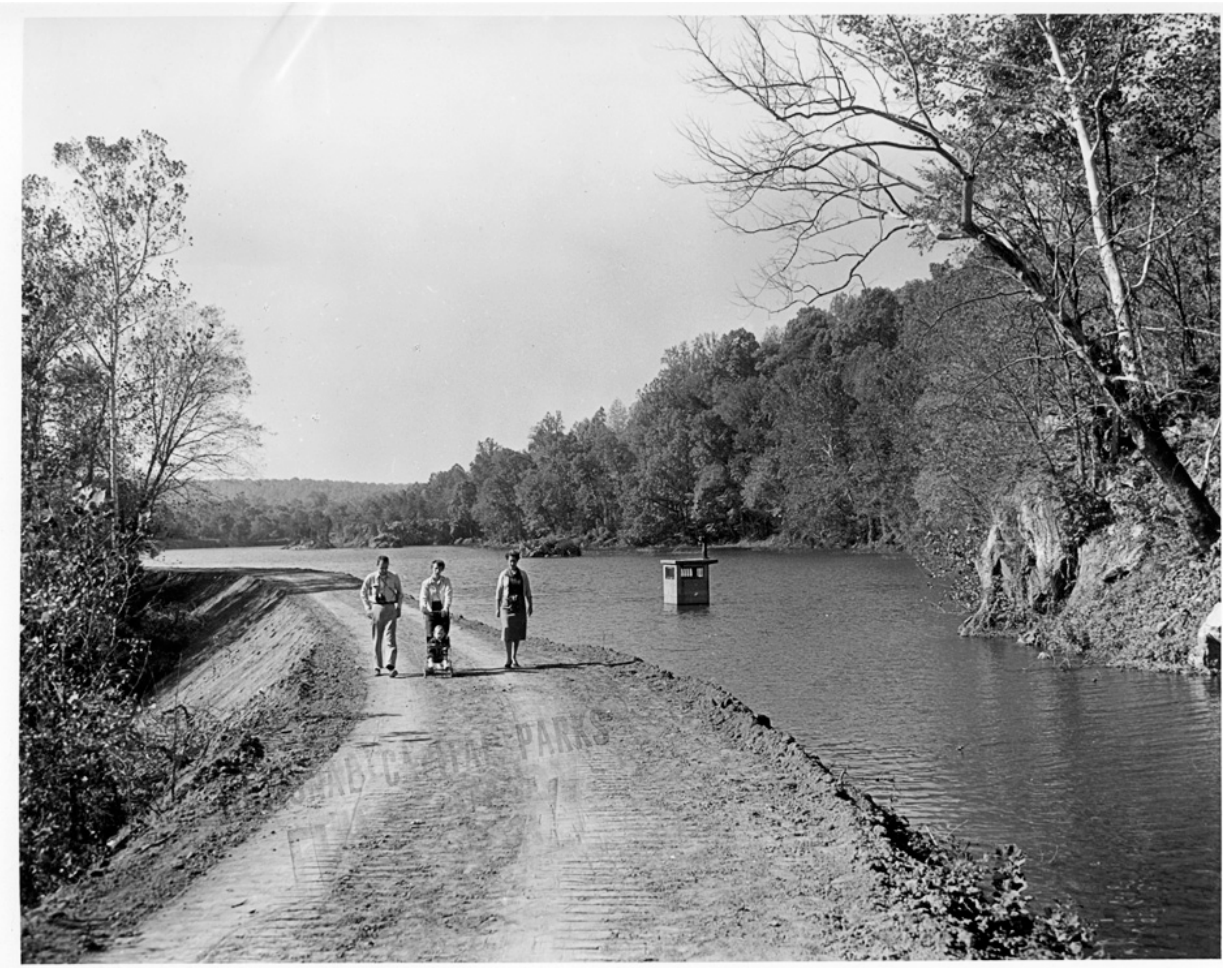

Figure 15: Widewater after completion

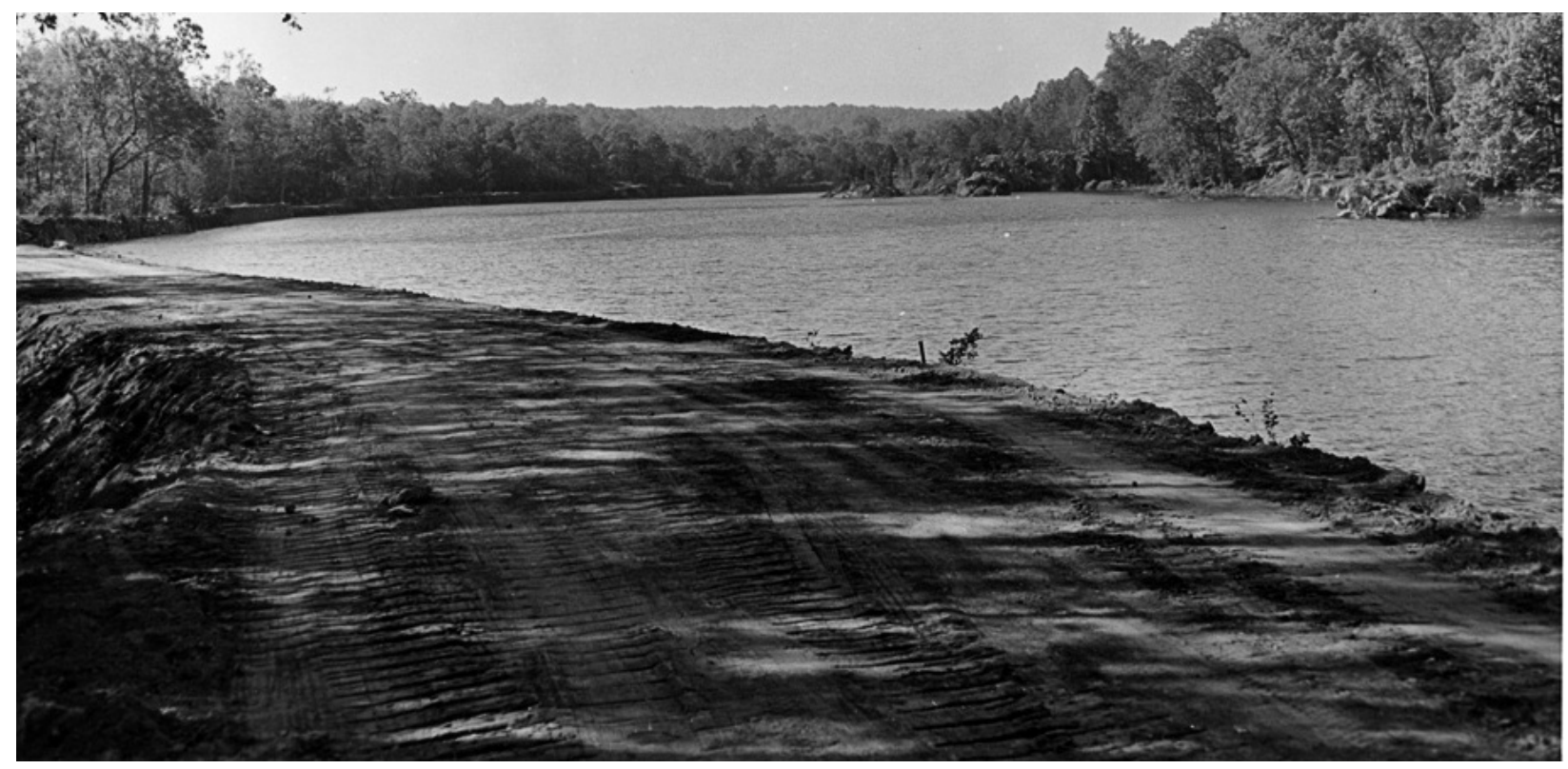

Figure 16: Widewater after completion 


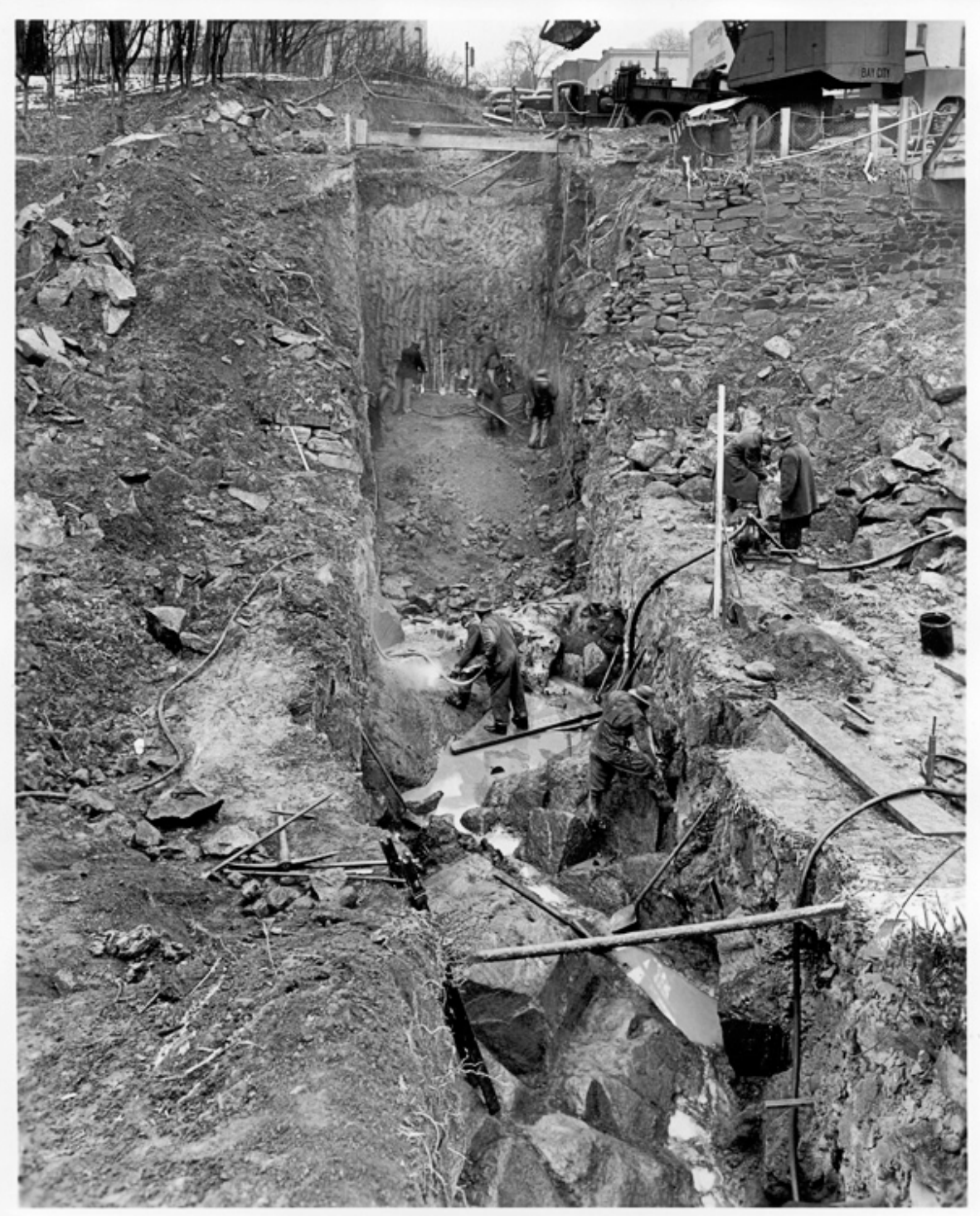

Figure 17: New Deal workers begin lock repair 


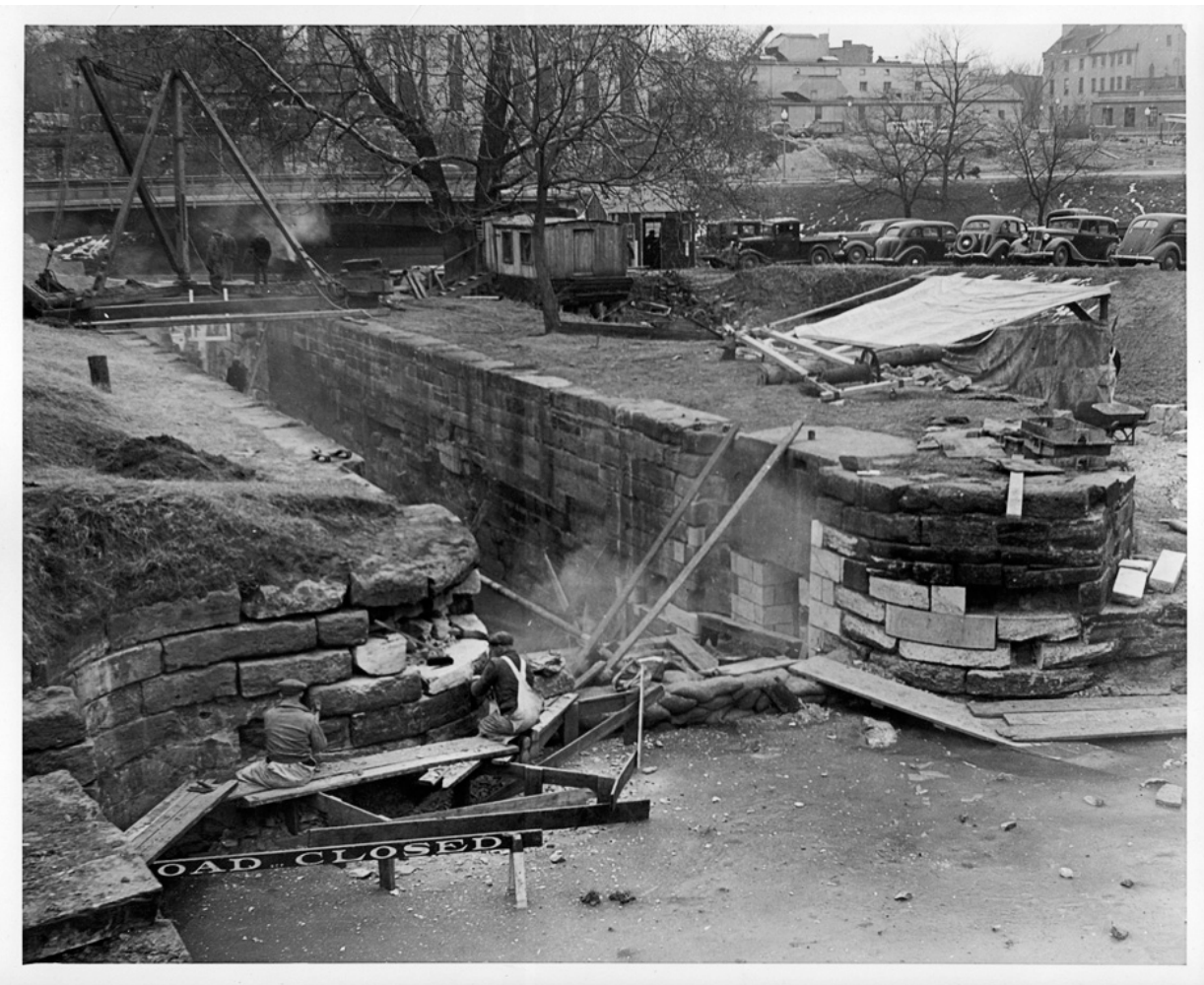

Figure 18: PWA workers rehabilitate a lock

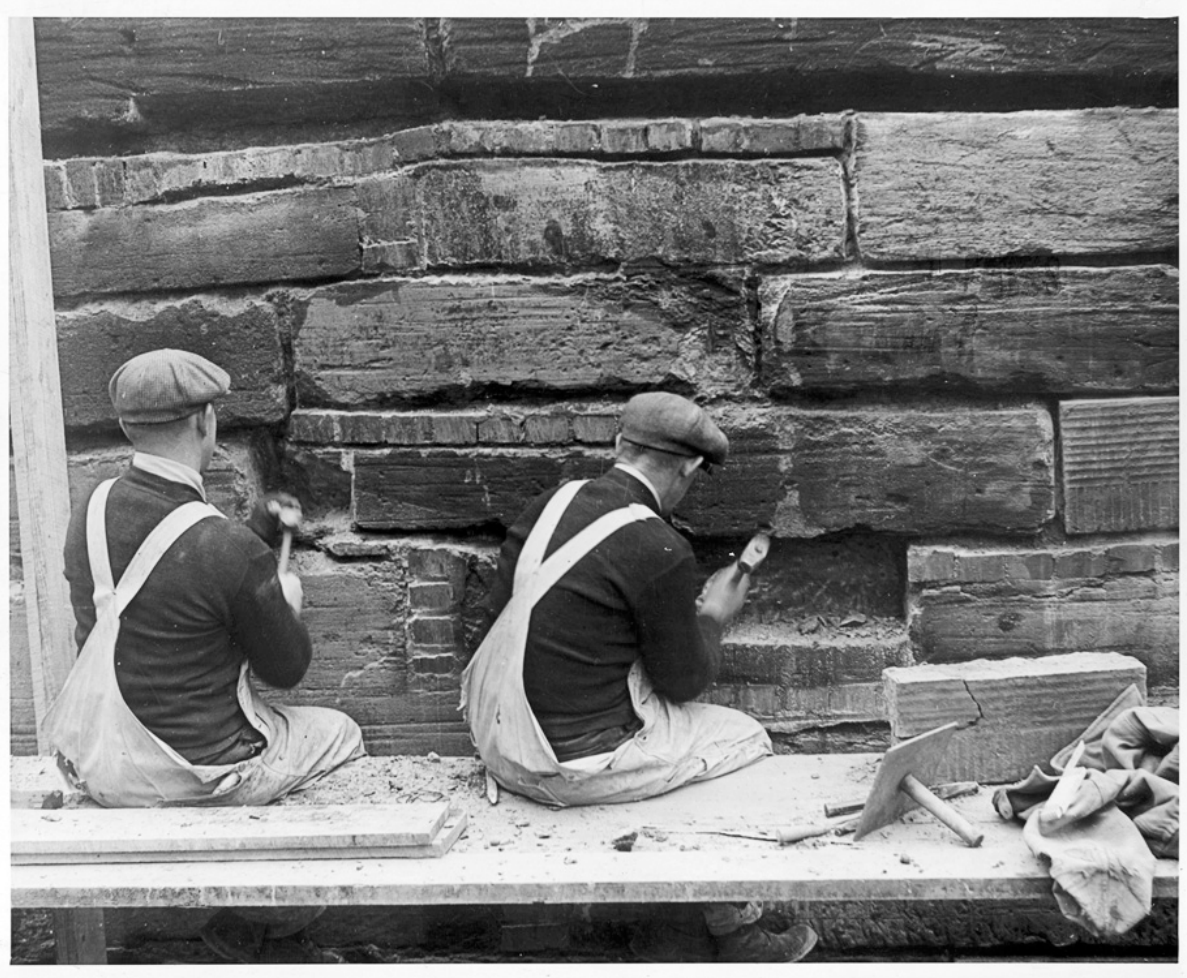

Figure 19: PWA mason repointing a lock 


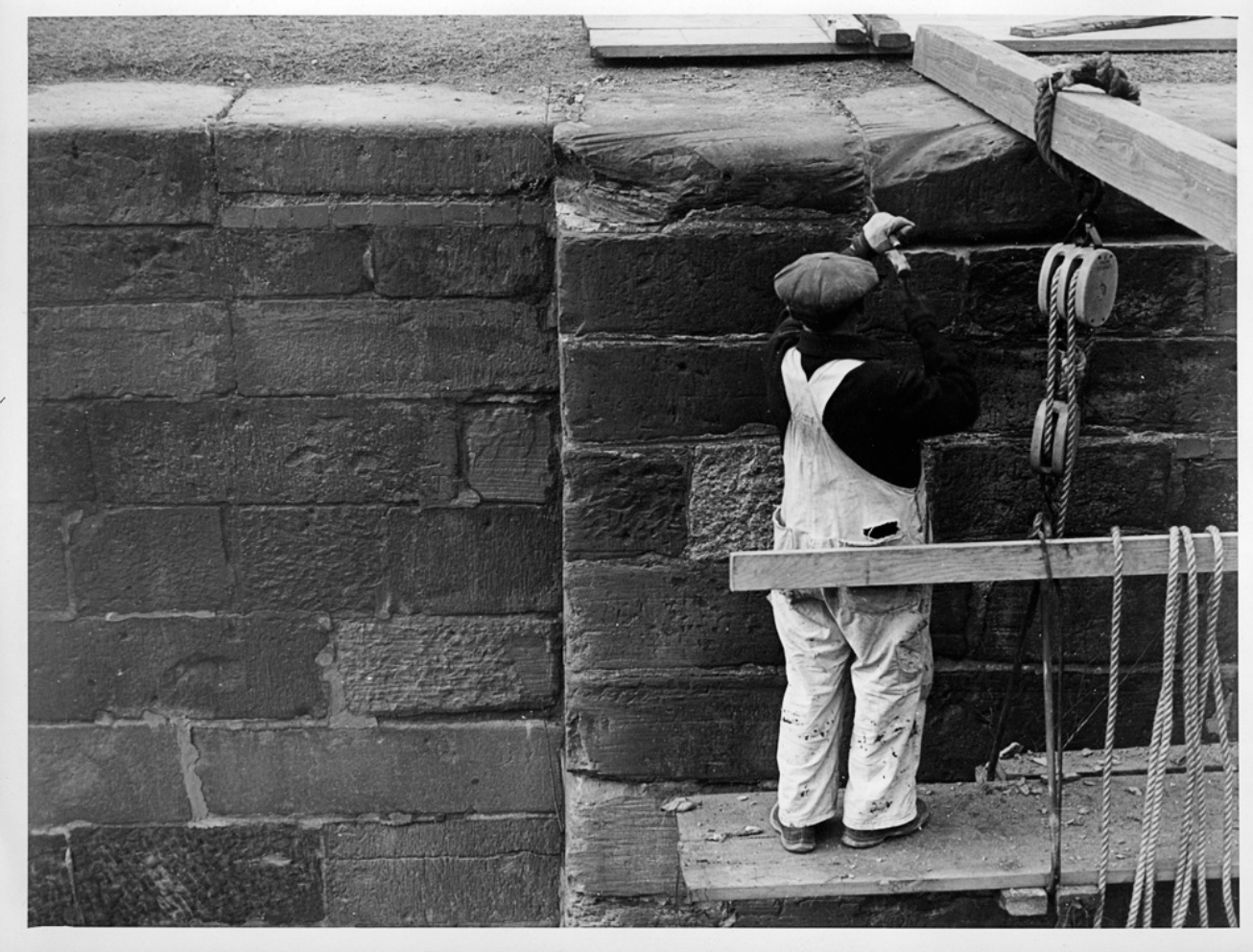

Figure 20: PWA masons repointing a lock

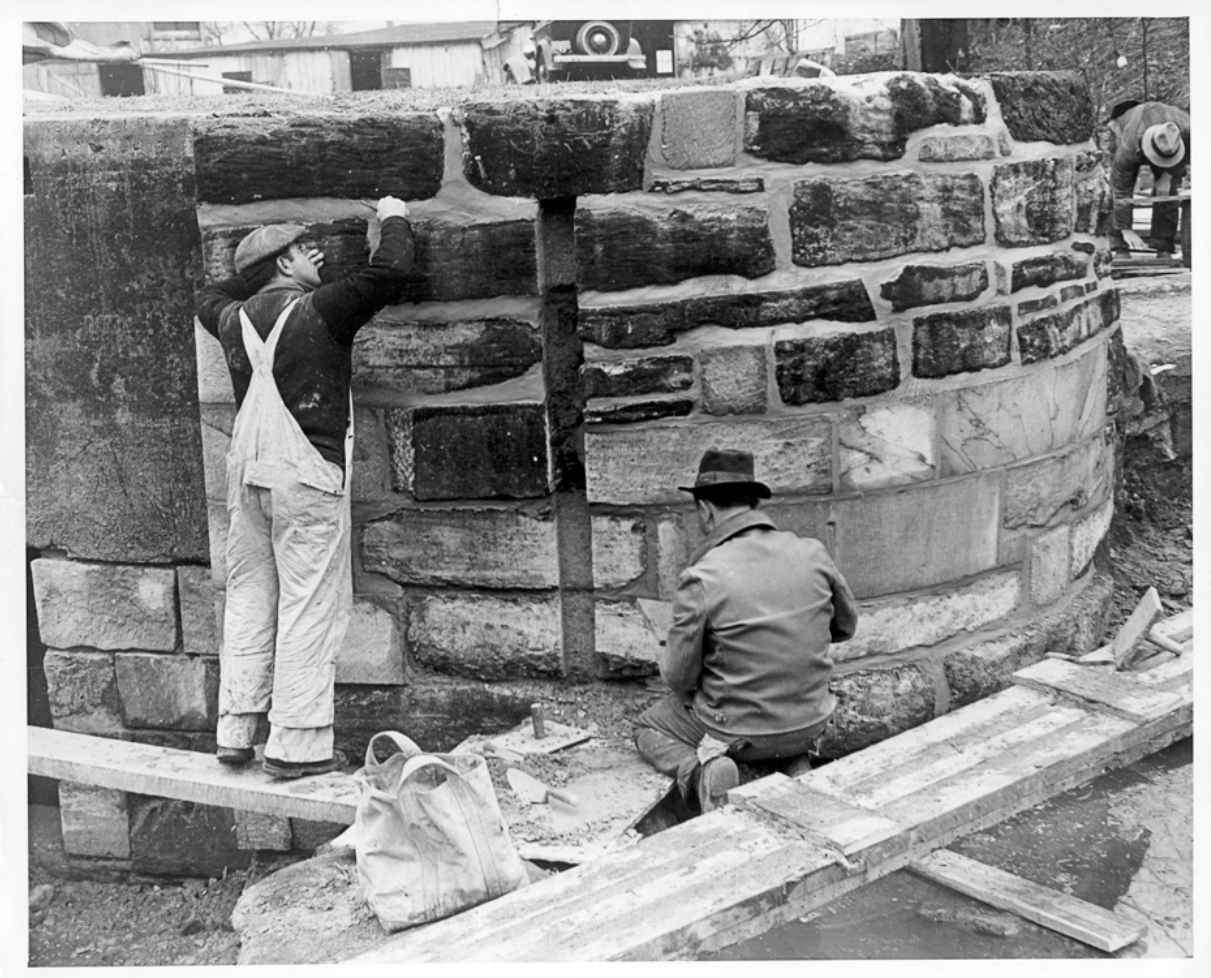

Figure 21: PWA masons repairing a lock 


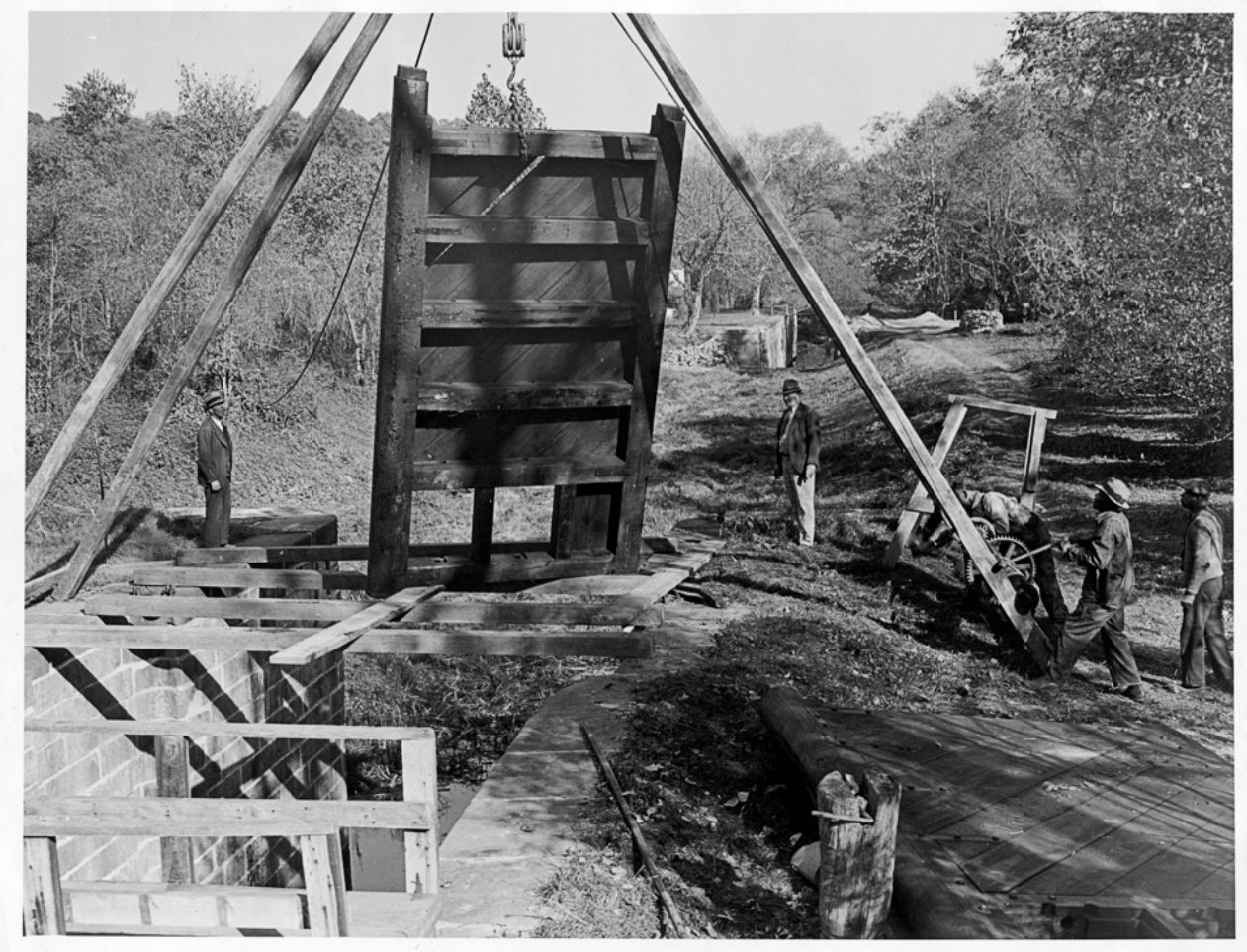

Figure 22: CCC enrollees install lock gates

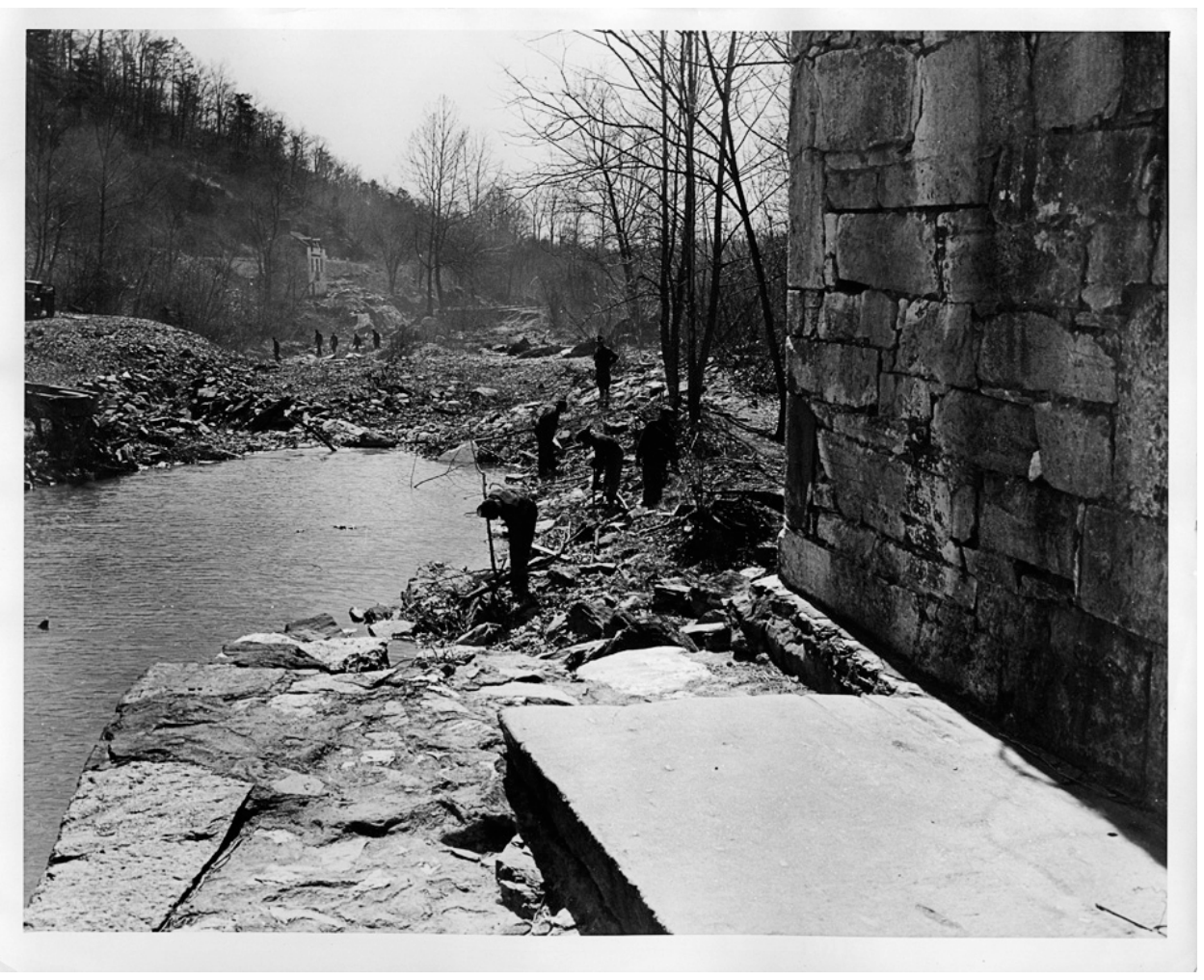

Figure 23: CCC enrollees clearing debris 


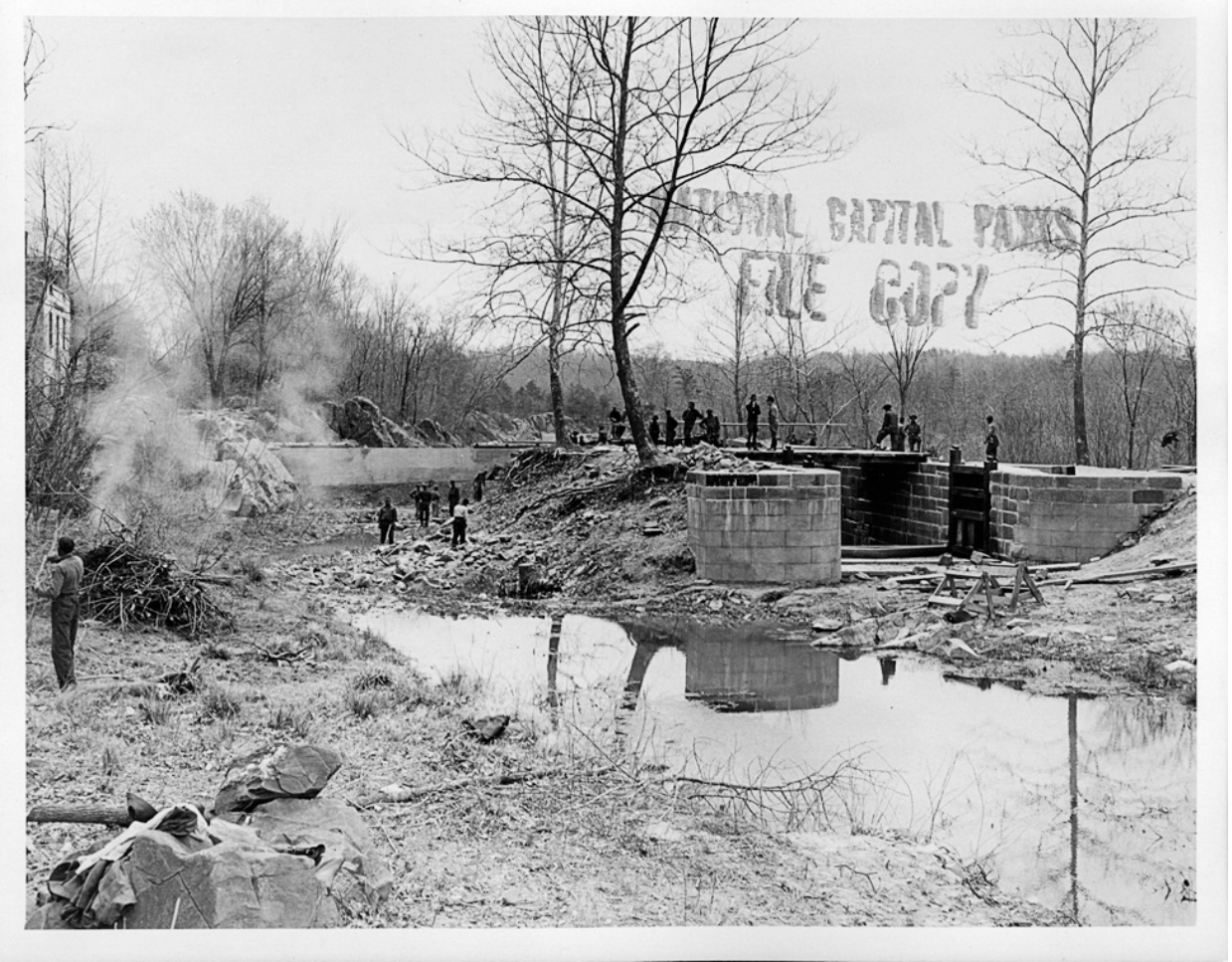

Figure 24: CCC enrollees working on lock project

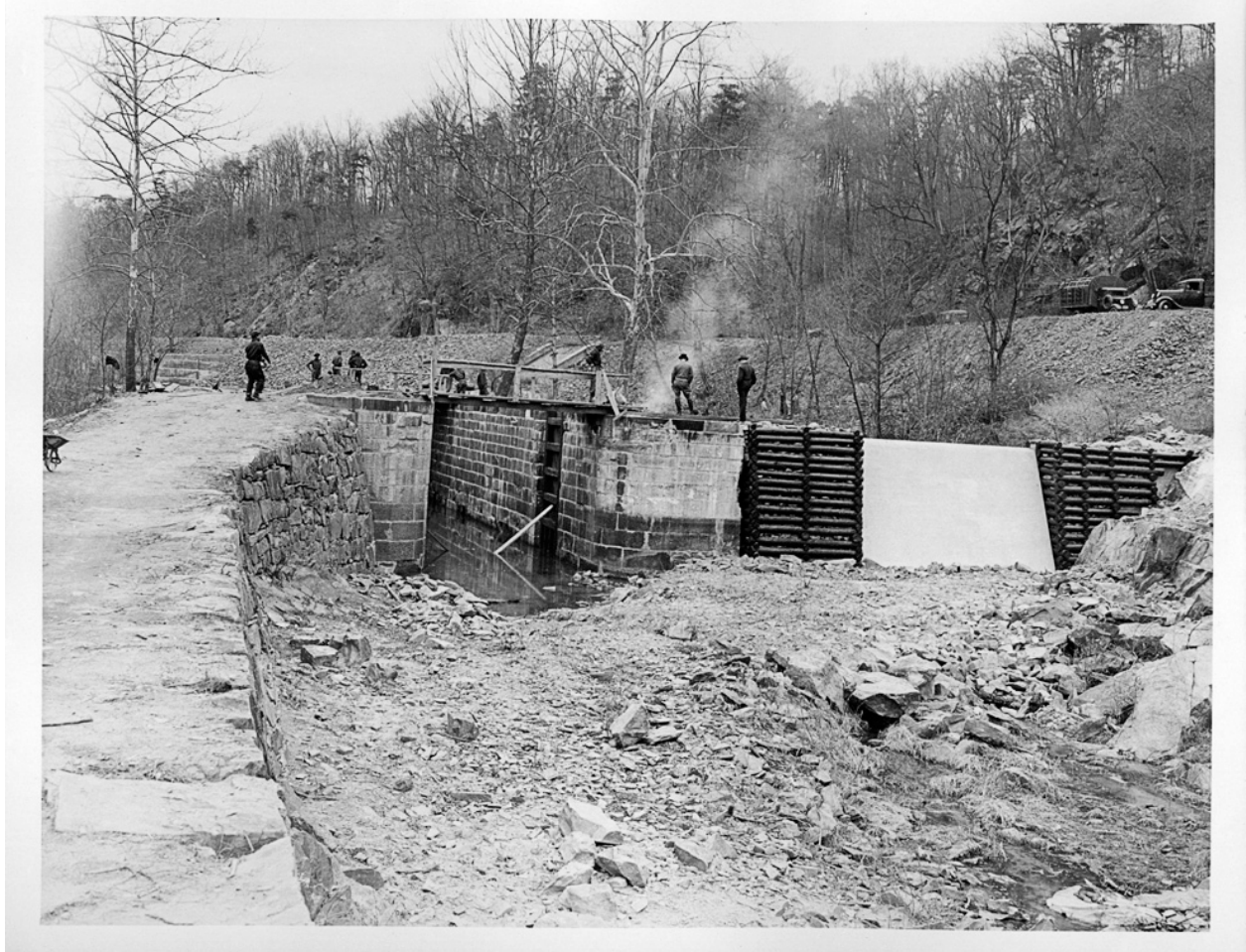

Figure 25: CCC enrollees working on bypass flume. Notice the use of concrete and stacked logs, to give it the appearance of being older. 


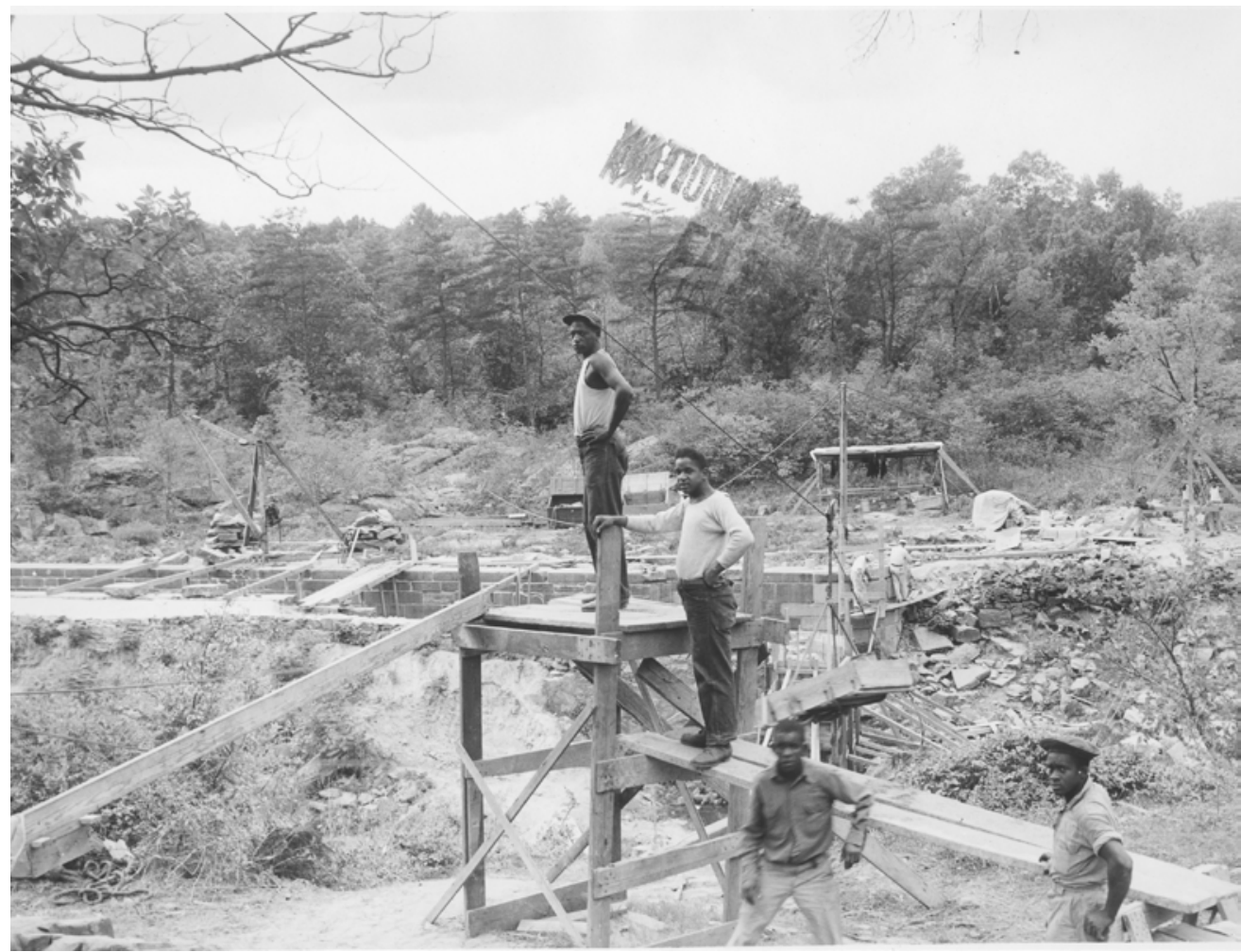

Figure 26: CCC enrollees working on a lock project

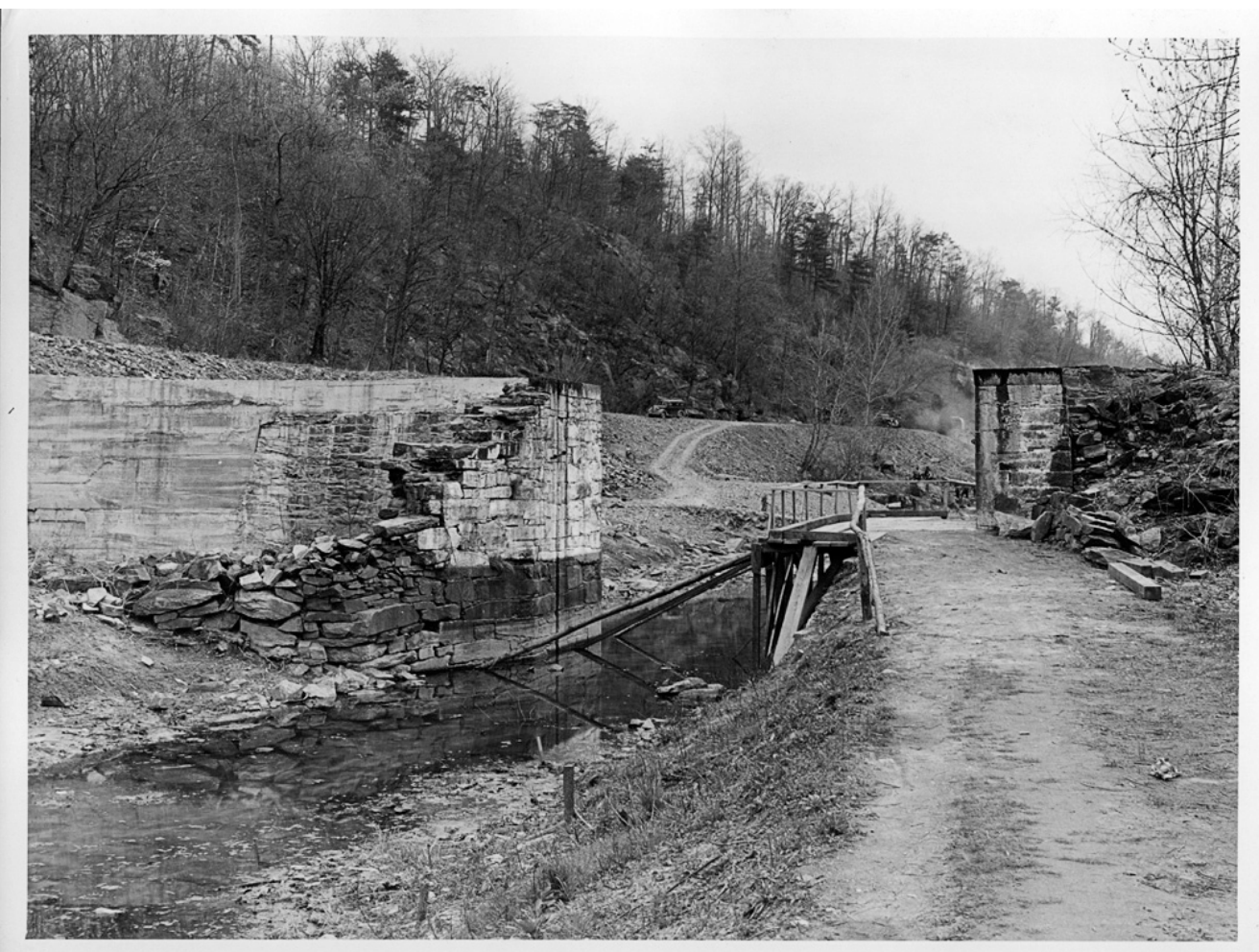

Figure 27: Stop gate rehabilitation 


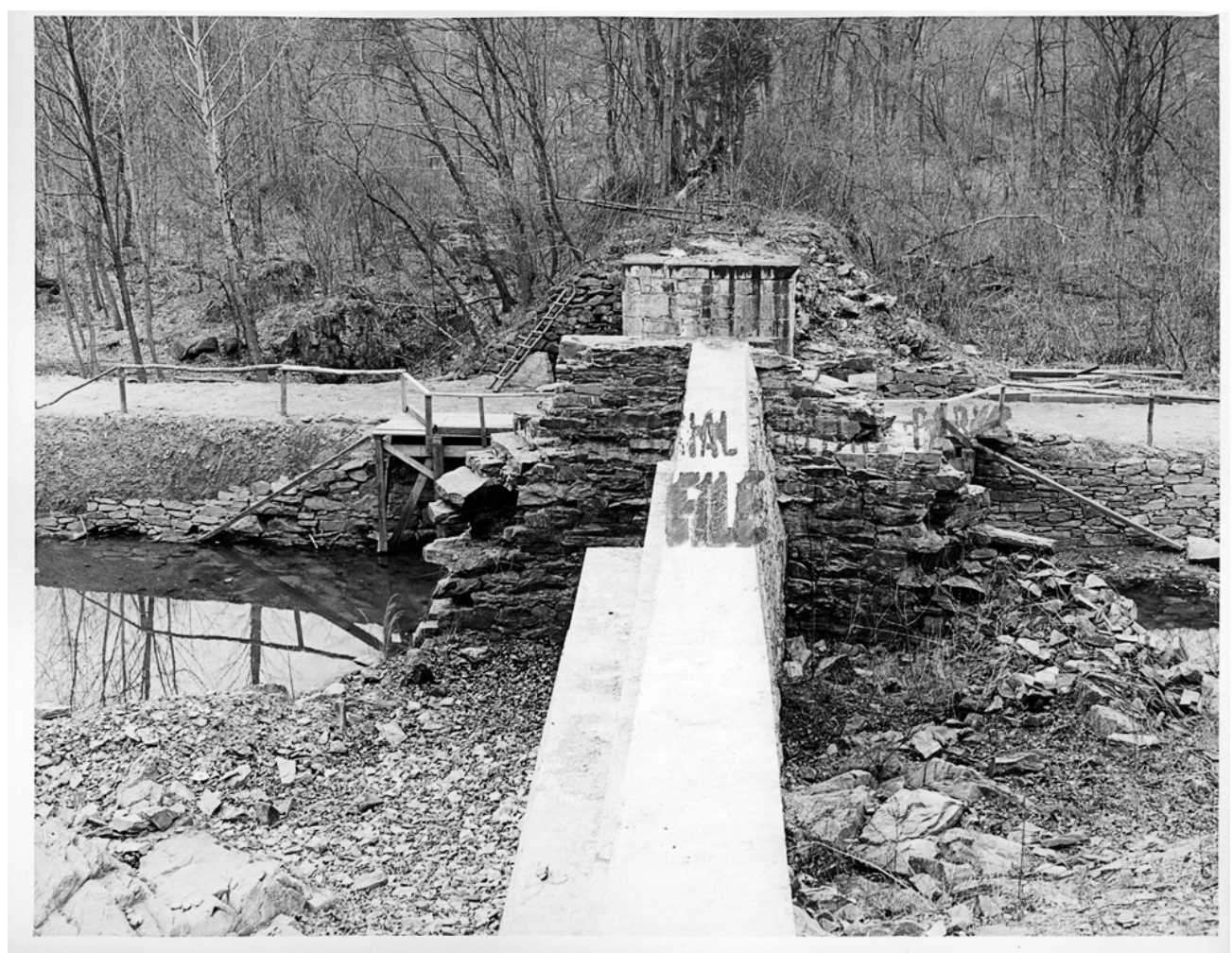

Figure 28: Stop gate rehabilitation

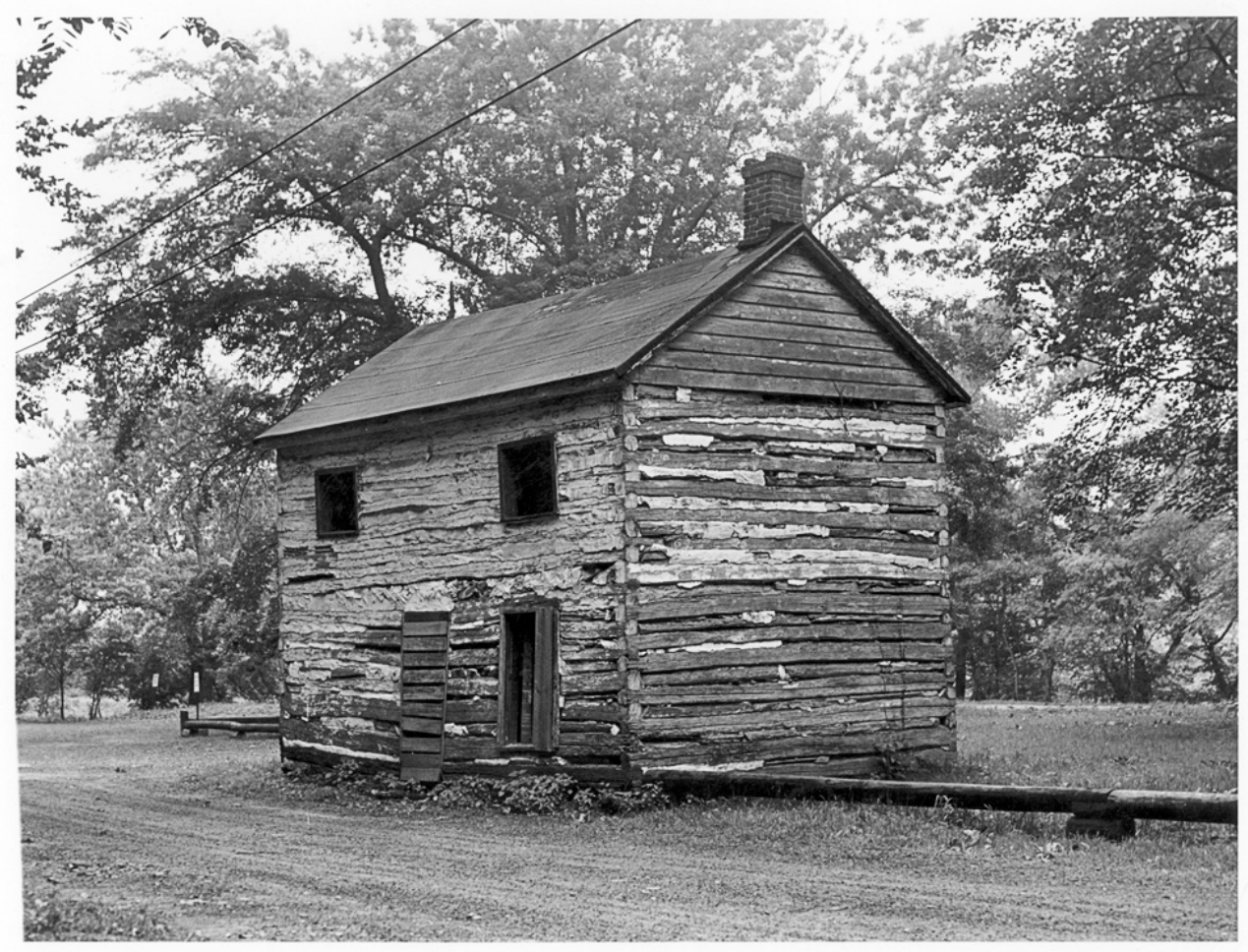

Figure 29: Log cabin at Great Falls that was later removed 


\section{BIBLIOGRAPHY}

\section{PRIMARY SOURCES}

\section{Archives Consulted}

Chesapeake and Ohio Canal National Historical Park. Clip Files.

Chesapeake and Ohio Canal National Historical Park. Historic Photographs Collection.

National Capital Region, National Park Service, Department of the Interior. Drawings 412 Series.

National Archives and Records Administration. Central Classified Files, Record Group 79, Entry10, Box 2836. Folders A-C.

National Archives and Records Administration. Central Classified Files, Record Group 79, Entry 10, Box 2837.

National Archives and Records Administration. Central Classified Files, Record Group 79, Entry10, Box 2838, “Employment” folder.

National Archives and Records Administration. National Capital Region: Subject Files, Record Group 79, Entry 149, Box 40, “1439-25 Emergency Conservation Work \#3” folder.

National Archives and Records Administration. National Capital Region: Subject Files, Record Group 79, Entry 149, Box 40, “1439-25 Emergency Conservation Work \#4” folder.

National Archives and Records Administration. National Capital Region: Subject Files, Record Group 79, Entry 149, Box 41, “1439-25-50 Personnel (Foremen, etc.) \#2” folder.

National Archives and Records Administration. National Capital Region: Subject Files, Record Group 79, Entry 149, Box 42, “1439-25-50-10 Accidents” folder.

National Archives and Records Administration. National Capital Region: Subject Files, Record Group 79, Entry 149, Box 44, "Supplies and Services, January 1937-December 1938” folder.

National Archives and Records Administration. National Capital Region: Subject Files, Record Group 79, Entry 149, Box 44, "Progress Reports” folder.

National Archives and Records Administration. National Capital Region: Subject Files, Record Group 79, Entry 149, Box 50, “1439-50 Public Works” folder. 
National Archives and Records Administration. National Capital Region: Subject Files, Record Group 79, Entry 149, Box 50, "1439-50-50 Personnel—Foremen, etc.” folder.

National Archives and Records Administration. Correspondence and Reports Relating to Surveys of Historic Sites, 1934-1964, Record Group 79, Entry 142, "Chesapeake and Ohio Canal" folder.

National Archives and Records Administration. Records Concerning Abandoned Camps, 1934 1944, Record Group 79, Entry 119, Box 2, “MD-NP-2” folder.

National Archives and Records Administration. Records Concerning WPA, 1935-1943, Record Group 79, Entry 97, Box 4, "Maryland" folder.

National Archives and Records Administration. Memos and Correspondence Concerning CCC Camps, 1935-1942, Record Group 79, Entry 118, Box 2, "DC" folder.

National Archives and Records Administration. Memos and Correspondence Concerning CCC Camps, 1935-1942, Record Group 79, Entry 118, Box 3, "Maryland" folder.

National Archives and Records Administration. Division of Investigation: Camp Inspection Reports, Record Group 35, Entry 115, Box 94, "Maryland NP-1 Montgomery County" folder.

National Archives and Records Administration. Division of Investigation: Camp Inspection Reports, Record Group 35, Entry 115, Box 94, “Maryland NP-2 Cabin John” folder.

\section{Articles}

Oxley, Howard W. "The Civilian Conservation Corps and the Education of the Negro." Journal of Negro Education 7 (1938): 375-82.

\section{Books}

Albright, Horace M. Origins of National Parks Service Administration of Historic Sites. Philadelphia: Eastern National Park \& Monument Association, 1971.

Cowan, John Pryor. Sometub's Cruise on the C\&O Canal: The Narrative of a Motorboat Vacation in the Heart of Maryland. Pittsburgh: Pittsburgh Print Co., 1916.

Dearborn, Ned H. Once in a Lifetime: A Guide to the CCC Camp. New York: Charles E. Merrill Company, 1935. 


\section{Newspaper Articles}

"Battlefields Park Measure is Signed." The Sunday Star. March 8, 1936. A-15.

"Guards on Duty in Montgomery." The Evening Star. March 22, 1936. A-3.

Noyes, Theodore. “The Flood's Challenge.” The Evening Star. March 20, 1936. A-10.

"Relief is Rushed by White House." The Evening Star. March 20, 1936. A-1.

"Rivers Go Higher with 153 Dead in U.S." The Evening Star. March 20, 1936. A-1.

“Swollen River Like Big Serpent Clutching Valley’s Landmarks.” The Evening Star. March 19, 1936. A-4.

The Towpath Journal. March 31, 1939. Vol.1.

The Towpath Journal. June 30, 1939. Vol. 2.

\section{Oral History}

Lavoie, Catherine C. "Interview with John O. Brostrup, HABS Photographer, 1936-1937.” CRM Journal 7 (2010): 16-26.

\section{Plans, Reports, and Studies}

Brown, Edgar. The CCC and Colored Youth. Washington, D.C.: United States Government Printing Office, 1941.

Civilian Conservation Corps, Official Annual 1937: District No. 3, Third Corps Area, Civilian Conservation Corps. Baton Rouge, LA: Direct Advertising Company, 1937.

Fechner, Robert. Annual Report of the Director of the Civilian Conservation Corps. Washington, D.C.: United States Government Printing Office, 1938.

Annual Report of the Director of the Civilian Conservation Corps.

Washington, D.C.: United States Government Printing Office, 1939.

Annual Report of the Director of the Civilian Conservation Corps.

Washington, D.C.: United States Government Printing Office, 1940.

Good, Albert. Park and Recreation Structures: Part II-Recreational and Cultural Facilities. Washington, D.C.: United States Government Printing Office, 1938. 
National Park Service. A Study of the Park and Recreational Problem of the United States. Washington, D.C.: United States Government Printing Office, 1941.

Vint, Thomas and Dallas D.L. McGrew. Outline Report of Architectural Work on the Restoration of the Chesapeake and Ohio Canal for Recreational Use (Georgetown, D.C., to Seneca, MD). Branch of Plans and Designs, National Park Service, Department of the Interior, 1939.

U.S. Congress, Senate, Committee on the District of Columbia. The Improvement of the Park System of the District of Columbia. Washington, D.C.: Government Printing Office, 1902. Accessed September 30, 2010, http://www.nps.gov/history/history/online books/mcmillan/plan.pdf.

Young, Rogers T. and T. Sutton Jett. A Preliminary Historical Study on the Area Along the Maryland Shore of the Potomac at Great Falls During the Heyday of the Chesapeake and Ohio Canal, 1858-1830. Hagerstown, Maryland: Chesapeake and Ohio Canal National Historical Park, June 1939.

\section{Government Documents}

"Civilian Conservation Corps, monograph by Legislative Reference Service, Library of Congress." Senate Documents $77^{\text {th }}$ Congress, $2 d$ Session, Miscellaneous. Washington DC: United States Government Printing Office, 1942.

H.R. 26, $71^{\text {st }}$ Congress; Congressional Record 71: 482.

\section{SECONDARY SOURCES}

\section{Articles}

Badger, Anthony. "The First Hundred Days and Beyond: What did the New Deal Accomplish?" The Historian's Perspective 19 (March 2009): accessed September 16, 2010, http://www.gilderlehrman.org/historynow/03 2009/historian3.php.

Burkly, Ann. "Blacks in the CCC: Successful Despite Discrimination." Proceedings and Papers of the Georgia Association of Historians 14 (1993): 37-45.

Davidson, Lisa Pfueller and Martin J. Perschler. "The Historic American Buildings Survey: During the New Deal Era: Documenting 'a Complete Resume of the Builders' Art."” CRM Journal 1 (2003): Accessed September 20, 2010, 
http://crmjournal.cr.nps.gov/04_article_sub.cfm?issue=Volume $\% 201 \% 20$ Number $\% 201 \% 20$ Fall $\% 202003 \&$ page $=1 \&$ seq $=1$.

Gower, Calvin W. "The Struggle of Blacks for Leadership Positions in the Civilian Conservation Corps: 1933-1942" The Journal of Negro History 61 (1976): 123-135.

Johnson, Charles. "The Army, the Negro and the CCC: 1933-1942." Military Affairs 36 (1972): $82-88$.

Maher, Neil. "A New Deal Politic: Landscape, Labor, and the Civilian Conservation Corps." Forest History Society and the American Society for Environmental History 7 (2002):435-461.

Patton, Thomas W. "A Forest Camp Disgrace": The Rebellion of Civilian Conservation Corps Workers at Preston, New York, July 7, 1933." New York History 82 (July 2001): 231 258.

Quigley, Barbara. "African Americans and the Civilian Conservation Corps" Traces of Indiana \& Midwestern History 17 (January 2005): 44-47.

Salmond, John A. "The Civilian Conservation Corps and the Negro." Organization of American Historians 52 (1965): 75-88.

Sirna, Angela R. "The 1886 Flood: Representations of the C\&O Canal's Golden Age." Unpublished Paper-West Virginia University, 2010.

Unrau, Harlan D. and G. Frank Williss. "To Preserve the Nation's Past: The Growth of Historic Preservation in the National Park Service in the National Park Service During the 1930s." The Public Historian 9 (1987): 19-49.

Young, T. "False, Cheap and Degraded: When History, Economy and Environment Collided at Cades Cove, Great Smoky Mountains National Park.” Journal of Historical Geography 32 (January 2006): 169-189.

\section{Books}

Birnbaum, Charles A. and Mary V. Hughes. Design with Culture: Claiming America's Landscape Heritage. Charlottesville: University of Virginia Press, 2005.

Cole, Olen. The African-American Experience in the Civilian Conservation Corps. Gainesville: University Press of Florida, 1999. 
Cornebise, Alfred Emile. The CCC Chronicles: Camp Newspapers of the Civilian Conservation Corps, 1933-1942. Jefferson, North Carolina: McFarland \& Company, 2004.

Cremin, Dennis, and Charlene Giardina. Starved Rock State Park: The Work of the CCC along the I\&M Canal. Images of America. Chicago, IL: Arcadia Publishing, 2002.

Cronon, William. Changes in the Land: Indians, Colonists, and the Ecology of New England. New York: Hill and Wang, 2003.

Cutler, Phoebe. The Public Landscape of the New Deal. New Haven: Yale University Press, II 1985.

Davidson, James West and Mark Hamilton Lytle. "The View from the Bottom Rail" in After the Fact: The Art of Historical Detection, 177-209. Boston: McGraw Hill, 2005.

Dunn, Durwood. Cades Cove: The Life and Death of an Appalachian Community, 1818-1937. Knoxville: University of Tennessee Press, 1988.

Jackson, John Brinckerhoff. The Necessity for Ruins and Other Topics. Amherst: University of Massachusetts Press, 1980.

Lacy, Leslie Alexander. The Soil Soldiers: The Civilian Conservation Corps in the Great Depression. Radnor, Pennsylvania: Chilton Book Company, 1976.

Herbert, David. T. Heritage, Tourism, and Society. London: Mansell Publishing, 1995.

Himmelberg, Robert F. The Great Depression and the New Deal. Westport, Connecticut: Greenwood Press, 2001.

Hosmer, Charles B. Presence of the Past: A History of the Preservation Movement in the United States Before Williamsburg. New York: G.P. Putnam's Sons, 1965.

Mackintosh, Barry. C\&O Canal: The Making of a Park. Washington, D.C.: Department of the Interior, National Park Service, 1991.

Interpretation in the National Park Service: A Historical Perspective. Washington, D.C.: Department of the Interior, National Park Service, 1983. Accessed February 26, 2011. http://www.cr.nps.gov/history/online books/mackintosh2/.

The National Parks: Shaping the System. Washington, D.C.: Department of the Interior, National Park Service, 1991.

Maher, Neil. Nature's New Deal: The Civilian Conservation Corps and the Roots of the American Environmental Movement. Oxford: Oxford University Press, 2008.

Marx, Leo. The Machine in the Garden. Oxford: Oxford University Press, 2004. 
Merill, Perry H. Roosevelt's Forest Army: A History of the Civilian Conservation Corps, 1933 1942. Montpelier: Perry H. Merrill, 1981.

Norkunas, Martha. The Politics of Public Memory: Tourism, History, and Ethnicity in Monterey, California. Albany: State University of New York Press, 1993.

National Park Service. Secretary of the Interior's Standards for the Treatment of Historic Properties with Guidelines for Preserving, Rehabilitating, Restoring, and Reconstructing Historic Buildings. Washington, D.C.: National Park Service, 1992.

Olson, James S. Historical Dictionary of the New Deal: From Inauguration to Preparation for War. Westport, Connecticut: Greenwood Press, 1985.

Owen, A.L. Riesch. Conservation Under F.D.R. New York: Prager Publishers, 1983.

Paige, John C. The Civilian Conservation Corps and the National Park Service, 1933-1942: An Administrative History. Washington, D.C.: Department of the Interior, National Park Service, 1985.

Salmond, John A. The Civilian Conservation Corps, 1933-1942: A New Deal Case Study. Durham, North Carolina: Duke University Press, 1967: accessed June 28, 2010, www.nps.gov/history/history/online books/ccc/salmond.

Sanderlin, Walter. The Great National Project: A History of the C\&O Canal (Baltimore: John Hopkins Press, 1946).

Schama, Simon. Landscape and Memory. New York: Alfred A. Knopf, 1995.

Shaffer, Marguerite S. See America First: Tourism and National Identity, 1880-1940. Washington: Smithsonian Institution Press, 2001.

Sitkoff, Harvard. A New Deal for Blacks: The Emergence of Civil Rights as a National Issue The Depression Decade. Oxford: Oxford University Press, 2009.

Sontag, William H. National Park Service: The First 75 Years. Philadelphia: Eastern National Park and Monument Association, 1990.

Sowards, Adam. The Environmental Justice: William O. Douglas and American Conservation. Corvallis: Oregon University Press, 2009.

Speakman, Joseph M. At Work in Penn's Woods: The Civilian Conservation Corps in Pennsylvania. University Park, Pennsylvania: The Pennsylvania State University Press, 2006.

Stanton, Cathy. The Lowell Experiment: Public History in a Postindustrial City. Amherst: University of Massachusetts Press, 2006. 
Unrau, Harland D. and G. Frank Williss. Expansion of the National Park Service in the 1930s: An Administrative History. Denver: Department of the Interior, National Park Service, 1983. Accessed September 17, 2010,

http://www.cr.nps.gov/history/online books/unrauwilliss/adhi.htm

Walker, Melissa. All We Knew was to Farm: Rural Women in the Upcountry South, 1919 1941.Baltimore: The Johns Hopkins University Press, 2000.

West, Patricia. Domesticating History: The Political Origins of America's House Museums. Washington, D.C.: Smithsonian Institution Press, 1999.

\section{Theses and Dissertations}

Hoak, Michael. "The Men in Green: African Americans and the Civilian Conservation Corps, 1933-1942." Thesis—College of William and Mary, 2002.

Meringolo, Denise. "Turning Nature into History: The Professionalization of Public History in the National Park Service During the 1930s." Dissertation-George Washington University, 2005.

\section{Other}

“American Place: The Historic American Buildings Survey at Seventy-Years," Historic American Building Survey Exhibit Catalog, 2008.

"A Short Biography of Edgar H. Pickering," Maryland State Archives, last modified July 22, 1997, accessed October 18, 2010, http://www.msa.md.gov/msa/speccol/photos/html/pickring.html.

Davidson, L.P. and J. A. Jacobs. "Civilian Conservation Corps Activities in the National Capital Region of the National Park Service". Washington, D.C.: Department of the Interior, Historic American Building Survey, 2005.

Grassick, Mary. "Great Falls Tavern: Historic Furnishings Report.” Harpers Ferry Center. Hagerstown, Maryland: National Park Service, June 2008.

"Great Falls Tavern Cultural Landscape Report." National Capital Region Cultural Landscapes Program. Washington, D.C.: National Park Service, September 2009.

"History of the Civilian Conservation Corps-And its Lasting Legacy," Edinburg, Virginia: Civilian Conservation Corps Legacy Inc., 2010. 
"The History of the Club," Washington Canoe Club, accessed October 12, 2010, http://www.washingtoncanoeclub.org/History/.

"The History of the Washington Biologists' Field Club on Plummers Island," Washington Biologists' Field Club, accessed October 12, 2010, http://www.pwrc.usgs.gov/resshow/perry/bios/History.htm. 